NBER WORKING PAPER SERIES

\title{
WOMEN, WAR AND WAGES: \\ THE EFFECT OF FEMALE LABOR SUPPLY ON \\ THE WAGE STRUCTURE AT MID-CENTURY
}

\author{
Daron Acemoglu \\ David H. Autor \\ David Lyle
}

\author{
Working Paper 9013 \\ http://www.nber.org/papers/w9013 \\ NATIONAL BUREAU OF ECONOMIC RESEARCH \\ 1050 Massachusetts Avenue \\ Cambridge, MA 02138 \\ June 2002
}

We thank Joshua Angrist, John Bound, David Card, Olivier Deschênes, Alan Krueger, Lawrence Katz, Peter Kuhn, Casey Mulligan, Bas ter Weel, Linda Wong, and seminar participants at UC Berkeley, Università Bocconi, the European University Institute, the University of Michigan, MIT, UC Santa Barbara, UC Santa Cruz, Stanford University, UCLA, University of British Columbia and Wharton for valuable suggestions, and the National Science Foundation and the Russell Sage Foundation for financial support. The views expressed herein are those of the authors and not necessarily those of the National Bureau of Economic Research.

(C) 2002 by Daron Acemoglu, David H. Autor and David Lyle. All rights reserved. Short sections of text, not to exceed two paragraphs, may be quoted without explicit permission provided that full credit, including (C) notice, is given to the source. 
Women, War and Wages: The Effect of Female Labor Supply

on the Wage Structure at Mid-Century

Daron Acemoglu, David H. Autor and David Lyle

NBER Working Paper No. 9013

June 2002

JEL No. J21, J22, J31, J16, N32, H56

\begin{abstract}
This paper investigates the effects of female labor supply on the wage structure. To identify variation in female labor supply, we exploit the military mobilization for World War II, which drew many women into the workforce as males exited civilian employment. The extent of mobilization was not uniform across states, however, with the fraction of eligible males serving ranging from 41 to 54 percent. We find that in states with greater mobilization of men, women worked substantially more after the War and in 1950, though not in 1940. We interpret these differentials as labor supply shifts induced by the War. We find that increases in female labor supply lower female wages, lower male wages, and increase the college premium and male wage inequality generally. Our findings indicate that at mid-century, women were closer substitutes to high school graduate and relatively low-skill males, but not to those with the lowest skills.
\end{abstract}

$\begin{array}{lll}\text { Daron Acemoglu } & \text { David H. Autor } & \text { David Lyle } \\ \text { Department of Economics } & \text { Department of Economics } & \text { Department of Economics } \\ \text { MIT, E52-380B } & \text { MIT, E52-371 } & \text { MIT } \\ \text { 50 Memorial Drive } & \text { 50 Memorial Drive } & \text { 50 Memorial Drive } \\ \text { Cambridge, MA 02142-1347 } & \text { Cambridge, MA 02142-1347 } & \text { Cambridge, MA 02142-1347 } \\ \text { and NBER } & \text { and NBER } & \text { dlyle@mit.edu } \\ \text { daron@mit.edu } & \text { dautor@mit.edu } & \end{array}$


"In May, 1947, 31.5 per cent of all women 14 years of age and over were workers as compared to 27.6 per cent in 1940. This proportion has been increasing for many decades. However, both the number and the proportion of women working in 1947 are believed to be greater than would have been expected in this year had there not been a war." Constance Williams, Chief of the Research Division of the Women's Bureau of the United States Department of Labor, 1949.

\section{Introduction}

In 1900, 82 percent of U.S. workers were male, and only 18 percent of women over the age of 15 participated in the labor force. As is visible in Figure 1, this picture changed radically over the course of the past century. In 2001, 47 percent of U.S. workers were women, and 61 percent of women over the age of 15 were in the labor force. Despite these epochal changes in women's labor force participation, economists currently know relatively little about how female labor force participation affects the labor market.

- Does it increase or decrease male wages?

- Does it adversely affect female wages?

- Does it impact male wage inequality?

The relative scarcity of convincing studies on this topic reflects the complexity of the phenomenon: increased labor participation of women is driven both by supply and demand factors. Women participate in the labor force more today than 100 years ago for a myriad of supplyside reasons including changes in tastes, gender roles and technology of household production. But women also participate more because there is greater demand for their labor services. To advance our understanding of how rising female labor force participation impacts the labor market, we require a source of "exogenous" variation in female labor supply.

In this paper, we study female labor force participation before and after World War II (WWII) as a source of plausibly exogenous variation in female labor supply. As evocatively captured by the image of Rosie the Riveter, the War drew many women into the labor force as 16 million men mobilized to serve in the armed forces, with over 73 percent leaving for overseas. As is depicted in Figure 2, only 28 percent of U.S. women over the age of 15 participated in 
the labor force in 1940. By 1945 this figure exceeded 34 percent. ${ }^{1}$ Although, as documented by Goldin (1991), more than half of the women drawn into the labor force by the War left again by the end of the decade, a substantial number also remained (see also Clark and Summers, 1982). In fact, the decade of the 1940s saw the largest proportional rise in female labor force participation during the 20th century.

Although this aggregate increase in female labor force participation is evident from Figures 1 and 2, it is not particularly useful for our purposes; the end of the War and other aggregate factors make the early 1950s difficult to compare to other decades. But, central to our research strategy, the extent of mobilization for the War was not uniform across U.S. states. While in some states, for example Massachusetts, Oregon, and Utah, almost 55 percent of males between the ages of 18 and 44 left the labor market to serve in the War, in other states, such as Georgia, the Dakotas and the Carolinas, this number was between 40 and 45 percent. These differences in mobilization rates reflect a variety of factors, including exemptions for farmers, differences in age, ethnic and occupational structures, as well as idiosyncratic differences in the behavior of local draft boards. We exploit differences in state WWII mobilization rates, as well as components of these mobilization rate differences that are plausibly exogenous to other labor market outcomes, to study women's labor supply.

Panels A and B of Figure 3 show that women worked substantially more in 1950 - but not in 1940 - in states with greater mobilization of men during the War (see below for the exact definition of the mobilization variable). Our baseline estimates suggest that women worked on average about 1 week more in a state that had a 10 percentage point higher mobilization rate during WWII, corresponding to a 9 percentage point increase in female labor supply. This difference is not accounted for by differences in age structure, racial structure, education or the importance of farming across these states, nor is it explained by differences in occupational structure, regional trends in labor supply, or contrasts between Southern and non-Southern states. We interpret these cross-state changes in female employment as caused by the greater participation of women during the War years, some of whom stayed in the labor market after the War ended. Notably, we find in Panel C of Figure 3 that the sizable association between WWII mobilization rates and growth in female labor supply over the 1940s did not recur in the 1950s, lending support to the hypothesis that these shifts were caused by the War, and not

\footnotetext{
${ }^{1}$ For convenience, we refer to Census years as 1940, 1950, etc. In reality, Census data provides labor supply information for the prior calendar year.
} 
by differential long-run trends in female employment.

Panel A of Figure 4 shows an equally strong relationship between female wage growth over the 1940s and WWII mobilization rates: in states with greater mobilization for war, female wages grew much less. Panel B shows a negative relationship for male wages as well, but the slope of the relationship is considerably less steep.

We interpret the relationships shown in Figure 4 as the causal effect of the WWII-induced increase in female labor supply on female and male wages. As Figure 2 shows, the aggregate demand shock that drew many women into the labor force during the mobilization years had reversed itself by 1947. But women continued to work in greater numbers after 1947, presumably because employment during the War changed their preferences, opportunities and information about available work.

Our interpretation of the relationship between mobilization, female labor supply, and wage growth faces two major challenges:

1. High- and low-mobilization states may be different in other unobserved dimensions. In that case, Figure 3 and 4 may be capturing the effect of these unobserved characteristics on labor market outcomes, and our identification strategy may be assigning the effects of these unobserved state characteristics on labor market outcomes to female labor supply.

2. Mobilization of men for war may have had a direct effect on the labor market, distinct from its impact through female labor supply. For example, men who served in the War may have had difficulty reintegrating into the workforce, or may have entered school instead due to the opportunities offered by the GI Bills (Bound and Turner, 1999; Stanley, 1999). If this were the case, our first-stage finding of a relationship between mobilization and female labor supply would remain valid, but our two-stage least square (2SLS) estimates would be biased: greater female labor force participation in high-mobilization states could reflect greater demand for female labor input rather than shifts in female labor supply.

Although we cannot dismiss these two interpretations entirely, we provide evidence to suggest that they are not the primary source of our findings. Our results are typically robust to including a variety of aggregate characteristics of states, including fraction of farmers before the War, racial, education, and occupational structures. We also obtain similar results when we focus on the component of mobilization rate generated by cross-state differences in aggregate 
age and ethnic structure, which were important determinants of state mobilization rates, but should plausibly have no direct effect on female labor supply growth once we condition on individual age and ethnicity. These findings weigh against an interpretation along the lines of the first objection above. Moreover, female labor force participation did not vary systematically between high- and low-mobilization states prior to the War, suggesting that these states were initially broadly comparable along this dimension. Finally, as Panel C of Figure 3 documents, high-mobilization states did not experience faster growth in female employment between 1950 and 1960. Hence, there do not appear to be differential state employment trends correlated with WWII mobilization rates.

If, on the other hand, the second concern were important - that is, if returning veterans had trouble reintegrating into the labor market - there should be lower labor force participation among men in 1950 in high-mobilization states. We find that this is generally not the case. Men who were not mobilized appear to participate slightly more after the War in highmobilization states. And post-war labor supply of WWII veterans in 1950 is, for the most part, comparable across high and low-mobilization states, though some specifications do show negative but insignificant effects. Furthermore, if greater female participation in 1950 were driven by demand rather than supply factors, we would expect relatively greater wage growth for both women and men in high-mobilization states. Instead, consistent with our interpretation, Figure 4 shows that both men and women earned relatively less in high-mobilization states in 1950 than in 1940. Nor are our results driven by cross-state wage convergence between agricultural and industrialized states during the 1940s (e.g., Wright, 1986); in specifications that control for lagged state wage measures, we continue to find a significant impact of mobilization on the structure of male and female earnings. Finally, Figure 5 shows no relationship between state WWII mobilization rates and wage growth between 1950 and 1960. Hence, the cross-state correlations that we exploit between WWII mobilization and female labor supply or relative wage changes by gender appear unique to the WWII decade.

Exploiting the differential growth in female employment between 1940 and 1950 related to cross-state differences in WWII mobilization, we estimate the impact of female employment on a range of labor market outcomes. Our main findings are:

1. Greater female labor supply reduces female wages. A ten percent increase in relative female labor supply (that is, relative to males) lowers female wages by 6 to 7 percent, 
implying a labor demand elasticity of -1.4 to -1.7 .

2. Greater female labor supply also reduces male wages. A 10 percent increase in the $(\log )$ ratio of female to male labor supply typically lowers male earnings by 3 to 5 percent.

3. The finding that female labor supply lowers women's wages by more than men's indicates that male and female labor inputs are imperfect substitutes. We estimate that a 10 percent increase in relative supply reduces relative female/male earnings by about 3 percentage points. This implies a substitution elasticity of approximately 3, which is large but far from perfect substitutability.

4. The impact of female labor supply on male earnings is not uniform throughout the male earnings distribution. A 10 percent increase in female relative labor supply raises earnings inequality between college and high school graduate males by about 1.5 percentage points and lowers earnings inequality between high school graduate and eight-grade males by about 2 percentage points. These findings indicate that the women drawn into the labor market by the War were closer substitutes to males at the middle of the skill distribution than those with either the lowest or highest education.

5. Although female labor supply has countervailing effects on educational differentials, its net impact on overall and residual earnings inequality among males is positive. A 10 percent increase in female labor supply is estimated to increase the male 90-10 weekly earnings differential by 5.5 log points, which is a very sizable effect.

It is important to note that these estimates conceptually correspond to short-run elasticities since we are looking at equilibria in state labor markets shortly after the War, that is, shortly after the changes in female labor supply. Migration, changes in interstate trade patterns and changes in technologies could make the long-run relationship between labor market outcomes and female labor supply quite different from the short-run relationship. Results exploiting changes between 1940 and 1960 suggest that long-run elasticities are indeed larger than shortrun elasticities.

The economics literatures on the effect of WWII on female participation and the effect of female labor supply on the structure of wages contains a small number of well-known contributions. Goldin (1991) is most closely related to our work. She investigates the effects of WWII 
on women's labor force participation and finds that a little over half of the women who entered the labor market during the War years exited by 1950. Our labor supply estimates appear consistent with these findings, though differences in the sample frame make it difficult to make exact comparisons. Mulligan (1998) investigates the causes of the increase in labor supply during the War, and concludes that non-pecuniary factors rather than market incentives drove this growth. Neither Goldin nor Mulligan nor, to the best of our knowledge, any other author investigates the relationship between cross-state mobilization rates and female labor supply, nor the causal effect of the induced change in female labor supply on labor market outcomes of men..$^{2}$

Blau and Kahn (1999), Juhn and Kim (1999), Topel (1994 and 1997) and the short papers by Fortin and Lemieux (2000) and Welch (2000) also investigate the effect of female employment growth on male wage inequality. ${ }^{3}$ Using Current Population Survey data from 1968-1990, Topel (1994) finds a strong positive correlation between regional changes in female labor supply and growth in male earnings inequality. By contrast, Juhn and Kim (1999) do not find a sizable effect of female labor supply on male wage inequality in a cross-state Census panel. Fortin and Lemieux hypothesize that the increase in male wage inequality during the past several decades may reflect the process of women substituting for males in the earnings distribution, and provide time-series evidence on the correlations between percentiles of the male and female wage distribution that are consistent with this hypothesis. Finally, Welch (2000) links both the decline in the wages of low-skill men and the narrowing of the male-female wage gap over the past three decades to the overall increase in the demand for skills. While each of these analyses reaches provocative, albeit divergent, conclusions, the identification strategies used do not provide a means to separate supply- and demand-induced changes in female employment. What distinguishes our analysis is the use of plausibly exogenous variation in female labor market participation induced by World War II mobilization.

In the next section, we briefly discuss the predictions of a simple competitive model regarding the effect of increased female labor force participation on male labor market outcomes. Section

\footnotetext{
${ }^{2}$ An unpublished dissertation by Dresser (1994) studies the relationship between federal war contracts and labor market participation of women across metropolitan areas and finds that MSAs that had a relatively large number of war contracts during the war experienced differential increases in female labor force participation between 1940 and 1950.

${ }^{3}$ Goldin and Margo (1992) provide the seminal work on changes in the overall structure of earnings during the decade of the War. For excellent syntheses of the state of knowledge of the role of women in the labor force, see Goldin (1990 and 1994), Blau, Ferber and Winkler (2002), Blau and Kahn (1994, 1997 and 2000), and O'Neill and Polachek (1993).
} 
3 describes our microdata and documents the correlation between female employment and a range of female and male labor market outcomes. In Section 4, we provide a brief overview of the draft and enlistment process for World War II, and explain the causes of the substantial differences in mobilization rates across states. Section 5 documents the relationship between WWII mobilization rates and female labor supply in 1950, and argues that mobilization rates generate a plausible source of exogenous variation in female labor supply. Sections 6 and 7 contain our main results. They exploit cross-state differences in female labor supply induced by mobilization rates to estimate the impact of increased female labor supply on female wages and male wages, educational inequality, and overall earnings inequality among males. Section 8 concludes.

\section{Some Simple Theoretical Ideas}

To frame the key questions of this investigation, it is useful to briefly discuss the theoretical implications of increased female labor force participation. Consider a competitive labor market consisting of four factors: high-skill males, $H_{t}$, low-skill males, $L_{t}$, females, $F_{t}$, and capital, $K_{t}$, which stands for all nonlabor inputs. ${ }^{4}$ Imagine that all these factors are imperfectly substitutable in the production of a single final good. In particular, to fix ideas, consider the following nested CES (constant elasticity of substitution) aggregate production function, where, to simplify notation, we ignore the share parameters:

$$
Y_{t}=A_{t} K_{t}^{1-\alpha}\left[\left(B_{t}^{L} L_{t}\right)^{\eta}+\left(\left(B_{t}^{F} F_{t}\right)^{\rho}+\left(B_{t}^{H} H_{t}\right)^{\rho}\right)^{\eta / \rho}\right]^{\alpha / \eta}
$$

where $A_{t}$ is a neutral productivity term, and the $B_{t}$ 's are factor-augmenting productivity terms, which are for now taken as exogenous. In particular, $B_{t}^{F}$ is an index of female productivity, which may reflect observed or unobserved components of female human capital as well as technical change favoring women relative to men. This specification assumes that the elasticity of substitution between the labor aggregate and nonlabor inputs is equal to 1, the elasticity of substitution between female labor and high-skill male labor is $1 /(1-\rho)$, and the elasticity of substitution between low-skill male labor and the aggregate between female and high-skill male labor is $1 /(1-\eta)$. When $\eta>\rho$, female labor competes more with low-skill male labor

\footnotetext{
${ }^{4}$ We do not distinguish between high- and low-skill females both to reduce the number of factors and because, in the empirical work, we will only have a source of exogneous variation in the total number (or total efficiency units) of females in the labor force.
} 
than high-skill male labor, whereas when $\eta<\rho$, it competes more with high-skill male labor. This nested CES is similar to the one used by Krusell et al. (2000) with high-skill and low-skill labor, and equipment capital.

In this model, the wage ratio of high-skill to low-skill male wages, corresponding to the skill or education premium, is a natural index of male wage inequality. Since in competitive labor markets, wages are equal to marginal products, this ratio will be

$$
\omega_{t} \equiv \frac{w_{t}^{h}}{w_{l t}^{l}}=\frac{B_{t}^{H}}{B_{t}^{L}} \frac{\left(B_{t}^{H} H_{t}\right)^{\rho-1}\left(\left(B_{t}^{F} F_{t}\right)^{\rho}+\left(B_{t}^{H} H_{t}\right)^{\rho}\right)^{(\eta-\rho) / \rho}}{\left(B_{t}^{L} L_{t}\right)^{\eta-1}}
$$

It is then straightforward to show that

$$
\operatorname{Sign}\left\langle\frac{\partial \omega_{t}}{\partial B_{t}^{F} F_{t}}\right\rangle=\operatorname{Sign}\langle\eta-\rho\rangle,
$$

that is, an increase in effective female labor supply increases male wage inequality when women compete more with low-skill males than with high-skill males, i.e., when $\eta>\rho$. If female labor has traditionally been a closer substitute to low-skill male labor than high-skill male labor as argued by Grant and Hamermesh (1981) and Topel (1994 and 1997) among others, we may expect increased female labor force participation to act as a force towards greater wage inequality among men. The empirical magnitude of this effect is unclear, however.

The effect of increased female labor force participation on average wages of men, or on the level of high-skill and low-skill wages, depends upon the elasticity of supply of nonlabor inputs. It is straightforward to verify that if these nonlabor inputs are supplied elastically (or if $\alpha=1$ ), increased female labor supply will always raise average male wages. If, on the other hand, the supply of nonlabor inputs to the economy is upward sloping, the effect is ambiguous, and depends on the elasticity of substitution between male and female labor and on the response of the rental price of these nonlabor inputs to the increase in female labor supply.

More explicitly, low-skill male wages are

$$
w_{t}^{l}=\alpha A_{t} K_{t}^{1-\alpha}\left[\left(B_{t}^{L} L_{t}\right)^{\eta}+\left(\left(B_{t}^{F} F_{t}\right)^{\rho}+\left(B_{t}^{H} H_{t}\right)^{\rho}\right)^{\eta / \rho}\right]^{(\alpha-\eta) / \eta}\left(B_{t}^{L} L_{t}\right)^{\eta-1} .
$$

Holding the supply of nonlabor inputs fixed, we have that

$$
\operatorname{Sign}\left\langle\frac{\partial w_{t}^{l}}{\partial B_{t}^{F} F_{t}}\right\rangle=\operatorname{Sign}\langle\alpha-\eta\rangle \text {. }
$$


In other words, when the elasticity of substitution parameter, $\eta$, is sufficiently high relative to the share of labor in production, $\alpha$, an increase in female labor supply will reduce the (conditional) demand for and the earnings of low-skill males. In what follows, we will loosely refer to female and (a particular type of) male labor as "close substitutes" when greater female employment reduces the wages of that type of male labor, since a greater level of $\eta$ (i.e., a greater elasticity of substitution) makes such negative wage effects more likely.

The same trade-offs determine whether average male wages increase or decline in response to increased female labor force participation. Substitution of female labor for male labor, by reducing the ratio of nonlabor inputs to effective labor, acts to depress earnings, while the complementarity between female and male labor raises the earnings of men. The overall effect will be determined by which of these two forces is stronger.

Can we use this framework to interpret the relationship between female labor supply and wages at the state level in the aftermath of WWII? There are at least three caveats that apply:

1. This interpretation requires U.S. states to approximate separate labor markets. This may be problematic if either migration makes the entire U.S. a single labor market, or if local labor markets are at the city or MSA level. Both problems would cause attenuation, which does not bias instrumental-variables estimates, but makes them less precise. For example, in the extreme case where migration is free and rapid, there would be no systematic relative employment and factor price differences across state labor markets. Many studies, however, find migration to be less than perfect in the short run (e.g., Blanchard and Katz, 1992, Bound and Holzer, 2000, Card and DiNardo, 2000), while others document significant wage differences across state or city labor markets (e.g., Topel, 1994, Acemoglu and Angrist, 2000, Moretti, 2000, Bernard, Jensen and Schott, 2001, Hanson and Slaughter, 2002, forthcoming).Our results also show substantial differences in relative employment and wages across states related to WWII mobilization.

2. The single-good setup is an important simplification. When there are multiple goods with different factor proportions, trade between different labor markets can also serve to equalize factor prices (Samuelson, 1948). It is reasonable to presume that changes in interstate trade patterns required to achieve factor price equalization do not take place 
in the short run. ${ }^{5}$

3. Short-run and long-run elasticities may also vary significantly, either because there are factors, such as capital or entrepreneurial skills, that adjust only slowly (cf, the LeChaterlier principle in Samuelson, 1947), or because technology (organization of production) is endogenous and responds to the availability of factors (Acemoglu, 1998, 2002).

In light of all these caveats, the elasticities we estimate in this paper should be interpreted as short-run elasticities (except when we look at the two-decade change between 1940 and 1960). The majority of the estimates exploit the differential increase in female labor supply at the end of the War on labor market outcomes shortly after the War. Migration, changes in interstate trade patterns and changes in technologies are likely to make the long-run relationship between female labor supply and labor market outcomes quite different from the short-run relationship.

\section{Data Sources and OLS Estimates}

\subsection{DATA}

Our basic data come from the one-percent Integrated Public Use Microsamples (IPUMS) of the decennial Censuses. Samples include males and females ages 14-64 in the year for which earnings are reported who are not residing in institutional groups quarters (such as prisons or barracks), are not employed in farming, and who reside in the continental United States. Throughout the paper, we exclude Alaska, Hawaii, Washington D.C. and Nevada from the analysis. Alaska and Hawaii were not states until the 1950s, while Nevada underwent substantial population changes during the critical period of our analysis. ${ }^{6}$ The 1950 sample is further limited to the sample-line subsample because educational attainment is not reported in the full sample. Sampling weights are employed in all calculations. Earnings samples include all full-time, full-year workers in paid non-farm employment excluding self-employed who earned the equivalent of $\$ 0.50$ to $\$ 250$ an hour in 1990 dollars during the previous year (deflated by CPI All Urban Consumers series CUUR0000SA0). Weekly earnings are computed as total wage and salary income earned in the previous year divided by weeks worked in the previous year, and hourly earnings are computed as wage/salary income divided by weeks worked in the previous year and hours worked in the

\footnotetext{
${ }^{5}$ This is especially true at midcentury, since construction of the U.S. Interstate Highway System did not begin until 1956 with the authorization of the Federal Aid-Highway Act.

${ }^{6}$ Nevada had an extremely high mobilization rate, yet despite this, lies directly along the regression line for most of our analyses. Inclusion of Nevada affects none of our results
} 
previous week. ${ }^{7}$ Top coded earnings values are imputed as 1.5 times the censored value. We define full-time, full-year employment as working at least 35 hours in the survey week and 40 weeks in the previous year. Because weeks worked in 1940 are reported as full-time equivalent weeks, we do not impose the hours restriction for the full-time 1940 sample and when making hourly wage calculations, we count full-time equivalent weeks as 35 hours of labor input.

Table 1 provides descriptive statistics for the 1940, 1950 and 1960 Censuses, which are our main samples. Statistics are given for all the 47 states in our sample, and also separately for states with high, medium and low-mobilization rates, corresponding to below 45.4, between 45.4 and 49.0, and above 49.0 percent mobilization. This distinction will be useful below since differences in mobilization rates will be our instrument for female labor supply. Details on the construction of mobilization rates are given in Section 4.

As is visible in Table 1, high-mobilization states have higher average education, higher wage levels, and slightly older populations than low-mobilization states in 1940. Farm employment and nonwhite population shares are considerably lower in these states. However, female labor supply, measured by average weeks worked per woman, does not differ among high-, mediumand low-mobilization states in 1940.

\subsection{Female Employment and the Level and Distribution of Earnings}

In this section, we document the cross-state correlations between female labor supply and their range of labor market outcomes over the five decades between 1940-1990. Table 2 presents the relationship between female employment and a variety of aggregate state labor market outcomes including female and male wages, male earnings inequality, and the male college/high school earnings differential. In all these models, our measure of female labor supply is average weeks worked by female state residents aged 14 to 64 (with other sample restrictions as above).

In Panels $\mathrm{A}$ and B, we measure wages as log weekly earnings of full-time, full-year workers, and control for year main effects, state of residence and state or country of birth dummies, a full set of education dummies, a quartic in (potential) experience, and dummies for nonwhite and marital status. As in all wage models we report in this paper, all covariates other than the state dummies are interacted with time to allow returns to education, experience and demographics

\footnotetext{
${ }^{7}$ The 1940 Census does not distinguish between wage/salary and self-employment income and hence both sources are implicitly used in earnings calculations. Restricting the sample to non-farm employed likely substantially reduces the importance of self-employment income in the 1940 sample.
} 
to differ by decade. ${ }^{8}$ The results show no consistent relationship between female employment on the one hand and female earnings and male earnings on the other. For example, column 1, which uses data from 1940 and 1990, indicates that greater female employment is associated with an increase in female wages, and a slight decline in male wages. Other columns report results for different subsamples.

Panel C reports the relationship between female labor supply and the male college/high school wage premium. To perform this calculation, we regressed log weekly full-time earnings of males with exactly a college and those exactly a high school degree on year main effects, state of birth and state of residence dummies, and the same set of covariates and their interactions with time, and the measure of average weeks worked by females in their state of residence. Each variable (and the constant) is interacted with a college-graduate dummy and the coefficient reported is the interaction between the female labor supply measure and the college graduate dummy. This coefficient measures the relationship between female labor supply and the earnings of college graduates relative to high school graduates (see equation (7) below). Panel C shows a weak negative relationship between female labor supply and the male college/high school wage differential: in the full sample and in 1970-90, a 1 week increase in female employment is associated with a 1 percent decline in the college/high school differential.

Finally, Panel D reports results from regressions of within-state changes in overall male earnings inequality on changes in female weeks worked. The measure of inequality used here is the log difference between the 90th and 10th percentiles of the male earnings distribution. The results show no relationship between overall male wage inequality and female labor supply between 1940 and 1990 or between 1970 and 1990, but during earlier decades, there is a positive association between female employment and male wage inequality, and this relationship is significant in the 1940s.

If the results in Table 2 corresponded to the causal effect of female employment on female and male wages, we would conclude the demand for female labor was highly elastic (effectively flat), and that male and female workers were not particularly close substitutes.

These conclusions would be premature, however, since variations in female employment reflect both supply and demand forces. ${ }^{9}$ To the extent that female labor supply responds

\footnotetext{
${ }^{8}$ Results without such interactions are similar, and are available upon request.

${ }^{9}$ An additional problem is composition bias: women who participated at the margin may have been different (say less productive) than the average woman, creating a spurious negative relationship between female em-
} 
elastically to labor demand, the OLS estimate of the effect of female employment on female wages will be biased upward by simultaneity; that is, female labor supply will be positively correlated with the level of labor demand and hence positively correlated with wages. Similarly, to the extent that demand for male and female labor move together, the OLS estimate of the effect of female employment on male wages will also be biased upward. On the other hand, the OLS estimates of the effect of female labor supply on male wage inequality may be biased upward or downward depending on whether greater labor demand increases wages more at the top or the bottom of the residual earnings distribution.

To obtain unbiased estimates of the effect of female employment on these labor market outcomes, we require a source of variation in female labor supply that is uncorrelated with demand for female labor. In the next section, we explore whether variation in state mobilization rates for WWII may serve as such a source of variation.

\section{Mobilization For World War II}

Following the outbreak of the War, the Selective Service Act, also known as the BurkeWadsworth Bill, was introduced in the Senate in June 1940 to correct flawed conscription policies from the World War I era. The Burke-Wadsworth Bill initiated a mandatory national registration in October 1940 for a draft lottery for all males ages of 21-35 to gather relevant data on potential draftees. By the time the draft ended in 1947, there had been a total of six separate registrations with the age range expanded to include 18-64 year olds. Only 18-44 year olds were liable for military service, however, and many of these either enlisted or were drafted for the War. Men aged 45-64 were registered as part of a civilian workforce management effort by the Selective Service.

Following each of the registrations, there were a series of lotteries determining the order that a registrant would be called to active duty. Local draft boards then classified all of the registrants into qualification categories. The Selective Service's guidance for deferred exemption was based on marital status, fatherhood, essential skills for civilian war production, and temporary medical disabilities, but left considerable discretion to the local boards.

ployment and female wages. Our instrumental-variables estimates will also be subject to a variant of this bias: IV estimates will identify the market effects of the labor supply of women whose behavior is affected by our instrument; these women may differ from the "average" female labor force participant (see Angrist and Imbens, 1995, for an interpretation of IV estimates along these lines). 
Due to the need to maintain an adequate food supply to support the War effort, one of the main considerations for deferment was farm status. We show below that states with a higher percentage of farmers had substantially lower mobilization rates, and this explains a considerable share of the variation in state mobilization rates. Also, most military units were still segregated in the 1940s and there were relatively few black units. Consequently, blacks were separated from whites for classification purposes. This resulted in proportionally fewer blacks serving in the military than whites and hence states with higher percentages of blacks also had lower shares of draftees. In addition, individuals of German, Italian and Asian origin may have been less likely to be drafted due to concerns about sending them to battle against their countries of origin.

Our measure of the mobilization rate is the fraction of registered males between the ages of 18 and 44 who were drafted or enlisted for war. It is calculated from the published tables of the Selective Service System (1956). Since effectively all men in the relevant age range were registered, our mobilization rate variable is the fraction of men in this age range who have served. We use this variable as a proxy for the decline in the domestic supply of male labor induced by the War. Volunteers were not accepted into the military after 1942 and hence the great majority of those who served, 67 percent, were drafted. ${ }^{10}$ Therefore, the main source of variation in mobilization rates is cross-state differences in draft rates.

Table 3 shows the cross-state relationship between the mobilization rate and a variety of potential determinants. These right-hand side variables, calculated from the 1940 Census, measure the percent of males ages 13-44 in each state who were farmers, nonwhite, married, fathers, German-born or born in other Axis nations (Italy or Japan), or fell in the age brackets of 13-24 and 24-34. We also calculate average years of completed schooling among males in this age bracket since, as Table 1 shows, this variable differs significantly among high- and low-mobilization states. We focus on the age bracket 13-44 because men aged 13 in 1940 would be 18 in 1945, and thus part of the target ("at-risk") group. ${ }^{11}$ Finally, we calculate the number of draft registration boards per 1,000 males ages 13-44 using Selective Service (1956) paired to

\footnotetext{
${ }^{10}$ According to data from Selective Service System (1956), 4,987,144 men were enlisted and 10,022,367 men were drafted during the War years. 458,297 males were already serving in the military in 1940 prior to declaration of hostilities. Since it is probably misleading to count these peacetime enlistees as wartime volunteers, a more precise estimate of the share of draftees is 70 percent.

${ }^{11}$ The fathers variable refers to the fraction of women aged 13-44 who had children. Though ideally we would have this fraction for men, this information is not directly available from Census and hence we use the percent of women with children, which is presumably highly correlated with the desired variable.
} 
Census population counts. Draft board prevalence might affect the mobilization rate if states with greater mobilization infrastructure were able to conduct the draft more rapidly.

Column 1 of Table 3, which includes all of these variables in a regression model simultaneously, shows that the farm, schooling and German-born variables are significant, while the other variables are not. The significant negative coefficient on the farm variable implies that a state with 10 percentage points higher farm penetration is predicted to have a 1.7 percentage point lower mobilization rate. The coefficient on the German-born variable implies that 1 percentage point higher fraction of population born in Germany translates into over 3 percentage points lower mobilization. This is a very large effect, though not entirely implausible if our measure of foreign-born Germans also captures the presence of larger ethnic German enclaves (also note that the point estimate is significantly smaller in later columns). Interestingly, the percent Italian/Japanese variable has the wrong sign in this regression, but this seems to be because it is correlated with percent German-born, and when entered individually, it is insignificant. Column 2 displays a specification that includes only the farm and nonwhite variables, while column 3 shows a specification only with the farm and education variables. Column 4 combines the farm, nonwhite and schooling variables. Due to collinearity, neither the nonwhite nor schooling variable is individually significant.

To explore robustness, column 5 drops the 15 Southern states from the analysis. Their omission has little impact on the farm or schooling variables, though it does cause the coefficient and standard error of the nonwhite population share measure to rise substantially. The subsequent columns add the age structure, ethnic mix, married, father and local draft board variables one by one to the model in column 4 . The only variables that have additional explanatory power are the age structure and percent German-born variables.

Finally, columns 12 and 13 show specifications that control for the farm, nonwhite, schooling, age composition and the German-born variables simultaneously. These specifications explain a significant part of the variation in state mobilization rates (the $\mathrm{R}^{2}$ 's of these two regressions are, respectively, 0.62 and 0.70). We think of the farm, nonwhite and schooling variables as capturing potentially "economic" determinants of mobilization rates, and the age composition and the German-born variables as capturing systematic "non-economic" components, while the residual 30 percent corresponds to idiosyncratic or non-systematic variation. Below we present estimates of the effect of mobilization on female labor supply growth that exploit 
various combinations of these sources of variation.

\section{WWiI Mobilization and Female Labor Supply}

\subsection{Cross-State Relationships}

Figure 2 in the Introduction showed male and female labor force participation and the fraction of males ages 14-65 who were in active military duty in each year during the years 19401952. ${ }^{12}$ The rise of women's labor force participation between 1940 and 1945 closely tracks the mobilization of males. During these five years, male labor force participation declined by 16.5 percentage points while female labor force participation rose by 6.0 percentage points. Hence, the rapid increase in female employment during 1940-1945 appears to be a response to the labor demand shock caused by WWII mobilization.

By 1949, the size of the military was at peacetime levels, male labor force participation slightly exceeded pre-War levels, and the demand shock that had induced the increase in female employment had arguably subsided. Despite the resumption of peacetime conditions, however, female labor force participation was 5.1 percentage points higher in 1950 than in 1940 (though 0.9 percentage points lower than at the War's peak). ${ }^{13}$ If female employment was higher in 1950 than it would have been absent WWII mobilization, this can be thought as the result of a change in female labor supply behavior induced by the War. Women who worked during wartime may have potentially increased their earnings capacity or their information about available jobs, thereby inducing additional labor supply. ${ }^{14}$ Alternatively, the preferences of women who worked-or even those who did not-may have been altered by widespread female labor force participation during the War. Our empirical strategy is to exploit these changes in female labor supply.

\footnotetext{
${ }^{12}$ Numerators for labor force participation and military active duty numbers in Figure 2 are from the Statistical Abstract of the United States (1944/45, 1951, and 1954), which relies on estimates from Census of Populations data for years 1940-1942 and Current Population Reports, Series P-50 and P-57, for years 19431952. Denominators are population estimates of U.S. residents ages 14-65 by gender from 1940 and 1950 Census of Populations. Population estimates are interpolated for years 1940-1948 and 1950-52 assuming a constant exponential growth rate over 1939-1952. Due to use of the detailed annual labor force series for 1939-1952 in Figure 2 (which are not available for earlier years), our female labor force participation numbers in this figure differ slightly from the series provided by Goldin (1994) and Blau, Ferber and Winkler (2002) displayed in Figure 1.

${ }^{13}$ As noted earlier, our data sources do not agree on the exact magnitude of the aggregate rise in female labor force participation during the decade. The Figure 1 data place the rise at 6.0 percentage points rather than 5.1 as in Figure 2.

${ }^{14}$ In this case, the actual increase in efficiency units supplied by female labor may be understated by our labor supply calculations (which are normally expressed in weeks worked), leading to an underestimate of the negative effect of female labor supply on female wages.
} 
Mobilization for WWII was not uniform across states. In low-mobilization states, less than 44 percent of men between the ages of 18-44 served in the War, in contrast to 51.5 percent of males in high-mobilization states (with a range of 9.2 percentage points between the 10th and 90th percentile states). Figure 3 showed that female employment did not systematically vary between high- and low-mobilization states in 1940 (see also Table 1). By 1950, however, women worked significantly more in high-mobilization states. In fact, as shown in the second panel of the figure, there is a striking positive relationship between state mobilization rates and the change in average weeks worked by women from 1940 to 1950. Our hypothesis is that this change in the cross-state pattern of female employment between 1940 and 1950 reflects the effects of WWII mobilization on female labor supply. Notably, this positive relationship is unique to the decade of the War. The bottom panel of Figure 3 indicates that there is no additional relative growth in female labor supply during 1950-1960 in high-mobilization states (in fact, there is a slight mean reversion).

To investigate the hypothesis more formally, Table 4 reports results from regressions of female labor supply, measured in weeks worked, on state mobilization rates. These models, which pool data from 1940 and 1950, have the following structure:

$$
y_{i s t}=\delta_{s}+\gamma_{1950}+X_{i s t}^{\prime} \cdot \beta_{t}+\alpha \cdot \gamma_{1950} \cdot m_{s}+\varepsilon_{i s t}
$$

Here the left-hand side variable, $y_{i s t}$, is weeks worked by woman $i$ residing in state $s$, in year $t\left(1940\right.$ or 1950). $\delta_{s}$ denotes a full set of state of residence dummies, and $\gamma_{1950}$ is a dummy for 1950. $X_{i s t}$ denotes other covariates including state of birth or country of birth, age, race, and share of farmers and nonwhites and average schooling in the state in 1940 interacted with the 1950 dummy, which are included in some of the specifications. The time subscript on $\beta$ indicates that the effects of the $X^{\prime} s$ on labor supply may differ by decade. The coefficient of interest is $\alpha$, which corresponds to the interaction term between the 1950 dummy and the mobilization rate, $m_{s}$. To save on terminology, we refer to this interaction term simply as the "mobilization rate". This variable measures whether states with higher rates of mobilization for WWII experienced a greater increase in female employment from 1940 to 1950. Since our key right-hand side variable, the mobilization rate, varies only by state and year, all standard errors reported in this paper are corrected for clustering at the state times year level (using STATA robust standard errors). 
Column 1 is our most parsimonious specification, including only state dummies, year main effects, and the mobilization rate measure. This model indicates that there was a large and highly significant increase in female employment between 1940 and 1950 in high-mobilization states. The point estimate of 13.9 (standard error 1.8) implies that a 10 percentage point higher mobilization translated into a 1.4 week increase in female employment between the start and end of the decade. While suggestive, this specification is not entirely appropriate since it does not control for any individual or state characteristics that might explain the rise in female labor supply in high-mobilization states. Subsequent columns add a variety of covariates to this specification.

The addition of a full set of age and marital status dummies interacted with year dummies in column 2 reduces the mobilization rate coefficient by about one-third to 9.6. The difference in the point estimate between the first two columns indicates that age groups with greater increases in labor force participation were more populous in high-mobilization states. Column 3 adds state of birth dummies as a control for cross-state migration (and country of birth dummies for immigrants). These dummies have little impact. As an additional method of controlling for the possible endogeneity of women's location decisions, Appendix Table 1 displays a set of specifications comparable to Table 4 (columns 3 and 5) in which WWII mobilization rates are assigned to women by their state of birth rather than current state of residence as in our main models. The point estimates and standard errors are very similar to the models in Table 4. As a final check for migration, Panel B of Appendix Table 1 reports results from specifications that use $(\log )$ total supply of women, measured in aggregate weeks or aggregate efficiency units, as the dependent variable (see below for definition of aggregate efficiency units). Consistent with the finding that women worked more on average in 1950 in high-mobilization states, total female labor supply also grew more in these states.

\subsection{Correlation or Mobilization?}

The correlations documented above between state mobilization rates and measures of agricultural employment, nonwhite population, and educational attainment raise a concern as to whether we are simply capturing differential trends in female employment in non-agricultural, better-educated, and low-minority states. In that case, the estimated effect of the mobilization rate on female labor supply growth will reflect, at least in part, this correlation. To state 
the concern more concretely, we can think of the variation in cross-state mobilization rates as arising from three components:

$$
m_{s}=m_{s}^{e}+m_{s}^{n e}+e_{s}
$$

The first of these, $m_{s}^{e}$, is the component of state mobilization rates that is correlated with observable economic factors such as agricultural and educational distributions. The second component, $m_{s}^{n e}$, is correlated with non-economic factors that we can potentially measure such as age and ethnicity. Finally, $e_{s}$ is a source of other idiosyncratic variation that we cannot proxy with our existing data. Our estimates so far exploit all three sources of variation in $m_{s}$. Among these, $m_{s}^{e}$ is the most problematic since economic factors that cause differences in mobilization rate could also potentially impact female labor supply and earnings growth directly between 1940 and 1950.

Our first strategy to purge the mobilization measure of potentially problematic variation is to control directly for several measures of $m_{s}^{e}$ in estimating (2), thus only exploiting the variation in mobilization rates coming from $m_{s}^{n e}$ and $e_{s}$. To implement this approach, columns 4 and 5 of Table 4 add controls for the interaction between the 1950 dummy and the fractions of men who were farmers and who were nonwhite and average schooling among men in $1940 .{ }^{15}$ The nonwhite and farm interaction terms are typically only marginally significant while the schooling variable is positively related to growth in female labor force participation. But these variables have little impact on the coefficient on the mobilization rate, which remains between 8 and 10 week and is highly significant. Overall, these estimates also imply that a 10 percentage point higher mobilization rate is associated with an approximately 1 week increase in female employment.

As an alternative check on the influence of racial composition on male employment growth, Panel B of Table 4 limits the sample to white females (recall that we have already limited the sample to non-farmers). The results in this subsample are comparable to those reported in Panel A. The baseline estimate is again approximately 9 to 10 weeks, and is similarly robust in magnitude and significance to the inclusion of various covariates. ${ }^{16}$

Another concern is that there may be significant cross-state differences in the importance of

\footnotetext{
${ }^{15}$ Although the component of mobilization rate correlated with fraction nonwhite may be thought to be "noneconomic," given the changes in the economic status of blacks over this time period, we are more comfortable classifying this as an "economic" complement.

${ }^{16}$ We also estimated models with interactions between individual education dummies and year dummies. The results are very similar to those in Table 4 . Tables of these results are available from the authors.
} 
occupations or industries with a greater demand for women, explaining the differential growth in female employment between 1940 and 1950. Table 5 allows for female labor supply growth to differ by states' initial occupational and industrial structure. In particular, we control (in separate regressions) for the interaction between the 1950 dummy and the fraction of males in 1940 in each of 10 one-digit occupations as well as the fraction of men in defense-related industries. ${ }^{17}$ These estimates provide little evidence of differential female labor supply growth by occupational and industrial structure. The occupation and industry variables are insignificant in all but one specification, and their inclusion affects neither the magnitude nor the significance of the relationship between WWII mobilization and female labor supply growth.

In terms of the notation of equation (3), the estimates in Tables 4 and 5 exploit two sources of variation in state mobilization rates: the "non-economic" component, $m_{s}^{n e}$, and the "idiosyncratic" component, $e_{s}$. An alternative strategy to explore whether these results may be interpreted as a causal effect of WWII mobilization on female labor supply growth is to attempt to isolate the non-economic component of the mobilization rate, $m_{s}^{n e}$. To implement this approach, we focus on the variation in mobilization rates accounted for by differences in the age structure and German heritage of the population of males at risk for mobilization by state (recall that the fraction of those who were Italian and Japanese did not have a significant effect on mobilization rates in Table 3). Conditioning on individual characteristics, in particular, age and ethnicity (country of birth), it is plausible that these variables should have no direct effect on female labor supply growth.

Motivated by this reasoning, we report results from 2SLS estimation of equation (2) in Panel A of Table 6, using the 1940 age or ethnic structure (or both) as instruments for the mobilization rate (in these models we also control for percent farmer and male's average education in 1940). Though not as precisely estimated, the results of these 2SLS models are similar to the previous estimates using all components of the variation in mobilization rates and to those that control for the economic component of the mobilization rate, $m_{s}^{e}$, directly. Therefore, it appears that all sources of variation in mobilization rates exert a similar effect on female labor supply during the decade of the War. It is also encouraging to note that the 2SLS models for male labor supply in Panel B of Table 6 find insignificant and inconsistently signed effects of mobilization on male

\footnotetext{
${ }^{17}$ We define defense-related industries as those contributing to War Stock material directly related to combat missions. Examples of defense industries are: aircraft and ship building, motor vehicles and electronic machinery, metal industries, steel and iron industries, and blast furnaces and rolling mills. A complete list is available from the authors.
} 
labor supply during this decade (see Table 8 for a more detailed analysis of the relationship between male labor supply growth and WWII mobilization). ${ }^{18}$

We provide a number of further robustness checks on our main estimates in Table 7. Specifically, we present results for a second outcome measure (positive weeks worked), explore the importance of regional variation to the main findings, and compare the 1940-1950 results to estimates for the subsequent decade when there was no mobilization for war. We focus on specifications 3 and 5 from Table 4, which are our richest models; the latter includes all state 'economic' controls (i.e., farm, nonwhite, and average years of completed schooling, all interacted with the 1950 dummy).

The first row of the table indicates that our results are not primarily driven by regional trends in female labor supply. Adding region dummies (interacted with the 1950 dummy) corresponding to the 4 Census regions increases the estimated relationship between the mobilization rate and female employment growth, but does not change the overall pattern. Dropping Southern states, on the other hand, reduces the size of the coefficient. In all cases, the relationship remains economically and statistically significant.

The second row of Table 7 presents identical models where the dependent variable is an indicator variable equal to 1 if a woman worked positive weeks in the previous year (and zero otherwise). In all but the first specification, these models indicate a sizable impact of the mobilization rate on the share of women participating in the labor force. A ten percent higher mobilization rate is associated with 1 to 3 percentage points additional growth in female labor force participation over this decade. ${ }^{19}$

Panel B of Table 7 presents comparable estimates for the years 1950 to 1960, in this case interacting the mobilization fraction with a 1960 dummy. These results provide a useful specification test since a large increase in female employment in high-mobilization states between 1950 and 1960 would indicate that our mobilization rate variable is likely capturing other secular

\footnotetext{
${ }^{18}$ We have also performed a "falsification" exercise for this IV approach in which we regress the change in female (or male) labor supply during 1950-1960 on lagged state age and ethnic variables from the 1950 decade interacted with a 1960 dummy. F-tests of these "false instruments" are never significant in models that use the state ethnic structure as the instrument. In models that include the age structure age alone or the age and ethnic structures together, p-values range from 0.01 to 0.03 , though age variables have the opposite sign to those in Table 6.

${ }^{19}$ We do not investigate the effect of the mobilization rate on the Census variable that is coded as in-thelabor-force, since in the 1940 census this is equivalent to having an occupation, and women who worked during the War may still have an occupation even if they are not currently in the labor force. Closely related, however, we show in Appendix Table 1 that there is a strong positive relationship between WWII mobilization and the logarithm of total female labor supply to a state.
} 
cross-state trends in female employment. In no case do we find a significant positive relationship between the mobilization variable and the growth of female labor supply measured as average weeks worked or any weeks worked over the 1950-60 decade. The cross-state growth in women's labor force participation was significantly correlated with WWII mobilization rates only during the decade of the War.

To supplement these aggregate patterns, Appendix Tables 2 and 3 present evidence on the impact of the mobilization rate on female weeks worked by age, education and birth cohort. We generally find that WWII mobilization had the greatest impact on the labor supply of high school graduate women, women between the ages of 14-44 and the cohorts that were 15-24 or 35-44 in 1940. Point estimates for the impact of mobilization on the labor supply of women above 54 and those for the cohorts that were 25-34 or 45-54 in 1940 (Appendix Table 3) are sensitive to the inclusion of the aggregate state variables. ${ }^{20}$

Finally, it would be useful to complement these results with evidence on whether women worked relatively more in high-mobilization states during the War years (as well as afterwards). Unfortunately, we are not aware of a data source with information on state labor force participation rates by gender during the intra-Census years. Nevertheless, we can partially complete the picture given by the Census data by investigating whether women worked more in the immediate aftermath of the War (between 1947 and 1950) in high-mobilization states. To do so, we use the CPS Social Security Earnings Records Exact Match file which reports information from Social Security earnings records on quarters worked in covered employment (i.e., private sector, non-self-employed) for adults interviewed for the CPS in March 1978. These data are naturally only available for those who survived to 1978 and report valid Social Security numbers. Because the quarterly employment data do not start until 1947 and contain only the sum of quarters worked for the first three years of the sample (1947 to 1950), we cannot investigate whether women worked more in high-mobilization states during the War. ${ }^{21}$ These data

\footnotetext{
${ }^{20}$ In 1940, the educational distribution of non-elderly, non-farm females was: less than 8th grade, 27 percent; exactly 8th grade, 23 percent; 9-11 years, 22 percent; exactly 12 years, 19 percent; 1 or more additional years beyond high school, 9 percent (3 percentage points of which was accounted for by college graduates). In 1950, the corresponding numbers were $22,17,23,26,12$ and 5 .

${ }^{21}$ Because we do not have information on respondents' state of birth, we use state of residence as an imperfect proxy. Social Security Numbers (SSNs) are essentially only available for women with positive work history and hence we treat missing SSNs as indicating no work history (except in cases where respondents refused to provide a SSN or where the SSN failed to match Social Security data). To attempt to isolate farm workers (who are typically not in covered employment), we variously dropped women in farming occupations, women with farm income, and women residing on farms (and all three). These exclusions had little impact on the results. Note that although the CPS Exact Match file reports annual quarters worked for 1937-1946, these data are imputed
} 
nonetheless provide a rare glimpse at women's employment in the immediate post-war years.

Figure 6 depicts the (standardized) relationship between state mobilization rates and female employment during 1947 and 1950, and separately in each of the years from 1951 to 1977. For women who were ages 16-55 in 1945, we run a regression of total quarters of work in a given period divided by mean quarters of work by women in that period on individual characteristics (age, education, marital status, and a dummy for nonwhite) and the state mobilization rate. The figure plots the coefficients on the mobilization rate measure and the 90 percent confidence interval for each estimate (using STATA robust standard errors clustered by state). The results confirm the patterns detected in the Census data: there is a strong relationship between mobilization rates and female labor employment in 1951, and a weaker but still substantial relationship in 1959 and 1960. Reassuringly, there appears to have been an even more positive relationship between the mobilization rate and female labor supply in the years immediately following the war (1947-1950). Consistent with Goldin's (1991) findings, the impact of the War on female labor supply fades substantially with time, but greater female labor supply in high-mobilization states appears to persist for at least 15 years after the War's end.

\subsection{Supply Shifts or Demand Shifts?}

We have so far interpreted the robust cross-state correlation between mobilization rates and growth in female employment between 1940 and 1950 as indicative of a shift in female labor supply. As Figure 2 shows, the aggregate demand shock, the mobilization for war, that had drawn women into the labor market had almost entirely reversed itself by 1947 . There may still have been post-war differences in the demand for female labor across states correlated with WWII mobilization rates, however. For example, men who served in the War may have had difficulty reintegrating into the workforce, or may have taken advantage of the WWII GI Bill by attaining further education rather than working. If this were the case, greater female labor force participation in high-mobilization states could reflect demand for female labor rather than differences in female labor supply.

To explore these possibilities, Table 8 and Appendix Table 1 also provide estimates of labor supply specifications for males comparable to those estimated for women in Table 4. These models find no significant correlation between WWII mobilization rates and the growth of male from aggregate income data for these years and hence are not useful for our analysis. 
labor supply between 1940 and 1950. Depending on covariates, estimates for male labor supply range from weakly positive to weakly negative and are never significant. As noted above, Panel B of Table 6 also shows no relationship between male labor supply growth and the component of WWII mobilization correlated with non-economic factors (age structure and ethnic mix). Hence, it appears that the net growth in male labor supply between 1940 - 1950 was not systematically lower in high-mobilization states. ${ }^{22}$

To probe the relationship between mobilization and men's employment in 1950 further, the final four columns of Table 8 provide separate labor supply estimates for males who did and did not serve in the War. ${ }^{23}$ These models detect a weak positive relationship between state mobilization and the growth in male labor supply for non-veterans during this decade, but this relationship is insignificant and is only visible in specifications that exclude the interaction between the 1950 dummy and state aggregate measures (farm share, nonwhite population, and educational attainment). For models limited to WWII veterans, there is an insignificant positive effect of mobilization rates on labor supply when we do not control for the state aggregate measures, and an insignificant negative relationship when the state aggregate measures are included. In net, these models do not provide reason to believe that by the $1950 \mathrm{~s}$, male labor supply was systematically affected by state mobilization rates.

As a final piece of evidence, note that Table 9 (discussed below) documents that relative earnings fell for both genders in high- relative to low-mobilization states. If, contrary to our presumption, state-level labor demand shifts induced by WWII mobilization persisted to 1950, we would expect female wages to have risen in high-mobilization states. Similarly, if cross-state variation in female employment were driven by differences in the overall demand for labor in 1950, we would expect both male and female wages to have been higher in high-mobilization states. These wage results therefore suggest that as of 1950, the enduring effects of WWII mobilization were realized primarily through additional female labor supply rather than greater labor demand for either gender (though this last piece of evidence does not imply that there were no demand-side differences across states).

\footnotetext{
${ }^{22}$ See Stanley (1999) and Bound and Turner (1999) on the effects of GI Bills. As noted by Goldin and Margo (1992, footnote 24), college attendance under the WWII GI Bill peaked in 1947 and declined sharply after 1949.

${ }^{23}$ In these specifciations, the 1940 subsample contains all males from the previous columns, while the 1950 subsample is limited to males who report themselves as WWII veterans (columns 6 and 7 ) and non-veterans (columns 8 and 9).
} 


\section{The Impact of Female Labor Supply On Earnings}

The previous section developed the argument that cross-state differences in WWII mobilization rates are a plausible source of variation in female labor supply in 1950. This section exploits this source of variation in female employment to estimate the effect of female supply on a range of labor market outcomes.

\subsection{Initial Evidence}

Figure 4 showed the negative relationship between state WWII mobilization rates and the change in average weekly (log) female and male wages during 1940 and 1950 at the state level. We now investigate these relationships formally.

Table 9 presents our first set of regression estimates for the impact of female labor supply on wages. For the sake of transparency, we initially take the approach of regressing female and male log weekly earnings on our measure of weeks worked by women from the previous section. We present both OLS models and instrumental-variables (IV) estimates in which the female labor supply measure is instrumented by state mobilization rates. Figure 4 above corresponds to the reduced form for the IV estimates (without covariates). More formally, the estimating equation is:

$$
\ln w_{i s t}=\delta_{s}+\gamma_{1950}+X_{i s t}^{\prime} \cdot \beta_{t}+\phi \cdot Y_{s t}+u_{i s t}
$$

The left-hand side variable is log weekly earnings, $\ln w_{i s t}$, while the endogenous regressor is average weeks worked by women in the state of residence of individual $i, Y_{s t}$. In all specifications, we include state of residence dummies, a dummy for 1950, a complete set of education dummies, a quartic in experience, and a dummy for marital status. Models that include nonwhites also include a nonwhite dummy. The coefficient of interest, $\phi$, measures the effect of female labor supply on earnings. As indicated by the time subscript on the coefficient vector, $\beta_{t}$, we allow the wage differential associated with each individual level covariate to differ by decade (similarly to the OLS models of Table 2). Standard errors are again clustered to account for the fact that the labor supply measure operates at the state by year level.

We estimate equation (4) using both OLS and IV/2SLS models. In the IV models, the first-stage equation is analogous to equation (2) above, except that the endogenous variable in this case is not women's individual weeks of work, but average weeks worked per woman 
in each state. This first-stage relationship is tabulated directly below the point estimate in each column. The excluded instrument is the interaction between the 1950 dummy and the mobilization rate. The exclusion restriction implied by this instrumental-variables strategy is that differential mobilization rates affect women's wages across states only through their impact on female labor supply. Based upon the evidence presented in the previous section, we believe that this exclusion restriction is plausible.

It is important to bear in mind that estimates of $\phi$ do not have a direct structural interpretation in terms of our model in Section 2. As the theory underscores, the impact of female labor supply on total male and female earnings should depend upon the (log) ratio of female to male labor supply (as well as the supply of other nonlabor factors). Hence, unless female labor supply (in OLS or instrumented form) is uncorrelated with male labor supply, we cannot directly recover the relevant demand and substitution elasticities from estimates of (4). We therefore view these results as descriptive and adopt a more structural approach in subsequent tables.

In column 1, we begin with a parsimonious specification which indicates that a 1 week increase in female labor supply is associated with a 10.7 percent decline in female weekly earnings. Given that women's labor supply averaged 10.7 weeks in 1940 (Table 1), and assuming no correlation between (instrumented) female labor supply and male labor supply, this point estimate would correspond to a female labor demand elasticity of -1.14. In the next column, we add aggregate measures of female age structure by state to the regression model. These measures control for the correlation between state mobilization rates and female age structure. ${ }^{24}$ Inclusion of age controls reduces the estimated wage impact of female labor supply by approximately 25 percent to -7.0 percentage points for a 1-week increase, which remains highly significant. Column 4 adds the interaction between the 1950 dummy and the 1940 aggregate state measures-share farm, share nonwhite, and average education-thus allowing differential wage growth in farming, high-minority and low-education states. These interactions reduce the magnitude of the estimate by one-third and increase the standard error. The lower panel repeats the results for the white sample with similar results but slightly greater precision. The negative estimated impact of female labor supply on mean female earnings is in all cases significant (in the final specifications, at the 10 percent level) and, as suggested by theory, indicates

\footnotetext{
${ }^{24}$ Female age structure variables measure the share of female state residents ages $14-64$ in each of the following age categories (with one omitted): 14-17, 18-24, 25-34, 45-54, 55-64.
} 
that the demand curve for female labor is downward sloping (at least in the short run).

Comparing these IV estimates to the corresponding OLS estimates in the table, which are typically weakly negative and never significant, suggests that the OLS estimates are likely biased upward (i.e., towards zero). It appears, not surprisingly, that cross-state variation in female labor supply during this decade was jointly determined by a combination of demand and supply shifts. By isolating the component of female employment that is plausibly orthogonal to demand, our IV estimates show a substantially larger effect of female labor supply on female earnings.

The subsequent columns of Table 9 present corresponding estimates for male earnings, both for the full sample and for the white subsample. Contrary to the case of female earnings, theory does not make strong predictions for male earnings: they should decline if male and female labor inputs are close substitutes and nonlabor inputs are supplied inelastically to state labor markets in the short run. In the data, we detect negative effects of female labor supply on male earnings. All point estimates are highly significant except those in the final specifications where we control for the interaction between the 1950 dummy and several state aggregate measures. Interestingly, the estimated effects of female labor supply on male earnings are consistently 30 to 40 percent smaller in absolute magnitude than the corresponding estimates for female earnings. This result suggests that female labor supply is an imperfect substitute for male labor supply, a point which we explore in greater detail below. Once again, the IV estimates are more negative than the corresponding OLS estimates, consistent with the view that OLS estimates are biased towards zero due to simultaneity, and that demand for male and female labor are positively correlated. ${ }^{25}$

The final columns of Table 9 present wage results estimated separately for male WWII veterans and non-veterans. These columns provide an important specification test. If aggregate wage effects for males were driven exclusively by lower wages for veterans, we would be worried about having primarily detected the adverse effects of war reintegration on veterans' earnings. ${ }^{26}$

\footnotetext{
${ }^{25}$ Also notice that the negative effects on female wages are unlikely to be accounted by the labor force participation of women with lower earnings capacity (cf. Smith and Ward, 1984). First, as Appendix Table 2 shows, marginal labor market participants were relatively highly educated, so there is no compelling reason to expect that they will be adversely selected on unobserved skills. Second, to rationalize the wage effect we estimate, i.e., over 10 percent decline in wages in response to a 10 percent increase in employment, with the participation of less skilled women, we would need the marginal participants to earn negative wages!

${ }^{26}$ Angrist and Krueger (1994) present evidence that WWII veterans were positively selected, and Angrist (1990) presents evidence that Vietnam Era veterans experienced earnings losses due to foregone civilian experience.
} 
The estimates in Table 9 indicate significant negative wage effects of female labor supply for both non-veterans and veterans. Interestingly, the point estimates for veterans are somewhat more negative than those of non-veterans. This pattern is consistent with Richard Freeman's "Active Labor Market" hypothesis: veterans, as recent labor market (re-)entrants, may have borne a greater brunt of the wage effects of rising female labor supply.

Appendix Tables 4 estimates models similar to those in Table 9, while controlling for interactions between the 4 Census regions and year, or dropping all Southern state. These results are quite similar to our baseline estimates, indicating that the negative relationship between the mobilization-induced changes in female labor supply and changes in earnings is not driven primarily by Southern states or regional trends.

Given the substantial convergence in regional wage levels that took place among U.S. states during the 1940s (Wright, 1986), we were also concerned that wage patterns detected in Table 9 might reflect a process of "catching up" whereby agricultural states, which generally had low-mobilization rates, gained ground on the rest of the nation during this decade. To check this possibility, we augmented the Table 9 models to control for the 1940 level of wages for the relevant demographic group (interacted with a 1950 dummy). Appendix Table 5 reports the results of this exercise. This lagged wage variable is negative and generally significant indicating that states with initially higher wage levels experienced smaller wage gains during the decade. The important finding however is that the inclusion of the lagged measure does not affect our general conclusions. In models without state aggregate measures, point estimates of the effect of mobilization on wages are lower than the models without lagged wages, but they are higher when the state aggregate measures are included. In all specifications, the effect of mobilization-induced changes in female employment on female wages is statistically significant, and the effect on male wages is always negative, and is significant in all specifications except for those that control for the interactions between the 1950 dummy and aggregate state measures. ${ }^{27}$

\footnotetext{
${ }^{27}$ The results are also unlikely to be driven by institutional changes taking place in the U.S. labor market during this time period. The two major institutional changes of this era are increases in unionization and the imposition, and then removal, of the National War Labor Board (NWLB), which was responsible for approving, and limiting, wage increases.

The NWLB and other price controls are unlikely to be responsible for our results. The NWLB, which was established in January 1942, was dissolved in December 1945, and effectively all wartime price controls were lifted in November 1946 (see Rockoff, 1984), three years before our post-war observations.

We have also estimated the key labor supply and wage models in Tables 4 and 9 while controlling for differential trends in unionization across states during these years (using data from Troy and Sheflin, 1985). Controlling for unionization has little impact on the findings, and a supplemental table of estimates is available on request.
} 


\subsection{Using Mobilization Rates to Estimate Elasticities of Demand and Substitution}

The wage estimates in Table 9 employ average female weeks as the endogenous regressor. This approach will lead to correct estimates of the elasticity of demand or substitution only if (instrumented) female labor supply is uncorrelated with male labor supply. Although this condition may be satisfied, it would be preferable to exploit exogenous variation in male and female labor supply simultaneously. Using a single instrument, we cannot separately identify both sources of variation. We can, however, use the mobilization rate to instrument the (log) ratio of female to male labor supply in a state. This approach surmounts the problem of treating male labor supply as exogenous and thereby brings us closer to the specification suggested by the theoretical model. The equation that we estimate is:

$$
\ln w_{i s t}=\delta_{s}+\gamma_{1950}+f_{i}+X_{i s t}^{\prime} \cdot \beta_{t}^{g}+\chi \cdot \ln \left(\frac{F_{s t}}{M_{s t}}\right)+\eta \cdot f_{i} \cdot \ln \left(\frac{F_{s t}}{M_{s t}}\right)+u_{i s t},
$$

where the sample now includes all individuals (male and female), $f_{i}$ is a dummy for female, $F_{s t}$ is total labor supplied by women and $M_{s t}$ is total labor supplied by men in the state of residence of individual $i$. As indicated by the super- and subscripts on $\beta_{t}^{g}$, each of the individual and state aggregate control measures included in the model (contained in $X_{i s t}$ ) is permitted to impact male and female earnings differentially by gender and decade.

In this equation, there are two coefficients of interest, $\chi$ and $\eta$. The coefficient $\chi$ measures the direct impact of increases in (relative) female labor supply on male and female earnings, and $\eta$ measures the differential effect of female labor supply on female wages. Hence, $\eta$ is an estimate of the inverse elasticity of substitution between male and female labor, and the quantity $\chi+\eta$ is an estimate of the inverse elasticity of demand for female labor.

In the first four columns of Table 10, we present estimates of equation (5) where the labor supply measure is constructed as the log ratio of total female to male weeks supplied in each state and the control variables correspond to those used in the four specifications in Table 9. First-stage estimates, tabulated in each column, indicate that WWII mobilization substantially affected relative gender labor supplies. A 10 percent higher mobilization rate is estimated to have induced a 10 to 20 percent increase in the log ratio of female to male labor supply, an impact which is always precisely estimated and highly significant. ${ }^{28}$

\footnotetext{
${ }^{28}$ This is a sensible magnitude. For example, an increase in the female to male ratio of labor input from 0.30 to 0.35 percent correponds to a $15 \log$ point increase in the this ratio.
} 
We next turn to elasticity estimates. The point estimates in the first two rows of Table 10, corresponding to $\chi$ and $\eta$ in equation (5), are consistently negative, economically sizable, and with few exceptions, highly significant. This set of results confirms the findings above that the demand curve for female labor is downward sloping and that women are relatively close substitutes for men.

Summing $\chi$ and $\eta$ to obtain an estimate of the (inverse) elasticity of demand for female labor, $\sigma_{F}$, we find that a 10 percent increase in relative female labor supply reduced female wages by 6 to 7 percentage points. These wage effects correspond to an own-labor demand elasticity of between -1.4 and -1.7 and are therefore slightly larger in magnitude than the "naive" estimates above. The lower panel of the table presents analogous wage estimates for the subsample of white female wage earners, for whom we find comparable demand elasticities.

The impact of female labor supply on wages is not uniform between the two genders, however. As is visible in the second row of Table 10 (and as was suggested by Table 9), the wage effects of (relative) increases in female labor supply are uniformly more negative for women than they are for men. A 10 percent increase in female labor supply lowers female wages relative to male wages by about 3 percentage points. By implication, female and male labor inputs are highly, but not perfectly, substitutable. In particular, the point estimates for $\eta$, corresponding to the inverse elasticity of substitution $\sigma_{M F}$, imply a substitution elasticity in the range of -3 , with slightly smaller implied elasticities in the models that include aggregate state controls. Again, elasticities are similar in Panel B, where estimates are limited to white males and females.

\subsection{MeAsuring LABOR SUPPly in EFFiCIENCY Units}

As a check on the above results, we also estimate models that replace the aggregate weeks of labor supply measure with a measure of labor supply calculated in efficiency units following the approach of Welch (1969). Conceptually, efficiency unit calculations aggregate various demographic subgroups according to their estimated relative productivities to obtain total labor supply by gender. To implement this approach, we use the 1940 Census sample to calculate average weekly earnings for full-time, full-year workers in the following education by race by gender categories within each state: 5 age categories (13-23, 24-33, 34-43, 44-53, and 54-63); 5 education categories for whites (<8 years, exactly 8 year, between 8 and 12 years, exactly 12 
years, and greater than 12 years of schooling); and 3 education categories for nonwhites $(<5$ years, exactly 5 years to exactly 8 years, and greater than 8 years of completed schooling). ${ }^{29}$ Under the assumption that wages are proportional to marginal productivity, this approach allows us to "quality adjust" aggregate labor input, thereby relaxing the assumption that there is perfect substitutability of labor input within each gender.

Using this matrix of 3,760 efficiency unit weights (47 states by 80 cells), we assign each male and female in our labor supply sample the efficiency weight corresponding to her demographic characteristics and state of residence, $\alpha_{a e r s}^{g}$, where $g$ denotes genders, $a$ indexes age bracket, $e$ indexes education categories, $r$ indexes race, and $s$ indexes states. We calculate aggregate quality-adjusted relative labor supply to a state as

$$
\ln \left(\frac{L_{s}^{f}}{L_{s}^{m}}\right)=\ln \left(\frac{\sum_{a, e, r} \alpha_{\text {aers }}^{f} \cdot F_{\text {aers }}}{\sum_{a, e, r} \alpha_{a e r s}^{m} \cdot M_{a e r s}}\right),
$$

where $F_{\text {aers }}$ is the weeks of labor supplied by females in the state with the relevant demographic characteristics and $M_{\text {aers }}$ is the corresponding quantity for males (and, as always, all calculations use Census sampling weights).

Estimates of equation (5) that use labor supply measured in efficiency units are shown in columns 5-8 of Table 10. The first-stage coefficients from these estimates are slightly smaller in magnitude than the corresponding weeks-based estimates, which may imply that marginal female labor force entrants drawn into the labor market by mobilization had lower average productivity than incumbent participants. We find that the elasticities of demand and substitution calculated from these efficiency-unit based estimates are not systematically different from those estimated using the weeks-worked measure. Hence, these results appear to confirm our previous findings. In the subsequent tables, we employ the weeks-worked measure since it is more transparent.

\footnotetext{
${ }^{29}$ Because non-whites had substantially less schooling than whites in 1940, it was necessary to use fewer education categories with different cutpoints in calculating non-white efficiency units. We normalize each cell by the wages of white, male high school graduates, ages 24-33 in each state in 1940, so each worker's labor input is expressed relative to the weekly full-time labor input of a prime-age white male high school graduate in his or her state. Where cells are empty for given states, we impute them as the population weighted average (normalized) efficiency units of the corresponding cells from other states. Note that the normalization of wages by a given demographic group is for convenience only and does not impact the ratios computed.
} 


\subsection{Differences between Short-Run and Long-Run Elasticities}

As noted in the Introduction and Section 2, the estimates reported in this paper are likely to correspond to short-run elasticities. In general, it is of great interest to know whether shortand long-run elasticities differ substantially. Since, as shown in Figure 3, there was only a small amount of mean reversion in female employment during the 1950s, states with greater WWII mobilization also had greater female employment in 1960. By exploiting the 20-year changes between 1940 and 1960, we can investigate whether the short-run impact of increased female employment is different from its long-run impact. We perform this exercise in Appendix Table 6, by estimating models identical to those in Table 10 except that the two decades we now cover are 1940 and 1960.

Comparing the first-stage coefficients on the mobilization rate interaction between Table 10 and Appendix Table 7, we see that mobilization had a large effect on the growth of relative female labor supply not only between 1940 and 1950, but also between 1940 and 1960. For example, in column 1 of Appendix Table 6, the first-stage coefficient is 2.1, compared to 2.05 in Table 10. However, the standard error is much larger. Thus, not surprisingly, some of the 2SLS estimates will be less precise. Moreover, in models that control for interactions between the 1960 dummy and share of farmers, nonwhites, and average education in 1940, there is no first-stage relationship between mobilization and female employment growth between 1940 and 1960.

The models in Appendix Table 6 that do not control for the state aggregates show that the effect of relative female employment on male wages is broadly comparable between 1940-50 and 1940-60 (columns 1-3 and 5-7). However, the effect of relative female labor supply on malefemale differentials is much weaker for the 20-year state level changes. In fact, the estimates are essentially zero and the standard error bands easily exclude the short-run elasticity estimate from Table 10 (though the main effect, which captures the impact on the level of male and female earnings, is sometimes as large as those in Table 10). This is consistent with the notion that the long-run relative demand curve for women's labor is considerably more elastic than the short-run relative demand curve, or even perhaps perfectly elastic. This could be due to adjustment of nonlabor inputs that are fixed in the short-run (LeChatelier principle), changes in technology or in the organization of production favoring women in areas with greater female employment (Acemoglu, 1998, 2002), or changes in trade patterns that require sufficient time 
to equilibrate.

\section{Does Female Labor Supply Raise Male Earnings Inequality?}

The results above establish that female labor supply lowers male earnings. But this impact need not be uniform throughout the male wage distribution. Indeed, several of the authors cited in the Introduction have argued that rising female labor supply over recent decades is in part responsible for growing male earnings inequality in the U.S. labor market. ${ }^{30}$ Greater female labor supply will generally raise male earnings inequality if women are closer substitutes to low earnings males than high earnings males.

We take three angles of attack to investigate the relationship between female labor supply and male earnings inequality, in all cases exploiting the WWII-induced increase in female employment. First, we ask whether female labor supply affects earnings differentials between males at high, medium and low levels of education - specifically college graduates, high school graduates and those with 8th grade or lower education. ${ }^{31}$ Next, we explore how rising female labor supply changes the level of inequality between various quantiles of the male earnings distribution, for example the 90-50 and 50-10 log earnings ratios. Finally, we ask whether female labor supply also affects residual earnings inequality - that is, the inequality that remains after accounting for observable individual characteristics.

\subsection{The Impact of Female Labor Supply on Male Educational Differentials}

We begin with educational differentials. Consider a variant of equation (5) in which the dependent variable is log weekly earnings of males of two education groups-initially, college and high school graduates, later high school and 8th grade graduates:

$$
\ln w_{i s t}^{m}=\delta_{s}+\gamma_{1950}+c_{i}+X_{i s t}^{\prime} \beta_{t}^{e}+\chi \cdot \ln \left(\frac{F_{s t}}{M_{s t}}\right)+\eta \cdot c_{i} \cdot \ln \left(\frac{F_{s t}}{M_{s t}}\right)+\gamma \ln \left(\frac{C_{s t}^{m}}{H_{s t}^{m}}\right)+u_{i s t} .
$$

\footnotetext{
${ }^{30}$ On rising male earnings inequality see, among many others: Katz and Murphy (1992) and Bound and Johnson (1992) on supply and demand factors; Juhn, Murphy and Pierce (1993) on the role of changing skill premia in the increase in residual inequality; DiNardo, Fortin and Lemieux (1995) and Lee (1999) on the role of labor market institutions; and Berman, Bound and Griliches (1994), Machin and Van Reenan (1998), and Autor, Katz and Krueger (1998) on the role of computerization. Levy and Murnane (1992), Bound and Johnson (1995), Katz and Autor (1999), and Acemoglu (2002) provide surveys of this literature. See the Introduction for cites to studies of the relationship between female labor supply and male earnings inequality.

${ }^{31}$ In 1940, 28 percent of males had less than an 8th grade education, 24 percent had exactly 8 th grade, 22 percent had more than 8th grade but less than high school, 15 percent exactly a high school degree, and the remaining 10 percent had more than high school education (5 percent with college or above). In 1950, the corresponding numbers were $24,18,22,20$, and 15 ( 7 percent with college or above).
} 
In this equation, $c_{i}$ is a dummy for whether individual $i$ is a college graduate (the omitted group being high school graduates), $F_{s t} / M_{s t}$ is relative female labor supply measured in aggregate weeks worked as above, and $C_{s t}^{m} / H_{s t}^{m}$ is the relative supply of college versus high school male labor input. ${ }^{32}$ All covariates are allowed to have different effects on earnings of college and non-college males and to differ by decade.

The coefficients of interest in this equation are $\chi$ and $\eta$. The coefficient $\chi$ measures the impact of female labor supply on the earnings of high school graduates, and $\eta$ gives the effect of female labor supply on the relative wages of college versus high school graduates. Therefore, keeping the employment levels of college and high school graduate males constant, we can think of $\sigma_{f h}=1 / \chi$ as the cross-elasticity of demand between female labor and high school graduates and $\sigma_{f c}=1 /(\chi+\eta)$ as the cross-elasticity of demand between female labor and college graduates. The ratio of cross-elasticities of females for high school versus college graduates, $\sigma_{h c}^{f} \equiv \sigma_{f h} / \sigma_{f c}$, is therefore $(\chi+\eta) / \chi$. If $\sigma_{h c}^{f}$ is less than 1 , this implies that female labor has a more (negative) wage impact on high school graduates, so females are closer substitutes to high school than to college males, and vice versa if $\sigma_{h c}^{f}>1$.

Consistent with our previous results, we anticipate that the main effect of female labor supply on both college and high school wages, $\chi$, is negative. Since relative supplies of male college versus high school graduates, $C_{s t}^{m} / H_{s t}^{m}$, should also directly impact the male college/high school premium, we must either control for this measure or assume that instrumented female labor supply measure is uncorrelated with it. We implement both approaches below and find that the choice is not consequential for our results.

While the college/high school wage differential is of great contemporary interest, the vast majority of males in our 1950 sample (85 percent) had high school or less education, with the two modes of the distribution found at exactly high school completers (20.3 percent) and exactly 8 th grade completers (18.2 percent). Therefore, it is of interest to ask whether female labor supply raised or lowered earnings inequality between these groups of males as well. After estimating equation (7) for the college/high school differential, we perform analogous estimates

\footnotetext{
${ }^{32}$ In models that use the male college/high school relative supply, college labor supply is the sum of total weeks worked supplied by college-plus graduates plus half of those supplied by those with some college; high school labor supply is the sum of weeks worked supplied by high school graduates or less plus half of those supplied by those with some college. In models that use the male high school/8th grade relative supply, high school labor input is the sum of weeks worked supplied by those with high school or more plus half of that supplied by those with more than 8th grade and less than high school education; 8th grade is the sum of weeks worked supplied by those those with 8th grade or less, plus half of that supplied by those with more than 8th grade and less than high school.
} 
for the high school/8th grade differential.

Estimates of equation (7) for college and high school graduates, shown in panel A of Table 11, reveal that growth in female labor supply exerts a small positive effect on male college/high school earnings inequality. A 10 percent increase in female labor supply is predicted to lower male high school wages by 2.5 to 4 log points while reducing college wages by only 1 to 2.5

percentage points. These point estimates imply a relative cross-elasticity of demand $\sigma_{h c}^{f}$ of 0.4 to 0.6 , but this elasticity is imprecisely estimated. This evidence is consistent with the view that females drawn into the labor force by WWII mobilization were more substitutable for high school than college educated men (consistent with the characteristics of female labor force entrants documented in Appendix Table 2). But we cannot reject the hypothesis that women's labor supply reduced college and high school wages by equivalent amounts.

This ambiguity does not carry over to the corresponding results for the impact of female labor supply on the male 8th grade/high school differential. These estimates, found in Panel B of Table 11, have the opposite sign to and are somewhat larger than those for the male college/high school wage premium. They are also more precisely estimated. A 10 percent increase in female labor supply is estimated to reduce male high school relative to 8th grade earnings by 1.5 to 2.5 percentage points. This relative wage impact is highly significant in specifications that do not control for state aggregate measures. In models that include these aggregates, the estimate is of similar magnitude but is less precise. Interestingly, we cannot reject the hypothesis that female labor supply had no impact on the wages of 8th grade males.

In net, the primary impact of increased female labor supply on male educational inequality during the 1940s was to lower the wages of male high school graduates relative to more-educated males, and particularly relative to less-educated males. This suggests that during the WWII era, females were closer substitutes to males at the middle of the skill distribution than to males in either of the tails. Given that low-educated males in 1950 were reasonably likely to be employed in manual occupations, it is plausible that women would indeed be worse substitutes for them than for their high school graduate brethren. This result stands in some contrast to Grant and Hamermesh's (1981) and Topel's (1994) OLS findings that high-skill women are strong substitutes for low-skill males. Of course, our findings are from another era and these substitution parameters need not be fixed over long intervals. 


\subsection{The Impact of Female Labor Supply on the Distribution of Male Earnings}

Because women's labor force entry during the 1940s appears to have raised earnings inequality between college and high school males while lowering it for high school versus 8th grade educated males, the net impact on male inequality is - at this point - ambiguous. Educational inequality is however only one component of earnings differentials, and the total impact of female labor supply on male inequality could in principle be quite different than its impact on educational inequality.

To provide a more complete picture of these potential effects, we adopt a less structural approach. Using observed male earnings distributions and estimated residual male earnings distributions by state, we define state level inequality metrics as the log difference between various quantiles of the earnings or residual earnings distribution, such as the 90-50 or 50-10 differential. We then explore whether WWII-induced increases in female labor supply raised or lowered these inequality measures. To implement this approach, we first estimate standard wage regressions of the form:

$$
\ln w_{i s t}=\delta_{s}+\gamma_{1950}+X_{i s t}^{\prime} \cdot \beta_{t}+v_{i s t}
$$

where $w_{i t}$ is weekly earnings for male $i$ residing in state $s$ in year $t$. In the "overall inequality" specification, we include only state dummies and a year main effect. In the "residual inequality" model, the vector $X_{i s t}$ includes a full set of education dummies, a quartic in potential experience, nonwhite, state of residence, state or country of birth, veteran status, and marital status dummies, as well as controls for state female age structure by year. A third set of models add state-level macro controls (share farmer and nonwhite, and average education in 1940). The fact that $\beta_{t}$ is indexed by $t$ indicates that returns to these observed characteristics are allowed to vary by decade. We also briefly look at measures of wage inequality that combine workers from both genders.

The measures of overall or residual inequality are calculated separately in each state and year as the difference between the 90 th and the 10th (or 50th and 10th, etc.) percentile values

of the corresponding residual distribution, $v_{i s t}$, and are denoted by $v_{s t}^{90-10}$ etc. Observe that the residual distribution in the "overall" inequality model is simply the demeaned log earnings distribution in each state.

We then use these inequality measures as the left-hand side variable in Table 12 . The typical 
regression takes the form:

$$
v_{s t}^{90-10}=\delta_{s}+\gamma_{1950}+\phi \cdot \ln \left(\frac{F_{s t}}{M_{s t}}\right)+u_{i s t}
$$

where $v_{s t}^{90-10}$ is the 90-10 differential, the endogenous regressor, $F_{s t} / M_{s t}$ is again relative female labor supply (in weeks), and the instrument is the state mobilization rate, $m_{s}$, interacted with the 1950 dummy. To move from micro- to macro-data (i.e., from individual Census observations to state level aggregates) without losing the information provided by the micro-level controls, we orthogonalize both the instrumental variable and the endogenous regressor with respect to all of the covariates in $X_{i s t}$ to form the state level measures used in the second stage of estimation.

The first column in Table 12 labeled Mean $\Delta$ provides estimates of mean state-level change in earnings inequality from 1940 to 1950. The sizable decline in earnings inequality visible in the table reflects the well-known "Great Compression" studied by Goldin and Margo (1992). Over the decade of the War, male 90-50 and 50-10 differentials each declined by close to 17 log points.

The first set of regression estimates in specification 1 examines the state-level relationship between growth in the log relative supply of female labor input (instrumented with the mobilization rate) and the contemporaneous change in overall state level earnings inequality. The net impact of female labor supply on male earnings inequality is positive and sizable. A 10 percent increase in female labor input is estimated to widen the 90-10 earnings differential by $5.5 \mathrm{log}$ points, which is highly significant. It is noteworthy that this entire impact occurs in the upper half of the male earnings distribution. Consistent with our findings for the impact of female labor supply on the wage gap between middle- and low-education males, increases in female labor supply appear to cause some compression below the median of the distribution, though this impact is not significant. An interesting implication of these estimates is that without the WWII-induced increase in female labor force participation the "Great Compression" would have been even "greater" in the sense that wage inequality among males would have declined even further between 1940 and 1950. ${ }^{33}$

\footnotetext{
${ }^{33}$ Interestingly and consistent with our findings, Goldin and Margo (1992, p. 27) notice a similar pattern of widening inequality in industries with high female employment: "Industries that were female-intensive (cigars, men's neckwear, woolen and worsted mills) comprise an obvious exception [to the trend of wage compression]... Rather than experiencing a narrowing of the wage structure from the prewar to the wartime or postwar periods, their distributions actually widened."
} 
When we look at the impact of female labor force participation on wage inequality among all workers (male and female) in Panel C, we find much larger effects. Now a 10 percent increase in female labor supply widens the 90-10 earnings differential by 1.4 log points. This much larger effect is not surprising; greater female participation both increases male wage inequality directly, as we have already established, and also adds more women to the distribution who, at this time, were paid considerably less than men.

Panel B of the table presents comparable estimates for the white subsample. In this case the impact of female labor supply on inequality above the median is somewhat less positive while the impact on inequality below the median is somewhat more negative. This estimate suggests that female labor supply primarily reduces male earnings at a lower point in the white male earnings distribution than in the overall earnings distribution, which appears plausible given the substantial racial disparities in education and earnings in this period.

The subsequent two columns of Panels A and B present estimates of the impact of female labor supply on residual male inequality. The impact of female labor supply on residual inequality is about half as large as the impact on overall inequality, but still sizable. A 10 percent increase in female labor supply is estimated to raise the male 90-10 earnings differential by 1.5 to 2 log points. The columns numbered (2) present residual estimates in which state level macro controls (share nonwhite and farm, and average education) are included in the first stage models. The point estimates are typically less precise than previous estimates.

Overall, the results reported in this section show a substantial effect of female employment growth on overall and residual inequality among men at midcentury. These results therefore provide some support to the hypotheses advanced in Fortin and Lemieux (2000) and Topel (1994 and 1997), linking female labor supply to rising male inequality - though distinct from the hypotheses of these authors, female labor appears to increase male inequality not by competing with low-skill males, but by increasing dispersion at the top of the male wage distribution. Interestingly, the effects we find are large enough to "explain" a large fraction of the recent increase in male wage inequality as resulting from the concurrent sizable rise in female employment. This conclusion may be premature, however, for two reasons: first, the education levels and characteristics of women who increased their labor supply during the decade differ substantially from those of the marginal female labor market participants of today. The structure of production has also changed substantially since midcentury. Accordingly, substitution elastici- 
ties we estimate from midcentury may not be directly comparable to the elasticities today. And second, as noted before, our estimates correspond to short-run elasticities, which may be quite different from long-run elasticities as the results in Appendix Table 6 suggest. ${ }^{34}$ To understand the effect of female employment on the increase in male wage inequality over the past three decades, the relevant elasticities are long-run elasticities. Work exploiting additional sources of variation in recent female employment growth is necessary to make progress on uncovering the links between rising female labor supply and recent changes in the structure of earnings.

\section{Conclusion}

The epochal rise in female labor force participation is one of the most profound labor market transformations of the past century. And yet, the economics profession knows relatively little about the labor market consequences of increased female labor force participation. An empirical investigation of this issue requires a source of variation in female employment that is orthogonal to demand for female (and also male) labor.

In this paper, we developed the argument that the differential extent of mobilization for WWII across U.S. states provides a useful source of variation to identify the effects of women's labor force participation on a range of labor market outcomes. We documented that in 1950 women participated more in states where a larger fraction of working-age males served in the military during the mid-1940s. This differential female labor supply behavior does not seem to be accounted for by other cross-state differences or possible demand factors, and is not present in the 1940 data. We interpret this as a shift in female labor supply induced by the mobilization for the War.

Using this source of variation, we estimate the effect of greater female participation on female and male wages, returns to education, and wage inequality among men. Our results indicate more downward sloping demand curves for female labor, and a closer degree of substitutability between males and females than suggested by OLS estimates, presumably because OLS regressions are biased towards-zero by simultaneous demand-induced variation in female employment. We also find that, contrary to a common hypothesis in the literature, women are not the closest substitutes to the lowest education males, but to high school graduate males (at

\footnotetext{
${ }^{34}$ In addition, as noted by, among others, Blau and Kahn (1994, 1997), the gender wage gap closed substantially during the 1980 s as female employment was rising, suggesting that demand shifts favoring women may be an important component of the rise in female labor supply.
} 
least at midcentury). Nevertheless, because greater female participation increases inequality in the top half of the male wage distribution, our estimates suggest sizable effects of female labor force participation on male wage inequality. This finding indicates that a more detailed investigation of the relationship between the increase in female labor supply and the recent widening inequality among males would be fruitful.

\section{REFERENCES}

Acemoglu, Daron (1998)," "Why Do New Technologies Complement Skills? Directed Technical Change and Wage Inequality" Quarterly Journal of Economics, 113(4), November, 1055-1090.

Acemoglu, Daron. (2002), "Technical Change, Inequality and the Labor Market." Journal of Economic Literature, 40, March, 7 - 72.

Acemoglu, Daron and Joshua D. Angrist (2000) "How Large Are Human Capital Externalities? Evidence from Compulsory Schooling Laws" NBER Macro Annual 2000, pp. 9-71.

Angrist, Joshua D. (1990), "Lifetime Earnings and the Vietnam Era Draft Lottery: Evidence from Social Security Earnings Records." American Economic Review, 80(3), June, 313 - 336.

Angrist, Joshua D. and Guido W. Imbens. (1995), "Two-Stage Least Squares Estimation of Average Causal Effects in Models with Variable Treatment Intensity." Journal of the American Statistical Association, 90(430), June, 431 - 442.

Angrist, Joshua D. and Alan B. Krueger (1994), "Why Do World War II Veterans Earn More than non-Veterans?" Journal of Labor Economics, 12(1), January, 74 - 97.

Autor, David H., Lawrence F. Katz and Alan B. Krueger (1998), "Computing Inequality: Have Computers Changed the Labor Market?" Quarterly Journal of Economics, 113(4), November, 1169 - 1214 .

Autor, David H., Frank Levy and Richard J. Murnane (2001), "The Skill Content of Recent Technological Change: An Empirical Exploration." NBER Working Paper No. 8337, June.

Berman, Eli, John Bound and Zvi Griliches (1994), "Changes in the Demand for Skilled Labor within U.S. Manufacturing: Evidence from the Annual Survey of Manufacturers" Quarterly Journal of Economics, 109(2), May, 367-397.

Bernard, Andew B., J. Bradford Jensen and Peter Schott (2001), "Factor Price Equality and The Economies of the United States." NBER Working Paper \# 8068.

Blanchard, Olivier Jean and Lawrence F. Katz (1992), "Regional Evolutions" Brookings 
Papers on Economic Activity, 1, 1 - 75.

Blau, Francine and Lawrence Kahn (1994), "Rising Wage Inequality and the U.S. Gender Gap." American Economic Review, v84, n2, 23-28.

Blau, Francine and Lawrence Kahn (1997), "Swimming Upstream: Trends in the Gender Wage Differential in 1980s." Journal of Labor Economics, v15, n1, 1-42.

Blau, Francine and Lawrence Kahn (2000), "Gender Differences in Pay." Journal of Economic Perspectives, v14, n4, 75-99.

Blau, Francine, Marianne Ferber and Anne Winkler (2002), The Economics of Women, Men and Work. Upper Saddle River, New Jersey: Prentice Hall.

Bound, John and Harry Holzer (2000, "Demand Shifts, Population Adjustments, and Labor Market Outcomes during the 1980s." Journal of Labor Economics, 18(1), 20 - 54.

Bound, John and George Johnson (1992), "Changes in the Structure of Wages in the 1980's: An Evaluation of Alternative Explanations." American Economic Review, v82, n3, 371-92.

Bound, John and George Johnson (1995), "What Are the Causes of Rising Wage Inequality in the United States?" Federal Reserve Bank of New York Economic Policy Review, v1, n1, 9-17.

Bound, John and Sarah E. Turner (1999), "Going to War and Going to College: Did World War II and the G.I. Bill Increase Educational Attainment for Returning Veterans?" NBER Working Paper \#7452, December.

Card, David and John DiNardo (2000, "Do Immigrant Inflows Lead to Native Outflows?" American Economic Review Papers and Proceedings, 90(2), 360 - 367.

Clark, Kim B. and Lawrence H. Summers, (1982) "Labour Force Participation: Timing and Persistence" Review of Economic Studies, 49(5), 825-844.

DiNardo, John, Nicole Fortin and Thomas Lemieux (1996), "Labor Market Institutions and the Distribution of Wages, 1973-1992: A Semiparametric Approach." Econometrica, v64, n5, $1001-44$.

Dresser, Laura (1994), "Changing Labor Market Opportunities of White and AfricanAmerican Women in the 1940s and the 1980s." unpublished dissertation, University of Michigan.

Goldin, Claudia (1990), Understanding the Gender Gap: An Economic History of American Women. Oxford: Oxford University Press. 
Goldin, Claudia (1991), "The Role of World War II in the Rise of Women's Work." American Economic Review, 81(4), September, $741-756$.

Goldin, Claudia (1994), "Labor Markets in the Twentieth Century." NBER Working Paper, Series on Historical Factors in Long Term Growth \#58, June.

Goldin, Claudia and Robert A. Margo (1992), "The Great Compression: The Wage Structure in the United States at Mid-Century." Quarterly Journal of Economics, 112, 1-34.

Grant, James H. and Daniel S. Hamermesh (1981), "Labor Market Competition among Youths, White Women and Others" Review of Economics and Statistics, 63, pp. 354-360.

Hanson, Gordon and Matthew Slaughter, (2002 forthcoming) "Labor Market Adjustment in Open Economies: Evidence From U.S. States." Journal of International Economics.

Jaeger, David A. (1997), "Reconciling the Old and New Census Bureau Education Questions: Recommendations for Researchers." Journal of Business and Economic Statistics, 15(3), July, 300-309.

Juhn, Chinhui and Dae Il Kim (1999), "The Effects of Rising Female Labor Supply on Male Wages." Journal of Labor Economics, v17, n1, 23-48.

Juhn, Chinhui, Kevin Murphy and Brooks Pierce (1993), "Wage Inequality and the Rise in Returns to Skill." Journal of Political Economy, v101, 410-42.

Katz, Lawrence and David Autor (1999), "Changes in the Wage Structure and Earnings Inequality." in Orley Ashenfelter and David Card, eds., Handbook of Labor Economics, Volume 3A, Amsterdam: Elsevier-North Holland, 1463-1555.

Katz, Lawrence and Kevin Murphy (1992), "Changes in Relative Wages, 1963-1987: Supply and Demand Factors." Quarterly Journal of Economics,107 (1), 35-78.

Krusell, Per, Lee E. Ohanian, José Víctor Ríos-Rull, Gionvanni L. Violante (2000), "Capitalskill Complimentarity and Inequality: A Macroeconomic Analysis." Econometrica, 68(5), 1029 $-1053$.

Levy, Frank and Richard Murnane (1992), "U.S. Earnings Levels and Earnings Inequality: A Review of Recent Trends and Proposed Explanations." Journal of Economic Literature, v30, n3, 1333-81.

Machin, Stephen and John Van Reenen (1998), "Technology and Changes in Skill Structure: Evidence from Seven OECD Countries." Quarterly Journal of Economics, 113 (4), November, $1215-1244$. 
Moretti, Enrico (2000), "Estimating the Social Return to Education: Evidence From Longitudinal and Cross-Sectional Data," Center for Labor Economics, University of California, Berkeley, Working Paper No. 22.

O'Neill, June and Solomon Polachek (1993), "Why the Gender Gap in Wages Narrowed in the 1980s." Journal of Labor Economics, v11, n1, 205-28.

Samuelson, Paul (1947) The Foundations of Economic Analysis, Cambridge, MA, Harvard University Press.

Samuelson, Paul (1948) "International Trade and Equalization of Factor Prices" Economics Journal, 58, 163-84.

Selective Service System (1956), "Special Monographs \#1-18." Washington D.C.: U.S. Government Printing Office.

James P. Smith and Michael P. Ward (1984), "Women's Wages and Work in the Twentieth Century." Rand, R-3119-NICHD, October.

Stanley, Marcus (1999), "The Mid-Century GI Bills and Higher Education," Working Paper, Case Western Reserve University.

Topel, Robert H. (1994), "Wage Inequality and Regional Labour Market Peformance in the U.S." in Toshiaki Tachibanaki, ed., Labour Market and Economic Performance: Europe, Japan and the USA, New York: St. Martin's Press, $93-127$.

Topel, Robert H. (1997), "Factor Proportions and Relative Wages: The Supply-Side Determinants of Wage Inequality." Journal of Economic Perspectives, 11(2), Spring, 55 - 74.

Troy, Leo and Neil Sheflin (1985), U.S. Union Sourcebook: Membership, Finances, Structure, Directory, New Jersey: IRDIS, Industrial Relations and Information Services.

U.S. Bureau of the Census (1975), "Historical Statistics of the United States." Washington, D.C.: U.S. Government Printing Office.

Welch, Finis (1969), "Linear Synthesis of Skill Definition." Journal of Human Resources, $4(3), 311-327$.

Welch, Finis (2000), "Growth in Women's Relative Wages and in Inequality among Men: One Phenomenon or Two?" American Economic Review, v90, n2, 444-49.

Williams, Constance (1949) "The Status of Women Workers," in Colston E. Warne et al., eds. Labor in Postwar America (New York: Remsen Press, 1949).

Wright, Gavin (1986) Old South, New South (New York: Basic Books). 
Table 1: Characteristics of U.S. State Residents in Low, Medium and High Mobilization Rate States 1940, 1950, and 1960

\begin{tabular}{|c|c|c|c|c|c|c|c|c|c|c|c|c|}
\hline \multirow[b]{4}{*}{ Weeks Worked } & \multicolumn{4}{|c|}{1940} & \multicolumn{4}{|c|}{1950} & \multicolumn{4}{|c|}{1960} \\
\hline & All & Low & Med. & High & All & Low & Med. & High & All & Low & Med. & High \\
\hline & \multicolumn{12}{|c|}{ A. Non-Farm Females Ages $14-64$} \\
\hline & $\begin{array}{l}11.2 \\
(1.7)\end{array}$ & $\begin{array}{l}10.9 \\
(1.6)\end{array}$ & $\begin{array}{l}11.3 \\
(1.8)\end{array}$ & $\begin{array}{l}11.4 \\
(1.8)\end{array}$ & $\begin{array}{l}13.7 \\
(1.7)\end{array}$ & $\begin{array}{l}12.8 \\
(1.6)\end{array}$ & $\begin{array}{l}13.9 \\
(1.6)\end{array}$ & $\begin{array}{l}14.4 \\
(1.6)\end{array}$ & $\begin{array}{l}16.6 \\
(1.5)\end{array}$ & $\begin{array}{l}15.8 \\
(1.4)\end{array}$ & $\begin{array}{l}16.8 \\
(1.6)\end{array}$ & $\begin{array}{l}17.2 \\
(1.4)\end{array}$ \\
\hline $\begin{array}{l}\text { Log Weekly } \\
\text { Earnings }\end{array}$ & $\begin{array}{c}2.61 \\
(0.27)\end{array}$ & $\begin{array}{c}2.33 \\
(0.29)\end{array}$ & $\begin{array}{c}2.67 \\
(0.20)\end{array}$ & $\begin{array}{l}2.76 \\
(0.14)\end{array}$ & $\begin{array}{c}3.60 \\
(0.16)\end{array}$ & $\begin{array}{l}3.45 \\
(0.19)\end{array}$ & $\begin{array}{c}3.64 \\
(0.10)\end{array}$ & $\begin{array}{c}3.66 \\
(0.11)\end{array}$ & $\begin{array}{l}4.06 \\
(0.16)\end{array}$ & $\begin{array}{c}3.92 \\
(0.18)\end{array}$ & $\begin{array}{c}4.08 \\
(0.12)\end{array}$ & $\begin{array}{c}4.15 \\
(0.11)\end{array}$ \\
\hline Mean Age & $\begin{array}{l}35.8 \\
(1.1)\end{array}$ & $\begin{array}{l}34.9 \\
(1.2)\end{array}$ & $\begin{array}{l}36.0 \\
(0.9)\end{array}$ & $\begin{array}{l}36.5 \\
(0.7)\end{array}$ & $\begin{array}{l}37.3 \\
(1.0)\end{array}$ & $\begin{array}{l}36.4 \\
(1.0)\end{array}$ & $\begin{array}{l}37.7 \\
(1.0)\end{array}$ & $\begin{array}{l}37.8 \\
(0.5)\end{array}$ & $\begin{array}{l}38.0 \\
(0.8)\end{array}$ & $\begin{array}{l}37.4 \\
(0.6)\end{array}$ & $\begin{array}{l}38.3 \\
(0.9)\end{array}$ & $\begin{array}{l}38.3 \\
(0.6)\end{array}$ \\
\hline \multirow[t]{2}{*}{$\begin{array}{l}\text { Mean Year of } \\
\text { Schooling }\end{array}$} & $\begin{array}{c}9.0 \\
(0.7)\end{array}$ & $\begin{array}{c}8.5 \\
(0.9)\end{array}$ & $\begin{array}{l}9.1 \\
(0.4)\end{array}$ & $\begin{array}{c}9.4 \\
(0.6)\end{array}$ & $\begin{array}{c}9.7 \\
(0.7)\end{array}$ & $\begin{array}{c}9.2 \\
(0.8)\end{array}$ & $\begin{array}{c}9.8 \\
(0.3)\end{array}$ & $\begin{array}{l}10.1 \\
(0.5)\end{array}$ & $\begin{array}{l}10.4 \\
(0.5)\end{array}$ & $\begin{array}{l}10.0 \\
(0.6)\end{array}$ & $\begin{array}{l}10.4 \\
(0.3)\end{array}$ & $\begin{array}{l}10.7 \\
(0.4)\end{array}$ \\
\hline & \multicolumn{12}{|c|}{ B. Non-Farm Males Ages 14 - 64} \\
\hline Weeks Worked & $\begin{array}{l}34.3 \\
(1.7)\end{array}$ & $\begin{array}{l}34.2 \\
(1.4)\end{array}$ & $\begin{array}{l}34.6 \\
(1.6)\end{array}$ & $\begin{array}{l}34.1 \\
(2.0)\end{array}$ & $\begin{array}{l}38.7 \\
(1.6)\end{array}$ & $\begin{array}{l}38.3 \\
(2.0)\end{array}$ & $\begin{array}{l}39.1 \\
(1.7)\end{array}$ & $\begin{array}{l}38.5 \\
(1.1)\end{array}$ & $\begin{array}{l}40.1 \\
(1.6)\end{array}$ & $\begin{array}{l}38.8 \\
(1.7)\end{array}$ & $\begin{array}{l}40.3 \\
(1.5)\end{array}$ & $\begin{array}{l}40.8 \\
(1.2)\end{array}$ \\
\hline $\begin{array}{l}\text { Log Weekly } \\
\text { Earnings }\end{array}$ & $\begin{array}{c}3.23 \\
(0.18)\end{array}$ & $\begin{array}{c}3.07 \\
(0.24)\end{array}$ & $\begin{array}{c}3.27 \\
(0.12)\end{array}$ & $\begin{array}{c}3.32 \\
(0.08)\end{array}$ & $\begin{array}{c}4.07 \\
(0.13)\end{array}$ & $\begin{array}{c}3.96 \\
(0.18)\end{array}$ & $\begin{array}{c}4.09 \\
(0.08)\end{array}$ & $\begin{array}{l}4.13 \\
(0.08)\end{array}$ & $\begin{array}{l}4.60 \\
(0.14)\end{array}$ & $\begin{array}{c}4.49 \\
(0.19)\end{array}$ & $\begin{array}{c}4.62 \\
(0.09)\end{array}$ & $\begin{array}{l}4.67 \\
(0.08)\end{array}$ \\
\hline Mean Age & $\begin{array}{l}35.8 \\
(1.2)\end{array}$ & $\begin{array}{l}34.7 \\
(1.4)\end{array}$ & $\begin{array}{l}36.2 \\
(1.0)\end{array}$ & $\begin{array}{l}36.4 \\
(0.7)\end{array}$ & $\begin{array}{l}37.4 \\
(1.1)\end{array}$ & $\begin{array}{l}36.4 \\
(1.2)\end{array}$ & $\begin{array}{l}37.7 \\
(0.9)\end{array}$ & $\begin{array}{l}37.8 \\
(0.6)\end{array}$ & $\begin{array}{l}37.7 \\
(1.1)\end{array}$ & $\begin{array}{l}36.8 \\
(1.1)\end{array}$ & $\begin{array}{l}38.1 \\
(1.0)\end{array}$ & $\begin{array}{l}38.1 \\
(0.8)\end{array}$ \\
\hline \multirow[t]{3}{*}{$\begin{array}{l}\text { Mean Year of } \\
\text { Schooling }\end{array}$} & $\begin{array}{c}9.1 \\
(0.6)\end{array}$ & $\begin{array}{c}8.6 \\
(0.8)\end{array}$ & $\begin{array}{c}9.2 \\
(0.3)\end{array}$ & $\begin{array}{c}9.4 \\
(0.5)\end{array}$ & $\begin{array}{c}9.7 \\
(0.7)\end{array}$ & $\begin{array}{l}9.1 \\
(0.8)\end{array}$ & $\begin{array}{c}9.8 \\
(0.4)\end{array}$ & $\begin{array}{l}10.1 \\
(0.5)\end{array}$ & $\begin{array}{l}10.4 \\
(0.6)\end{array}$ & $\begin{array}{c}9.8 \\
(0.6)\end{array}$ & $\begin{array}{l}10.4 \\
(0.3)\end{array}$ & $\begin{array}{l}10.8 \\
(0.4)\end{array}$ \\
\hline & \multicolumn{12}{|c|}{ C. State Aggregates: Males Ages 13-44 in 1940} \\
\hline & $\begin{array}{c}\text { Perce } \\
\text { All }\end{array}$ & $\begin{array}{l}\text { nt Mobi } \\
\text { Low }\end{array}$ & $\begin{array}{l}\text { lized } 19 \\
\text { Med. }\end{array}$ & $\begin{array}{c}940-47 \\
\text { High }\end{array}$ & $\begin{array}{l}\text { She } \\
\text { All }\end{array}$ & $\begin{array}{l}\text { are Farr } \\
\text { Low }\end{array}$ & $\begin{array}{l}\text { mers } 19 \\
\text { Med. }\end{array}$ & $\begin{array}{l}940 \\
\text { High }\end{array}$ & $\begin{array}{l}\text { Shar } \\
\text { All }\end{array}$ & $\begin{array}{l}\text { re Non- } \\
\text { Low }\end{array}$ & $\begin{array}{l}\text { White } 1 \\
\text { Med. }\end{array}$ & $\begin{array}{l}1940 \\
\text { High }\end{array}$ \\
\hline $\begin{array}{c}\text { Percent } \\
\text { Mobilization }\end{array}$ & $\begin{array}{l}47.8 \\
(3.2)\end{array}$ & $\begin{array}{l}44.0 \\
(1.4)\end{array}$ & $\begin{array}{l}47.6 \\
(1.0)\end{array}$ & $\begin{array}{l}51.5 \\
(1.9)\end{array}$ & $\begin{array}{c}13.4 \\
(10.8)\end{array}$ & $\begin{array}{c}23.9 \\
(10.2)\end{array}$ & $\begin{array}{l}11.4 \\
(8.8)\end{array}$ & $\begin{array}{c}6.9 \\
(6.4)\end{array}$ & $\begin{array}{c}8.6 \\
(10.1)\end{array}$ & $\begin{array}{c}16.8 \\
(15.2)\end{array}$ & $\begin{array}{c}6.9 \\
(5.8)\end{array}$ & $\begin{array}{l}3.6 \\
(2.1)\end{array}$ \\
\hline
\end{tabular}

Cross-state standard deviations in parenthesis. Data are from Selective Service (1956) monographs and Census PUMS one percent samples for 1940, 1950 (sample line subsample), and 1960. State mobilization rate is the number of males serving in WWII divided by the number registered ages 18-44 during the draft years. The Census PUMS sample includes those ages 14-64 (in earnings year), not living in institutional groups quarters, not employed in farming, and residing in the continental United States excluding D.C. and Nevada. There are 16 states in the low mobilization category (mobilization rate < 45\%: GA, ND, NC, SD, SC, WI, LA, AL, AR, MS, VA, TN, KY, IN, MI, IA,), 15 states in the medium category (mobilization rate $\geq 45 \%$ and $<49 \%$ : MO, TX, NE, MN, MD, DE, VT, IL, FL, NM, $\mathrm{OH}, \mathrm{WV}, \mathrm{NY}, \mathrm{WY}, \mathrm{OK}$ ), and 16 states in the high category (mobilization rate $\geq 49 \%$ : KS, MT, CT, AZ, CO, NJ, ID, CA, ME, WA, PA, UT, NH, OR, RI, MA.) Earnings samples include workers in paid employment excluding selfemployed who earned between $\$ 0.50$ and $\$ 250$ an hour in 1990 dollars during the previous year (deflated by CPI All Urban Consumers series CUUR0000SA0) and worked at least 35 hours in the survey reference week and 40 weeks in the previous year. Top coded values are imputed as 1.5 times the censored value. Average years of schooling is calculated using highest grade completed. Share non-white and farm are the fraction males in each state ages 1344 in 1940 with these characteristics (including farm population). 
Table 2. OLS Estimates of Impact of Female Labor Supply on Earnings 1940 - 1990 at Various Time Intervals

Dependent Variable: Log Weekly Earnings of Full-Time Workers

Sample: All Full Time Workers

\begin{tabular}{|c|c|c|c|c|c|c|c|c|}
\hline & \multicolumn{4}{|c|}{ A. Female Weekly Earnings } & \multicolumn{4}{|c|}{ B. Male Weekly Earnings } \\
\hline & $\begin{array}{c}1940-90 \\
(1)\end{array}$ & $\begin{array}{c}1970-90 \\
(2)\end{array}$ & $\begin{array}{c}1940-60 \\
(3)\end{array}$ & $\begin{array}{c}1940-50 \\
(4) \\
\end{array}$ & $\begin{array}{c}1940-90 \\
(1)\end{array}$ & $\begin{array}{c}1970-90 \\
(2)\end{array}$ & $\begin{array}{c}1940-60 \\
(3)\end{array}$ & $\begin{array}{c}1940-50 \\
(4)\end{array}$ \\
\hline $\begin{array}{l}\text { Weeks Worked } \\
\text { per Woman }\end{array}$ & $\begin{array}{c}0.008 \\
(0.005)\end{array}$ & $\begin{array}{l}-0.004 \\
(0.004)\end{array}$ & $\begin{array}{c}0.016 \\
(0.008)\end{array}$ & $\begin{array}{l}-0.006 \\
(0.011)\end{array}$ & $\begin{array}{l}-0.008 \\
(0.003)\end{array}$ & $\begin{array}{l}-0.011 \\
(0.003)\end{array}$ & $\begin{array}{l}-0.001 \\
(0.006)\end{array}$ & $\begin{array}{l}-0.008 \\
(0.006)\end{array}$ \\
\hline $\mathrm{R}^{2}$ & 0.88 & 0.70 & 0.74 & 0.64 & 0.89 & 0.67 & 0.74 & 0.58 \\
\hline \multirow[t]{3}{*}{$\mathrm{n}$} & 338,322 & 417,019 & 152,428 & 78,094 & 545,483 & 694,219 & 413,793 & 213,966 \\
\hline & \multicolumn{4}{|c|}{ C. Male College/High School Differential } & \multicolumn{4}{|c|}{ D. Male 90-10 Differential } \\
\hline & $\begin{array}{c}1940-90 \\
(1)\end{array}$ & $\begin{array}{c}1970-90 \\
(2)\end{array}$ & $\begin{array}{c}1940-60 \\
(3)\end{array}$ & $\begin{array}{c}1940-50 \\
(4) \\
\end{array}$ & $\begin{array}{c}1940-90 \\
(1)\end{array}$ & $\begin{array}{c}1970-90 \\
(2)\end{array}$ & $\begin{array}{c}1940-60 \\
(3)\end{array}$ & $\begin{array}{c}1940-50 \\
(4)\end{array}$ \\
\hline $\begin{array}{l}\text { Weeks Worked } \\
\text { per Woman }\end{array}$ & $\begin{array}{l}-0.010 \\
(0.004)\end{array}$ & $\begin{array}{l}-0.010 \\
(0.004)\end{array}$ & $\begin{array}{l}-0.004 \\
(0.006)\end{array}$ & $\begin{array}{l}-0.003 \\
(0.006)\end{array}$ & $\begin{array}{c}0.016 \\
(0.016)\end{array}$ & $\begin{array}{l}-0.017 \\
(0.013)\end{array}$ & $\begin{array}{c}0.033 \\
(0.048)\end{array}$ & $\begin{array}{c}0.037 \\
(0.012)\end{array}$ \\
\hline $\mathrm{R}^{2}$ & 0.83 & 0.65 & 0.71 & 0.55 & 0.64 & 0.92 & 0.63 & 0.98 \\
\hline $\mathrm{n}$ & 274,238 & 376,878 & 143,031 & 60,445 & 94 & 94 & 94 & 94 \\
\hline
\end{tabular}

Standard errors in parentheses account for clustering on state and year of observation. Each coefficient in Panels A $\mathrm{C}$ is from a pooled microdata regression of the independent variable of interest from the two relevant decades regressed on average female weeks worked by state. Additional controls include a quartic in potential experience, a year main effect, a constant, and dummies for: non-white, age, marital status, state/country of birth, state of residence, and years of completed education. All individual demographic variables, aside from state of residence/birth, are also interacted with a year dummy. Birthplace dummies correspond to state of birth (if U.S. born) or German, Italian, Japanese, Other European, Other Asian, African, Latin American, and Other. Models in Panel C are analogous to those in Panels A and B, but are limited to those with exactly a college or high school degree and all individual level covariates are additionally interacted with a college graduate dummy. In these specifications, female weeks worked is both entered directly and interacted with a college graduate dummy, with the coefficient on the interaction reported above. Panel $D$ tabulates separate regressions of estimated state level log 90-10 earnings ratio of male full-time weekly earners on weeks worked per female state resident, state dummies, a year dummy, and a constant. All education values for years 1940-1970 are coded as highest grade completed. Following the recommendations of Jaeger (1997), we define high school graduates in 1990 as those with twelve years of completed schooling, a GED, or a high school diploma and we define high school graduates in 1970 as those with exactly 12 years of completed schooling and no additional uncompleted schooling. Data are drawn from Census PUMS one percent samples (1950 sample line subsample) for years 1940-1970 and 1990. 1980 data is drawn from Census 5 percent sample using a randomly drawn 20 percent subsample. Samples include those ages 14 - 64 in earnings year, not living in institutional group quarters, residing in mainland U.S. state excluding Nevada and the District of Columbia with non-farm paid employment in survey reference week (excluding self-employed) and positive earnings in previous calendar year who earned between $\$ 0.50$ and $\$ 250$ an hour in 1990 dollars during the previous year (deflated by CPI All Urban Consumers series CUUR0000SA0) and worked at least 35 hours in the survey week and 40 weeks in the previous year. Top coded earnings values are imputed as 1.5 times the censored value. 
Table 3. Determinant of State Level WWII Mobilization Rates

Dependent Variable: Mobilization Rate

\begin{tabular}{|c|c|c|c|c|c|c|c|c|c|c|c|c|c|c|}
\hline & $\begin{array}{l}\text { Mean } \\
(\mathrm{sd})\end{array}$ & (1) & (2) & (3) & (4) & (5) & (6) & (7) & (8) & (9) & $(10)$ & (11) & (12) & (13) \\
\hline Share Farm & $\begin{array}{c}0.15 \\
(0.11)\end{array}$ & $\begin{array}{l}-0.17 \\
(0.05)\end{array}$ & $\begin{array}{l}-0.16 \\
(0.04)\end{array}$ & $\begin{array}{l}-0.17 \\
(0.03)\end{array}$ & $\begin{array}{l}-0.17 \\
(0.04)\end{array}$ & $\begin{array}{l}-0.23 \\
(0.06)\end{array}$ & $\begin{array}{l}-0.26 \\
(0.04)\end{array}$ & $\begin{array}{l}-0.22 \\
(0.04)\end{array}$ & $\begin{array}{l}-0.17 \\
(0.05)\end{array}$ & $\begin{array}{l}-0.16 \\
(0.04)\end{array}$ & $\begin{array}{l}-0.17 \\
(0.05)\end{array}$ & $\begin{array}{l}-0.20 \\
(0.04)\end{array}$ & $\begin{array}{l}-0.23 \\
(0.04)\end{array}$ & $\begin{array}{l}-0.25 \\
(0.04)\end{array}$ \\
\hline $\begin{array}{l}\text { Share Non- } \\
\text { white }\end{array}$ & $\begin{array}{c}0.10 \\
(0.11)\end{array}$ & $\begin{array}{c}0.00 \\
(0.05)\end{array}$ & $\begin{array}{l}-0.07 \\
(0.04)\end{array}$ & & $\begin{array}{l}-0.03 \\
(0.06)\end{array}$ & $\begin{array}{l}-0.38 \\
(0.27)\end{array}$ & $\begin{array}{c}0.04 \\
(0.05)\end{array}$ & $\begin{array}{l}-0.03 \\
(0.05)\end{array}$ & $\begin{array}{l}-0.03 \\
(0.06)\end{array}$ & $\begin{array}{c}0.02 \\
(0.06)\end{array}$ & $\begin{array}{l}-0.03 \\
(0.06)\end{array}$ & $\begin{array}{l}-0.01 \\
(0.06)\end{array}$ & & $\begin{array}{c}0.02 \\
(0.05)\end{array}$ \\
\hline $\begin{array}{c}\text { Avg } \\
\text { Completed }\end{array}$ & $\begin{array}{c}8.89 \\
(0.71)\end{array}$ & $\begin{array}{c}0.02 \\
(0.01)\end{array}$ & & $\begin{array}{c}0.01 \\
(0.01)\end{array}$ & $\begin{array}{c}0.01 \\
(0.01)\end{array}$ & $\begin{array}{c}0.01 \\
(0.01)\end{array}$ & $\begin{array}{c}0.03 \\
(0.01)\end{array}$ & $\begin{array}{c}0.01 \\
(0.01)\end{array}$ & $\begin{array}{c}0.01 \\
(0.01)\end{array}$ & $\begin{array}{c}0.01 \\
(0.01)\end{array}$ & $\begin{array}{c}0.01 \\
(0.01)\end{array}$ & $\begin{array}{c}0.01 \\
(0.01)\end{array}$ & & $\begin{array}{c}0.02 \\
(0.01)\end{array}$ \\
\hline $\begin{array}{c}\text { Share Ages } \\
13-24\end{array}$ & $\begin{array}{c}0.42 \\
(0.03)\end{array}$ & $\begin{array}{c}0.22 \\
(0.34)\end{array}$ & & & & & $\begin{array}{c}0.73 \\
(0.24)\end{array}$ & & & & & & $\begin{array}{l}-0.36 \\
(0.24)\end{array}$ & $\begin{array}{c}0.38 \\
(0.33)\end{array}$ \\
\hline $\begin{array}{c}\text { Share Ages } \\
25-34\end{array}$ & $\begin{array}{c}0.31 \\
(0.01)\end{array}$ & $\begin{array}{c}0.09 \\
(0.49)\end{array}$ & & & & & $\begin{array}{c}0.38 \\
(0.48)\end{array}$ & & & & & & $\begin{array}{l}-0.84 \\
(0.53)\end{array}$ & $\begin{array}{l}-0.03 \\
(0.54)\end{array}$ \\
\hline $\begin{array}{l}\text { Share } \\
\text { German }\end{array}$ & $\begin{array}{c}0.007 \\
(0.006)\end{array}$ & $\begin{array}{l}-3.15 \\
(0.90)\end{array}$ & & & & & & $\begin{array}{l}-1.88 \\
(0.55)\end{array}$ & & & & & $\begin{array}{l}-2.19 \\
(0.74)\end{array}$ & $\begin{array}{l}-1.16 \\
(0.76)\end{array}$ \\
\hline $\begin{array}{l}\text { Share Italian } \\
\text { or Japanese }\end{array}$ & $\begin{array}{c}0.010 \\
(0.012)\end{array}$ & $\begin{array}{c}1.67 \\
(0.52)\end{array}$ & & & & & & & $\begin{array}{c}0.00 \\
(0.42)\end{array}$ & & & & & \\
\hline $\begin{array}{l}\text { Share } \\
\text { Married }\end{array}$ & $\begin{array}{c}0.50 \\
(0.03)\end{array}$ & $\begin{array}{l}-0.09 \\
(0.18)\end{array}$ & & & & & & & & $\begin{array}{l}-0.22 \\
(0.13)\end{array}$ & & & & \\
\hline $\begin{array}{l}\text { Share } \\
\text { Fathers }\end{array}$ & $\begin{array}{c}0.47 \\
(0.03)\end{array}$ & $\begin{array}{c}0.07 \\
(0.13)\end{array}$ & & & & & & & & & $\begin{array}{c}0.00 \\
(0.12)\end{array}$ & & & \\
\hline $\begin{array}{l}\text { Draft Boards/ } \\
\text { Pop (1000/s) }\end{array}$ & $\begin{array}{c}0.19 \\
(0.05)\end{array}$ & $\begin{array}{c}0.06 \\
(0.07)\end{array}$ & & & & & & & & & & $\begin{array}{c}0.13 \\
(0.09)\end{array}$ & & \\
\hline Intercept & & $\begin{array}{c}0.20 \\
(0.34)\end{array}$ & $\begin{array}{c}0.51 \\
(0.01)\end{array}$ & $\begin{array}{c}0.40 \\
(0.05)\end{array}$ & $\begin{array}{c}0.42 \\
(0.08)\end{array}$ & $\begin{array}{c}0.46 \\
(0.12)\end{array}$ & $\begin{array}{l}-0.19 \\
(0.27)\end{array}$ & $\begin{array}{c}0.42 \\
(0.07)\end{array}$ & $\begin{array}{c}0.42 \\
(0.08)\end{array}$ & $\begin{array}{c}0.49 \\
(0.08)\end{array}$ & $\begin{array}{c}0.42 \\
(0.09)\end{array}$ & $\begin{array}{c}0.42 \\
(0.07)\end{array}$ & $\begin{array}{c}0.94 \\
(0.25)\end{array}$ & $\begin{array}{c}0.15 \\
(0.34)\end{array}$ \\
\hline $\mathrm{R}^{2}$ & & 0.78 & 0.57 & 0.58 & 0.58 & 0.39 & 0.68 & 0.67 & 0.58 & 0.61 & 0.58 & 0.60 & 0.62 & 0.70 \\
\hline $\begin{array}{l}\text { Southern } \\
\text { States }\end{array}$ & & Yes & Yes & Yes & Yes & No & Yes & Yes & Yes & Yes & Yes & Yes & Yes & Yes \\
\hline
\end{tabular}

Standard errors are in parenthesis for regression models. Standard deviations are in parentheses for column of means. Columns 1 - 13 contain regression estimates of state WWII mobilization rates (mean 0.475 , standard deviation 0.032 ) on listed variables. Sample includes observations for 47 U.S. states excluding Hawaii, Alaska, Nevada, and the District of Columbia. Regressions are weighted by male population ages 13 - 44 in each state from the 1940 Census PUMS. State mobilization rate is the number of males who served in WWII divided by the number registered males ages 18-44 during 1940 to 1945 from Selective Service (1956) monographs. The Percent Farm, Non-white, Married, and Average Education variables are state averages for these variables for males ages 13 - 44 calculated from the 1940 Census PUMS. Percent German, Italian, and Japanese are the fraction of male state residents ages 13-44 born in these countries. Percent Fathers is the fraction of women ages 14 - 44 with any children in 1940 (a proxy for paternity). Draft Boards per Population is the number of state local draft boards divided by the number of men registered in each state (in thousands) ages 18 - 44 during 1940 to 1945. Southern states excluded from column 5 include VA, AL, AR, FL, GA, LA, MS, NC, SC, TX, KY, MD, OK, TN, WV. 
Table 4. Impact of World War II Mobilization Rates on Female Labor Supply 1940 - 1950 Dependent Variable: Annual Weeks Worked

\begin{tabular}{|c|c|c|c|c|c|c|c|c|c|c|}
\hline & \multicolumn{5}{|c|}{ A. All Females } & \multicolumn{5}{|c|}{ B. White Females } \\
\hline & $(1)$ & $(2)$ & (3) & $(4)$ & (5) & (1) & $(2)$ & (3) & $(4)$ & (5) \\
\hline Mobilization Rate x 1950 & $\begin{array}{l}13.89 \\
(1.78)\end{array}$ & $\begin{array}{r}9.59 \\
(2.38)\end{array}$ & $\begin{array}{r}9.06 \\
(2.35)\end{array}$ & $\begin{array}{l}10.22 \\
(2.61)\end{array}$ & $\begin{array}{r}8.28 \\
(2.39)\end{array}$ & $\begin{array}{l}11.17 \\
(1.89)\end{array}$ & $\begin{array}{l}10.42 \\
(2.02)\end{array}$ & $\begin{array}{r}9.85 \\
(2.05)\end{array}$ & $\begin{array}{l}10.64 \\
(2.65)\end{array}$ & $\begin{array}{r}8.51 \\
(2.37)\end{array}$ \\
\hline $\begin{array}{l}1940 \text { Male Fraction } \\
\text { Farmers x } 1950\end{array}$ & & & & $\begin{array}{r}2.04 \\
(1.13)\end{array}$ & $\begin{array}{r}1.45 \\
(1.13)\end{array}$ & & & & $\begin{array}{r}1.74 \\
(1.08)\end{array}$ & $\begin{array}{r}1.04 \\
(1.05)\end{array}$ \\
\hline $\begin{array}{l}1940 \text { Male Fraction Non- } \\
\text { white x } 1950\end{array}$ & & & & $\begin{array}{r}-2.04 \\
(1.24)\end{array}$ & $\begin{array}{r}0.70 \\
(1.86)\end{array}$ & & & & $\begin{array}{r}-1.96 \\
(1.15)\end{array}$ & $\begin{array}{r}-0.72 \\
(1.37)\end{array}$ \\
\hline $\begin{array}{c}1940 \text { Male Average Years } \\
\text { of Education x } 1950\end{array}$ & & & & & $\begin{array}{r}0.51 \\
(0.18)\end{array}$ & & & & & $\begin{array}{r}0.52 \\
(0.16)\end{array}$ \\
\hline $\begin{array}{c}\mathrm{R}^{2} \\
\mathrm{n}\end{array}$ & 0.01 & 0.17 & $\begin{array}{c}0.17 \\
585,745\end{array}$ & 0.17 & 0.17 & 0.01 & 0.18 & $\begin{array}{c}0.18 \\
530,026\end{array}$ & 0.18 & 0.18 \\
\hline Age \& Marital Status & No & Yes & Yes & Yes & Yes & No & Yes & Yes & Yes & Yes \\
\hline State of Birth & No & No & Yes & Yes & Yes & No & No & Yes & Yes & Yes \\
\hline \multicolumn{11}{|c|}{$\begin{array}{l}\text { Standard errors in parenthesis account for clustering on state of residence and year of observation. Each } \\
\text { column is from a separate pooled } 1940 \text { and } 1950 \text { microdata regression of weeks worked by female state of } \\
\text { residence on WWII state mobilization rate interacted with a } 1950 \text { dummy, state of residence dummies, a non- } \\
\text { white dummy (where relevant), a year main effect, and a constant. Specifications in columns } 2-5 \text { also include } \\
\text { dummies for marital status and years of age. Specifications in columns } 3-5 \text { contain state/country of birth } \\
\text { dummies. All individual demographic variables, aside from state of residence/birth, are also interacted with a } \\
1950 \text { dummy for columns 2-5. As indicated, models also control for state fraction farmers, non-white, and } \\
\text { average years of completed schooling among males ages } 13-44 \text { in } 1940 \text { in women's state of residence (each } \\
\text { interacted with a } 1950 \text { dummy). Data are from Census PUMS one percent samples for } 1940 \text { and } 1950 \text { (sample } \\
\text { line sub-sample) and include females ages } 14-64 \text {, not living in institutional group quarters, not in farm } \\
\text { employment, and residing in mainland U.S. states excluding Nevada and District of Columbia. State } \\
\text { mobilization rate is assigned by female state of residence. }\end{array}$} \\
\hline
\end{tabular}




\section{Table 5. Impact of World War II Mobilization Rates on Female Labor Supply 1940 - 1950 \\ Controlling for the Fraction Males in Occupations in 1940 Dependent Variable: Female Annual Weeks Worked by State}

\begin{tabular}{|c|c|c|c|c|c|c|c|c|c|c|}
\hline & $(1)$ & $(2)$ & $(3)$ & (4) & (5) & $(6)$ & (7) & (8) & $(9)$ & (10) \\
\hline $\begin{array}{l}1940 \text { Occupation } \\
\text { Share Controlled }\end{array}$ & $\begin{array}{l}\text { Prof/ } \\
\text { Tech }\end{array}$ & Mngrs & Clerks & Sales & Craft & $\begin{array}{l}\text { Oper- } \\
\text { atives }\end{array}$ & $\begin{array}{l}\text { Svcs/ } \\
\text { Private }\end{array}$ & Svcs & $\begin{array}{l}\text { Labor- } \\
\text { ers }\end{array}$ & $\begin{array}{l}\text { Defense } \\
\text { Indust. }\end{array}$ \\
\hline & \multicolumn{10}{|c|}{ A. Main specification } \\
\hline $\begin{array}{c}\text { Mobilization Rate } x \\
1950\end{array}$ & $\begin{array}{r}8.44 \\
(2.35)\end{array}$ & $\begin{array}{r}8.24 \\
(2.12)\end{array}$ & $\begin{array}{l}10.90 \\
(2.31)\end{array}$ & $\begin{array}{r}9.90 \\
(2.43)\end{array}$ & $\begin{array}{r}8.77 \\
(2.50)\end{array}$ & $\begin{array}{l}10.61 \\
(2.52)\end{array}$ & $\begin{array}{r}7.88 \\
(2.41)\end{array}$ & $\begin{array}{l}10.87 \\
(2.46)\end{array}$ & $\begin{array}{r}9.06 \\
(2.33)\end{array}$ & $\begin{array}{r}8.86 \\
(2.29)\end{array}$ \\
\hline $\begin{array}{c}1940 \text { Male Occ. } \\
\text { Share x } 1950\end{array}$ & $\begin{array}{r}2.86 \\
(7.23)\end{array}$ & $\begin{array}{r}5.82 \\
(6.92)\end{array}$ & $\begin{array}{r}-5.57 \\
(3.86)\end{array}$ & $\begin{array}{r}-3.56 \\
(6.42)\end{array}$ & $\begin{array}{r}0.60 \\
(3.89)\end{array}$ & $\begin{array}{r}-2.45 \\
(2.09)\end{array}$ & $\begin{array}{l}-51.81 \\
(61.05)\end{array}$ & $\begin{array}{r}-12.66 \\
(5.71)\end{array}$ & $\begin{array}{r}-5.27 \\
(4.12)\end{array}$ & $\begin{array}{r}0.45 \\
(1.24)\end{array}$ \\
\hline \multirow[t]{2}{*}{$\mathrm{R}^{2}$} & 0.17 & 0.17 & 0.17 & 0.17 & 0.17 & 0.17 & 0.17 & 0.17 & 0.17 & 0.17 \\
\hline & \multicolumn{10}{|c|}{ B. Controlling for 1940 Share Farm and Non-White, and Average Years of Education } \\
\hline $\begin{array}{c}\text { Mobilization Rate x } \\
1950\end{array}$ & $\begin{array}{r}8.11 \\
(2.44)\end{array}$ & $\begin{array}{r}7.79 \\
(2.59)\end{array}$ & $\begin{array}{r}5.97 \\
(2.47)\end{array}$ & $\begin{array}{r}7.78 \\
(2.32)\end{array}$ & $\begin{array}{r}8.48 \\
(2.63)\end{array}$ & $\begin{array}{r}8.45 \\
(2.30)\end{array}$ & $\begin{array}{r}8.30 \\
(2.35)\end{array}$ & $\begin{array}{r}7.11 \\
(2.46)\end{array}$ & $\begin{array}{r}8.42 \\
(2.62)\end{array}$ & $\begin{array}{l}10.56 \\
(2.48)\end{array}$ \\
\hline $\begin{array}{c}1940 \text { Male Occ. } \\
\text { Share x } 1950\end{array}$ & $\begin{array}{r}-2.87 \\
(8.68)\end{array}$ & $\begin{array}{l}-7.25 \\
(8.49)\end{array}$ & $\begin{array}{r}-10.26 \\
(5.20)\end{array}$ & $\begin{array}{r}-15.74 \\
(6.80)\end{array}$ & $\begin{array}{r}1.14 \\
(8.02)\end{array}$ & $\begin{array}{r}3.88 \\
(2.60)\end{array}$ & $\begin{array}{l}-19.08 \\
(73.70)\end{array}$ & $\begin{array}{r}-13.84 \\
(7.52)\end{array}$ & $\begin{array}{r}-0.57 \\
(3.69)\end{array}$ & $\begin{array}{r}2.29 \\
(1.19)\end{array}$ \\
\hline $\mathrm{R}^{2}$ & 0.17 & 0.17 & 0.17 & 0.17 & 0.17 & 0.17 & 0.17 & 0.17 & 0.17 & 0.17 \\
\hline $\mathrm{n}$ & \multicolumn{10}{|c|}{585,745} \\
\hline
\end{tabular}

Standard errors in parenthesis account for clustering on state of residence and year of observation. Each column is from a separate pooled 1940 and 1950 microdata regression of weeks worked by female state of residence on WWII state mobilization rate interacted with a 1950 dummy, the fraction of males in the listed occupational (industry) category in 1940 interacted with a 1950 dummy, a year main effect, a constant, and dummies for: non-white (where relevant), age, marital status, state of residence, and state/country of birth. All individual demographic variables, aside from state of residence/birth, are also interacted with a 1950 dummy. Models in panel B also control for state fraction farmers, non-white, and average years of completed schooling among males ages 13 - 44 in 1940 in women's state of residence (each interacted with a 1950 dummy.) Data are from Census PUMS one percent samples for 1940 and 1950 (sample line subsample) and include females ages 14 - 64 not living in institutional group quarters, not in farm employment, and residing in mainland U.S. states excluding Nevada and District of Columbia. State mobilization rate is assigned by female state of residence. Occupation and Industry codes correspond to major (1-digit) occupational and industry categories. The defense industries correspond to IPUMS 1950 industry codes 326 - 388. 


\section{Table 6: Instrumental Variables Estimates of the Impact of World War II Mobilization Rates on Female Labor Supply 1940 - 1950 \\ Dependent Variable: Annual Weeks Worked}

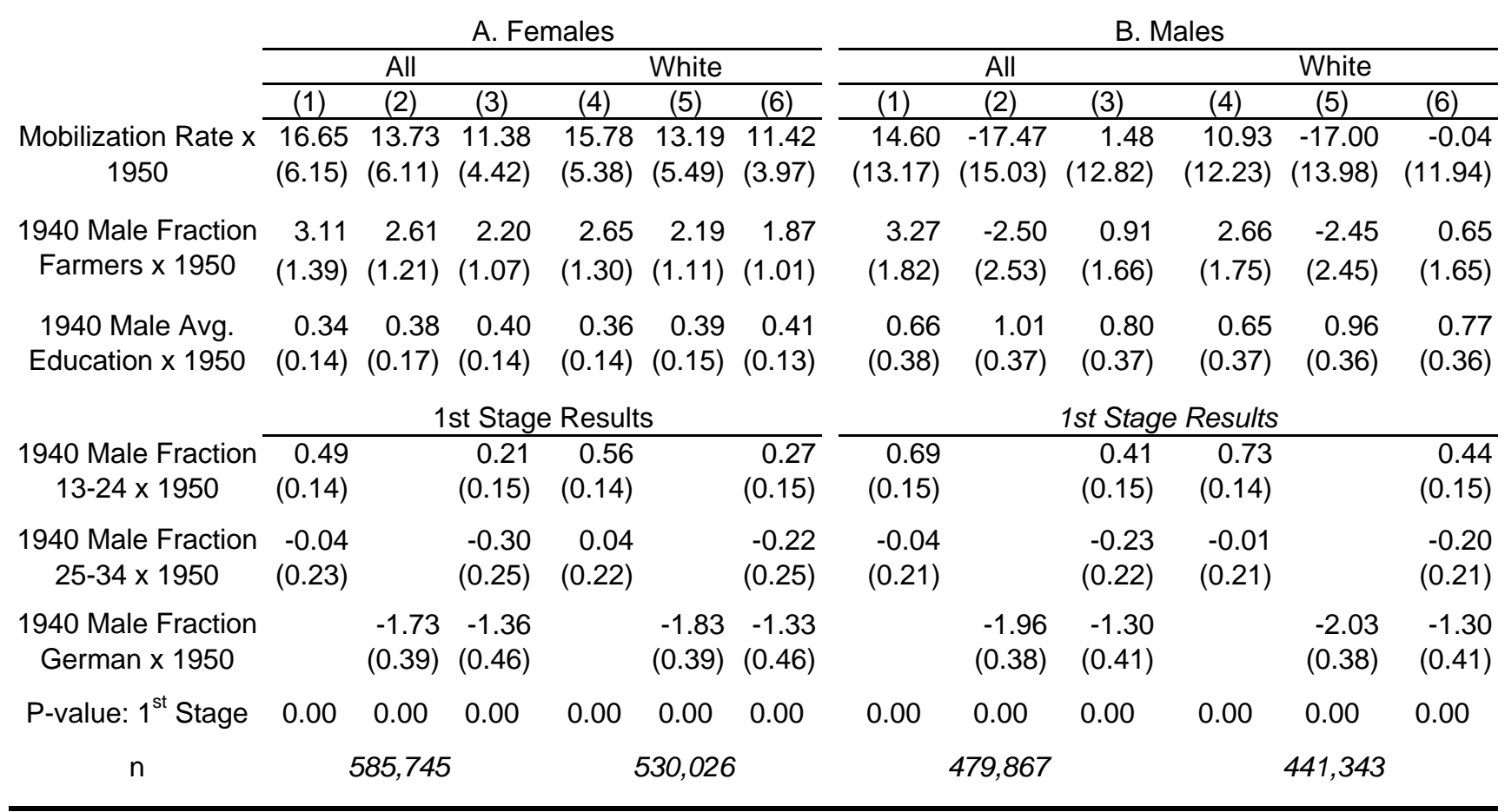

Standard errors in parenthesis account for clustering on state of residence and year of observation. Each column is from a separate pooled 1940 and 1950 microdata 2SLS regression of weeks worked by female state of residence on instrumented WWII state mobilization rate interacted with a 1950 dummy, a year main effect, a constant, and dummies for: non-white (where relevant), age, marital status, state of residence, and state/country of birth. All individual demographic variables, aside from state of residence/birth, are also interacted with a 1950 dummy. Instruments used in the first stage of these models are the fraction of males ages 13-44 in 1940 who are of German birth or who are in the listed age categories (each interacted with a 1950 dummy). Models also control for state fraction farmers and average years of completed schooling among males ages 13 - 44 in 1940 in women's state of residence (interacted with a 1950 dummy). Data are from Census PUMS one percent samples for 1940 and 1950 (sample line sub-sample) and include those ages 14 - 64, not living in institutional group quarters, not in farm employment, and residing in mainland U.S. states excluding Nevada and District of Columbia. State mobilization rate is assigned by state of residence. 


\section{Table 7. Impact of World War II Mobilization Rates on Female Labor Supply $1940-1950$ and $1950-1960$ \\ Dependent Variable: Female Weeks Worked}

\begin{tabular}{|c|c|c|c|c|c|c|c|c|}
\hline & \multicolumn{8}{|c|}{ Coefficient on Mobilization Rate Variable x 1950} \\
\hline & \multicolumn{8}{|c|}{ A. $1940-1950$} \\
\hline & \multicolumn{4}{|c|}{ All } & \multicolumn{4}{|c|}{ White } \\
\hline & $(1)$ & (2) & (3) & $(4)$ & $(5)$ & $(6)$ & $(7)$ & (8) \\
\hline Weeks Worked & $\begin{array}{r}9.06 \\
(2.35)\end{array}$ & $\begin{array}{r}8.28 \\
(2.39)\end{array}$ & $\begin{array}{l}12.21 \\
(2.98)\end{array}$ & $\begin{array}{r}6.54 \\
(2.31)\end{array}$ & $\begin{array}{r}9.85 \\
(2.05)\end{array}$ & $\begin{array}{r}8.51 \\
(2.37)\end{array}$ & $\begin{array}{l}11.28 \\
(2.97)\end{array}$ & $\begin{array}{r}6.34 \\
(2.40)\end{array}$ \\
\hline $\mathrm{R}^{2}$ & 0.17 & 0.17 & 0.17 & 0.19 & 0.18 & 0.18 & 0.18 & 0.20 \\
\hline $\begin{array}{l}\text { Any Weeks } \\
\text { Worked }\end{array}$ & $\begin{array}{r}0.019 \\
(0.076)\end{array}$ & $\begin{array}{r}0.184 \\
(0.072)\end{array}$ & $\begin{array}{r}0.282 \\
(0.079)\end{array}$ & $\begin{array}{r}0.148 \\
(0.080)\end{array}$ & $\begin{array}{r}0.063 \\
(0.069)\end{array}$ & $\begin{array}{r}0.174 \\
(0.071)\end{array}$ & $\begin{array}{r}0.253 \\
(0.080)\end{array}$ & $\begin{array}{r}0.130 \\
(0.081)\end{array}$ \\
\hline $\mathrm{R}^{2}$ & 0.17 & 0.17 & 0.17 & 0.19 & 0.18 & 0.18 & 0.18 & 0.20 \\
\hline \multirow[t]{5}{*}{$\mathrm{n}$} & 585,745 & 585,745 & 585,745 & 410,794 & 530,026 & 530,026 & 530,026 & 393,820 \\
\hline & \multicolumn{8}{|c|}{ Coefficient on Mobilization Rate Variable x 1960} \\
\hline & \multicolumn{8}{|c|}{ B. $1950-1960$} \\
\hline & \multicolumn{4}{|c|}{ All } & \multicolumn{4}{|c|}{ White } \\
\hline & $(1)$ & $(2)$ & (3) & (4) & (5) & (6) & (7) & (8) \\
\hline Weeks Worked & $\begin{array}{r}-3.85 \\
(1.95)\end{array}$ & $\begin{array}{r}2.70 \\
(2.15)\end{array}$ & $\begin{array}{r}0.09 \\
(2.43)\end{array}$ & $\begin{array}{r}3.66 \\
(2.11)\end{array}$ & $\begin{array}{r}-7.25 \\
(1.81)\end{array}$ & $\begin{array}{r}2.15 \\
(1.95)\end{array}$ & $\begin{array}{r}0.39 \\
(2.23)\end{array}$ & $\begin{array}{r}3.56 \\
(1.86)\end{array}$ \\
\hline $\mathrm{R}^{2}$ & 0.14 & 0.14 & 0.14 & 0.16 & 0.15 & 0.15 & 0.15 & 0.17 \\
\hline $\begin{array}{l}\text { Any Weeks } \\
\text { Worked }\end{array}$ & $\begin{array}{r}0.044 \\
(0.054)\end{array}$ & $\begin{array}{r}-0.009 \\
(0.069)\end{array}$ & $\begin{array}{r}-0.017 \\
(0.071)\end{array}$ & $\begin{array}{r}0.032 \\
(0.073)\end{array}$ & $\begin{array}{r}-0.057 \\
(0.049)\end{array}$ & $\begin{array}{r}-0.006 \\
(0.067)\end{array}$ & $\begin{array}{r}0.002 \\
(0.064)\end{array}$ & $\begin{array}{r}0.035 \\
(0.069)\end{array}$ \\
\hline $\mathrm{R}^{2}$ & 0.13 & 0.13 & 0.13 & 0.14 & 0.14 & 0.14 & 0.14 & 0.15 \\
\hline $\mathrm{n}$ & 683,976 & 683,976 & 683,976 & 480,545 & 615,590 & 615,590 & 615,590 & 449,275 \\
\hline $\begin{array}{l}\text { Fraction Farm / } \\
\text { Non-white/ Avg Ed }\end{array}$ & No & Yes & Yes & Yes & No & Yes & Yes & Yes \\
\hline Region x 1950 & No & No & Yes & No & No & No & Yes & No \\
\hline Excluding South & No & No & No & Yes & No & No & No & Yes \\
\hline
\end{tabular}

Standard errors in parenthesis account for clustering on state of residence and year of observation. Each column is from a separate pooled 1940 - 1950 or 1950 - 1960 microdata regression of individual weeks worked on WWII state mobilization rate interacted with a 1950 or 1960 dummy (in Panels A and B respectively), a year main effect, a constant, and dummies for: non-white (where relevant), marital status, age, state of residence, and state/country of birth. All individual demographic variables, aside from state of residence/birth, are also interacted with a 1950 or 1960 dummy. As indicated, models also control for state fraction farmers, non-white, and average education among males ages 13 - 44 in 1940 in women's state of residence (each interacted with a 1950 dummy.) State mobilization rate is assigned by female state of residence. Data are from Census PUMS one percent samples for 1940, 1950 (sample line sub-sample) and 1960, and include females ages 14 - 64, not living in institutional group quarters, not in farm employment, and residing in mainland U.S. state excluding Nevada and District of Columbia. Weeks worked for 1960 is calculated using the midpoint of the intervalled weeks worked. Any weeks worked is defined as weeks worked greater than zero. Region $\times 1950$ dummies refer to 4 main Census geographic regions. Southern states excluded from columns 4 and 8 are VA, AL, AR, FL, MS, NC, SC, $\mathrm{TX}, \mathrm{KY}, \mathrm{MD}, \mathrm{OK}, \mathrm{TN}$, and WV. 
Table 8. Impact of World War II Mobilization Rates on Male Labor Supply 1940 - 1950 Dependent Variable: Annual Weeks Worked

\begin{tabular}{|c|c|c|c|c|c|c|c|c|c|}
\hline & \multicolumn{9}{|c|}{ A. All Males } \\
\hline & \multicolumn{5}{|c|}{ All } & \multicolumn{2}{|c|}{ Non-Vets } & \multicolumn{2}{|c|}{ Vets } \\
\hline & (1) & (2) & (3) & (4) & (5) & (6) & (7) & $(8)$ & (9) \\
\hline Mobilization Rate x 1950 & $\begin{array}{r}4.09 \\
(5.96)\end{array}$ & $\begin{array}{r}5.33 \\
(5.63)\end{array}$ & $\begin{array}{r}5.09 \\
(5.69)\end{array}$ & $\begin{array}{r}-5.50 \\
(7.56)\end{array}$ & $\begin{array}{r}-5.41 \\
(8.01)\end{array}$ & $\begin{array}{r}7.79 \\
(6.51)\end{array}$ & $\begin{array}{r}-2.82 \\
(9.27)\end{array}$ & $\begin{array}{r}0.53 \\
(5.40)\end{array}$ & $\begin{array}{r}-10.63 \\
(7.35)\end{array}$ \\
\hline $\begin{array}{l}1940 \text { Male Fraction } \\
\text { Farmers x } 1950\end{array}$ & & & & $\begin{array}{r}2.30 \\
(1.34)\end{array}$ & $\begin{array}{r}2.33 \\
(1.47)\end{array}$ & & $\begin{array}{r}2.50 \\
(1.88)\end{array}$ & & $\begin{array}{r}2.40 \\
(1.35)\end{array}$ \\
\hline $\begin{array}{c}1940 \text { Male Fraction Non- } \\
\text { white x } 1950\end{array}$ & & & & $\begin{array}{r}-9.15 \\
(1.24)\end{array}$ & $\begin{array}{r}-9.32 \\
(2.66)\end{array}$ & & $\begin{array}{r}-10.59 \\
(3.51)\end{array}$ & & $\begin{array}{r}-7.52 \\
(1.40)\end{array}$ \\
\hline $\begin{array}{c}1940 \text { Male Avg Years of } \\
\text { Schooling x } 1950\end{array}$ & & & & & $\begin{array}{l}-0.03 \\
(0.47)\end{array}$ & & $\begin{array}{l}-0.21 \\
(0.59)\end{array}$ & & $\begin{array}{r}0.29 \\
(0.27)\end{array}$ \\
\hline \multirow{5}{*}{$\begin{array}{c}\mathrm{R}^{2} \\
\mathrm{n}\end{array}$} & 0.02 & 0.35 & 0.35 & 0.35 & 0.36 & 0.36 & 0.36 & 0.34 & 0.34 \\
\hline & & & 479,867 & & & 442 & 606 & 397 & 7,338 \\
\hline & \multicolumn{9}{|c|}{ B. White Males } \\
\hline & \multicolumn{5}{|c|}{ All } & \multicolumn{2}{|c|}{ Non-Vets } & \multicolumn{2}{|c|}{ Vets } \\
\hline & (1) & $(2)$ & (3) & (4) & (5) & (6) & $(7)$ & (8) & (9) \\
\hline Mobilization Rate x 1950 & $\begin{array}{r}0.46 \\
(5.98)\end{array}$ & $\begin{array}{r}4.09 \\
(5.34)\end{array}$ & $\begin{array}{r}3.60 \\
(5.43)\end{array}$ & $\begin{array}{r}-6.56 \\
(7.12)\end{array}$ & $\begin{array}{r}-6.56 \\
(7.59)\end{array}$ & $\begin{array}{r}7.37 \\
(6.46)\end{array}$ & $\begin{array}{r}-4.15 \\
(9.02)\end{array}$ & $\begin{array}{r}-4.03 \\
(4.71)\end{array}$ & $\begin{array}{r}-10.84 \\
(6.64)\end{array}$ \\
\hline $\begin{array}{l}1940 \text { Male Fraction } \\
\text { Farmers x } 1950\end{array}$ & & & & $\begin{array}{r}1.97 \\
(1.27)\end{array}$ & $\begin{array}{r}1.97 \\
(1.41)\end{array}$ & & $\begin{array}{r}1.97 \\
(1.86)\end{array}$ & & $\begin{array}{r}2.74 \\
(1.39)\end{array}$ \\
\hline $\begin{array}{l}1940 \text { Male Fraction Non- } \\
\text { white } \times 1950\end{array}$ & & & & $\begin{array}{r}-9.11 \\
(1.21)\end{array}$ & $\begin{array}{r}-9.11 \\
(1.46)\end{array}$ & & $\begin{array}{r}-10.56 \\
(2.04)\end{array}$ & & $\begin{array}{r}-6.50 \\
(0.85)\end{array}$ \\
\hline $\begin{array}{c}1940 \text { Male Avg Years of } \\
\text { Schooling x } 1950\end{array}$ & & & & & $\begin{array}{r}0.00 \\
(0.44)\end{array}$ & & $\begin{array}{l}-0.19 \\
(0.57)\end{array}$ & & $\begin{array}{r}0.36 \\
(0.23)\end{array}$ \\
\hline $\begin{array}{c}\mathrm{R}^{2} \\
\mathrm{n}\end{array}$ & 0.02 & 0.36 & $\begin{array}{c}0.36 \\
441,343\end{array}$ & 0.36 & 0.36 & $\begin{array}{r}0.37 \\
406\end{array}$ & $\begin{array}{l}0.37 \\
591\end{array}$ & $\begin{array}{r}0.35 \\
366\end{array}$ & $\begin{array}{l}0.35 \\
, 737\end{array}$ \\
\hline Age \& Marital Status & No & Yes & Yes & Yes & Yes & Yes & Yes & Yes & Yes \\
\hline State of Birth & No & No & Yes & Yes & Yes & No & Yes & No & Yes \\
\hline
\end{tabular}

Standard errors in parenthesis account for clustering on state of residence and year of observation. Each column is from a separate pooled 1940 - 1950 microdata regression of individual weeks worked on WWII state mobilization rate interacted with a 1950 dummy, a year main effect, a constant, and dummies for nonwhite (where relevant) and state of residence. Specifications in columns 2 - 5 add dummies for married and age. Specifications in columns 3 - 5 add state/country of birth dummies. Columns 6 - 9 include all 1940 males and only WWII Veterans or Non-Veterans in 1950 as noted. All individual demographic variables, aside from state of residence/birth, are also interacted with a 1950 dummy for columns 2-9. As indicated, models also control for state fraction farmers, non-white, and average education among males ages 13 44 in 1940 in male's state of residence (each interacted with a 1950 dummy). State mobilization rate is assigned by male state of residence. 
Table 9. IV Specifications: Impact of Female Labor Supply on Female and Male Earnings 1940 - 1950 Dependent Variable: Log Weekly Earnings

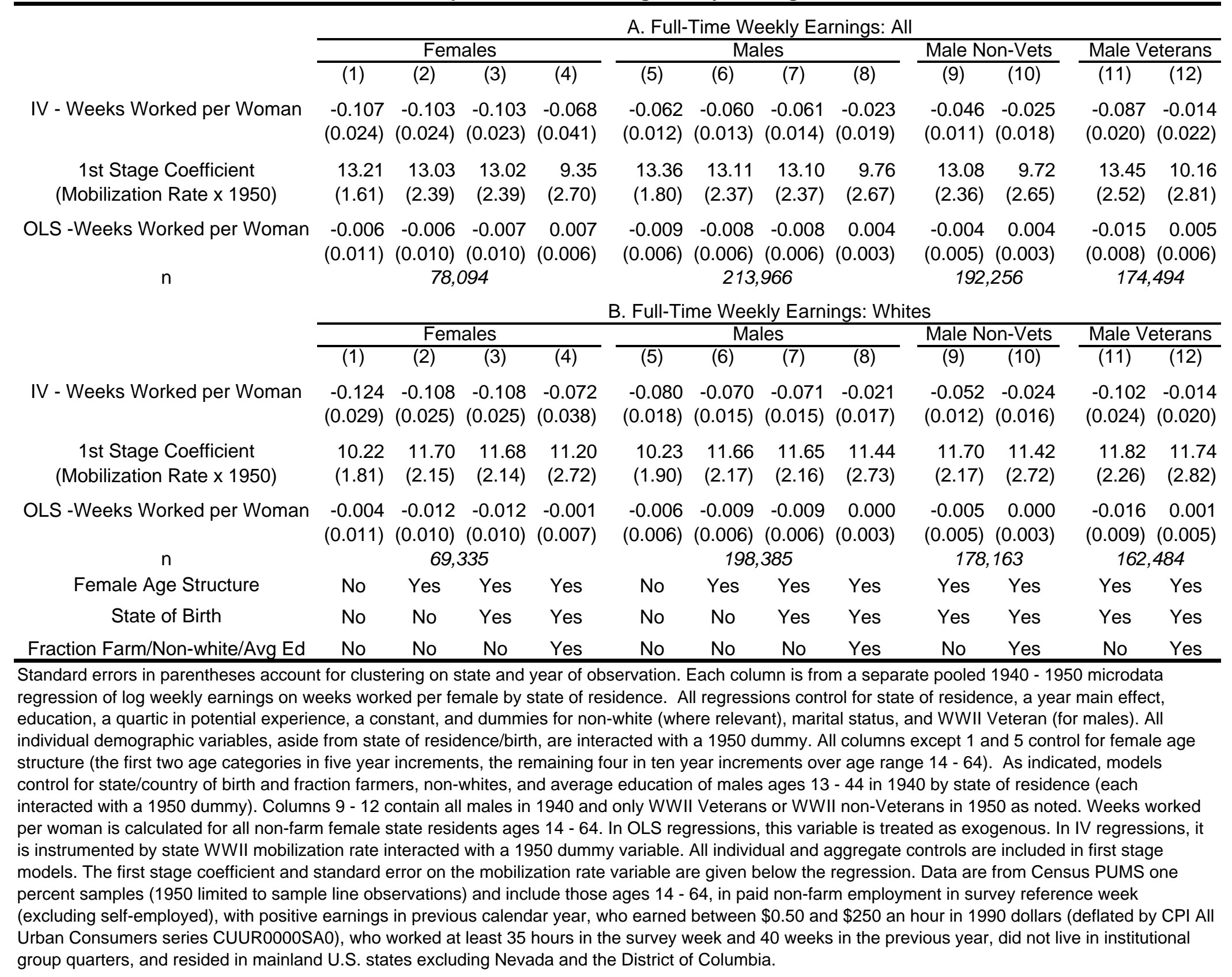


Table 10. Impact of Female Labor Supply on Female/Male Earnings Differential 1940 - 1950 Dependent Variable: Log Weekly Earnings

\begin{tabular}{|c|c|c|c|c|c|c|c|c|}
\hline & \multicolumn{8}{|c|}{$\begin{array}{l}\text { A. Full-Time Weekly Earnings: All } \\
\end{array}$} \\
\hline & \multicolumn{4}{|c|}{$\begin{array}{l}\text { Labor Supply Measured } \\
\text { in Weeks }\end{array}$} & \multicolumn{4}{|c|}{$\begin{array}{c}\text { Labor Supply Measured } \\
\text { in Efficiency Units }\end{array}$} \\
\hline & $(1)$ & $(2)$ & (3) & $(4)$ & $(5)$ & (6) & $(7)$ & $(8)$ \\
\hline $\ln \left(\mathrm{LS}_{\mathrm{Female}} / \mathrm{LS}_{\text {Male }}\right)$ & $\begin{array}{r}-0.390 \\
(0.075)\end{array}$ & $\begin{array}{r}-0.386 \\
(0.074)\end{array}$ & $\begin{array}{r}-0.391 \\
(0.076)\end{array}$ & $\begin{array}{r}-0.226 \\
(0.190)\end{array}$ & $\begin{array}{r}-0.471 \\
(0.098)\end{array}$ & $\begin{array}{r}-0.440 \\
(0.092)\end{array}$ & $\begin{array}{r}-0.446 \\
(0.095)\end{array}$ & $\begin{array}{r}-0.197 \\
(0.165)\end{array}$ \\
\hline $\begin{array}{c}\ln \left(\mathrm{LS}_{\text {Female }} / \mathrm{LS}_{\text {Male }}\right) \\
x \text { Female }\end{array}$ & $\begin{array}{l}-0.328 \\
(0.115)\end{array}$ & $\begin{array}{l}-0.278 \\
(0.105)\end{array}$ & $\begin{array}{r}-0.272 \\
(0.099)\end{array}$ & $\begin{array}{l}-0.354 \\
(0.182)\end{array}$ & $\begin{array}{l}-0.432 \\
(0.157)\end{array}$ & $\begin{array}{l}-0.332 \\
(0.126)\end{array}$ & $\begin{array}{l}-0.324 \\
(0.119)\end{array}$ & $\begin{array}{l}-0.309 \\
(0.161)\end{array}$ \\
\hline $\begin{array}{c}\text { 1st Stage Coefficient } \\
\text { (Mobilization Rate x 1950) }\end{array}$ & $\begin{array}{r}2.05 \\
(0.19)\end{array}$ & $\begin{array}{r}2.03 \\
(0.25)\end{array}$ & $\begin{array}{r}2.03 \\
(0.25)\end{array}$ & $\begin{array}{r}1.09 \\
(0.25)\end{array}$ & $\begin{array}{r}1.67 \\
(0.19)\end{array}$ & $\begin{array}{r}1.77 \\
(0.24)\end{array}$ & $\begin{array}{r}1.77 \\
(0.24)\end{array}$ & $\begin{array}{r}1.24 \\
(0.29)\end{array}$ \\
\hline Implied Female Demand $\sigma_{\mathrm{F}}$ & -1.39 & -1.51 & -1.51 & -1.73 & -1.11 & -1.30 & -1.30 & -1.98 \\
\hline Implied M/F Substition $\sigma_{\mathrm{M} / \mathrm{F}}$ & -3.05 & -3.60 & -3.68 & -2.83 & -2.32 & -3.02 & -3.08 & -3.24 \\
\hline \multirow[t]{4}{*}{$\mathrm{n}$} & \multicolumn{7}{|c|}{292,060} & 0.08 \\
\hline & \multicolumn{8}{|c|}{ B. Full-Time Weekly Earnings: White } \\
\hline & \multicolumn{4}{|c|}{$\begin{array}{l}\text { Labor Supply Measured } \\
\text { in Weeks } \\
\end{array}$} & \multicolumn{4}{|c|}{$\begin{array}{c}\text { Labor Supply Measured } \\
\text { in Efficiency Units }\end{array}$} \\
\hline & (1) & $(2)$ & (3) & (4) & $(5)$ & $(6)$ & $(7)$ & $(8)$ \\
\hline $\ln \left(\mathrm{LS}_{\mathrm{Female}} / \mathrm{LS}_{\mathrm{Male}}\right)$ & $\begin{array}{r}-0.513 \\
(0.107)\end{array}$ & $\begin{array}{l}-0.463 \\
(0.089)\end{array}$ & $\begin{array}{r}-0.469 \\
(0.092)\end{array}$ & $\begin{array}{r}-0.254 \\
(0.200)\end{array}$ & $\begin{array}{r}-0.527 \\
(0.113)\end{array}$ & $\begin{array}{r}-0.473 \\
(0.096)\end{array}$ & $\begin{array}{r}-0.480 \\
(0.099)\end{array}$ & $\begin{array}{r}-0.237 \\
(0.185)\end{array}$ \\
\hline $\begin{array}{c}\ln \left(\mathrm{LS}_{\text {Female }} / \mathrm{LS}_{\text {Male }}\right) \\
x \text { Female }\end{array}$ & $\begin{array}{l}-0.315 \\
(0.126)\end{array}$ & $\begin{array}{l}-0.264 \\
(0.117)\end{array}$ & $\begin{array}{l}-0.254 \\
(0.116)\end{array}$ & $\begin{array}{l}-0.421 \\
(0.191)\end{array}$ & $\begin{array}{l}-0.331 \\
(0.139)\end{array}$ & $\begin{array}{l}-0.277 \\
(0.124)\end{array}$ & $\begin{array}{l}-0.266 \\
(0.122)\end{array}$ & $\begin{array}{l}-0.380 \\
(0.170)\end{array}$ \\
\hline $\begin{array}{c}\text { 1st Stage Coefficient } \\
\text { (Mobilization Rate x 1950) }\end{array}$ & $\begin{array}{r}1.56 \\
(0.19)\end{array}$ & $\begin{array}{r}1.75 \\
(0.22)\end{array}$ & $\begin{array}{r}1.75 \\
(0.22)\end{array}$ & $\begin{array}{r}1.14 \\
(0.30)\end{array}$ & $\begin{array}{r}1.51 \\
(0.20)\end{array}$ & $\begin{array}{r}1.70 \\
(0.24)\end{array}$ & $\begin{array}{r}1.70 \\
(0.24)\end{array}$ & $\begin{array}{r}1.22 \\
(0.34)\end{array}$ \\
\hline Implied Female Demand $\sigma_{\mathrm{F}}$ & -1.21 & -1.38 & -1.38 & -1.48 & -1.17 & -1.33 & -1.34 & -1.62 \\
\hline Implied M/F Substition $\sigma_{\mathrm{M} / \mathrm{F}}$ & -3.18 & -3.78 & -3.94 & -2.37 & -3.02 & -3.61 & -3.76 & -2.63 \\
\hline $\begin{array}{c}p \text {-value of } H_{0}:\left(\sigma_{F}\right)^{-1}=0 \\
n\end{array}$ & 0.00 & 0.00 & 0.00 & $\begin{array}{r}0.06 \\
267\end{array}$ & 0.00 & 0.00 & 0.00 & 0.06 \\
\hline Female Age Structure & No & Yes & Yes & Yes & No & Yes & Yes & Yes \\
\hline State of Birth & No & No & Yes & Yes & No & No & Yes & Yes \\
\hline Farm/Non-white/Avg Ed & No & No & No & Yes & No & No & No & Yes \\
\hline
\end{tabular}

Standard errors in parentheses account for clustering on state and year of observation. Each column is from a separate pooled 1940 - 1950 microdata regression of log weekly male and female earnings on the log ratio of female to male nonfarm labor supply measured in weeks (columns 1-4) or efficiency units (columns 5 - 8). All models include controls for veteran status, nonwhite, marital status, education, a quartic in potential experience, (each interacted with a female dummy and a 1950 dummy), state of residence, and a year main effect. As indicated, models control for state female age structure and state/country of birth, and state fraction farmers, non-whites, and average education among males ages 13 44 in 1940 (each interacted with a 1950 dummy.) All variables are interacted with a female dummy. Log of (female/male) labor supply measure is calculated for all non-farm state residents ages $14-64$. This measure and its interaction with a female dummy are instrumented by state WWII mobilization rate and its interaction with a female dummy. The first stage coefficient on the mobilization rate main effect is tabulated below each regression. All individual and aggregate controls are included in first stage models. See text for details of the efficiency unit measure used in columns 5 - 8. 
Table 11. Impact of Female Labor Supply on Male Educational Earnings Differentials 1940 - 1950 Dependent Variable: Log Weekly Earnings

\begin{tabular}{|c|c|c|c|c|c|c|c|c|c|c|}
\hline & & Male C & ollege / & High Sch & nool Gras & ate Log W & leekly Ea & arnings $D$ & Differentic & \\
\hline & & & All Males & & & & & hite Mals & & \\
\hline & (1) & (2) & (3) & (4) & (5) & (1) & $(2)$ & $(3)$ & (4) & (5) \\
\hline $\ln \left(\mathrm{LS}_{\text {Female }} / \mathrm{LS}_{\text {Male }}\right)$ & -0.382 & -0.424 & -0.267 & -0.401 & -0.265 & -0.471 & -0.466 & -0.269 & -0.428 & -0.270 \\
\hline & $(0.096)$ & $(0.101)$ & $(0.225)$ & $(0.115)$ & $(0.229)$ & $(0.126)$ & $(0.118)$ & $(0.228)$ & $(0.141)$ & $(0.228)$ \\
\hline $\ln \left(\mathrm{LS}_{\text {Female/Male }}\right) \times$ College & 0.139 & 0.154 & 0.162 & 0.189 & 0.175 & 0.206 & 0.261 & 0.233 & 0.283 & 0.231 \\
\hline $\begin{array}{c}\ln \left(\text { LS }_{\text {College-Male/ }}\right. \\
\left.\text { LS }_{\text {HS }}\right) \times \text { College }\end{array}$ & & & & $\begin{array}{r}-0.098 \\
(0.094)\end{array}$ & $\begin{array}{r}-0.069 \\
(0086)\end{array}$ & & & & -0.042 & $\begin{aligned}-0.004 \\
080)\end{aligned}$ \\
\hline & & & 1 & & & & & & & \\
\hline (Mobilization Rate x 1950) & $\begin{array}{r}2.06 \\
(0.21)\end{array}$ & $\begin{array}{r}2.04 \\
(0.27)\end{array}$ & $(0.25)$ & $\begin{array}{r}1.94 \\
(0.28)\end{array}$ & $(0.25)$ & $\begin{array}{l}1.02 \\
(0.20)\end{array}$ & $(0.23)$ & $(0.30)$ & $\begin{array}{l}1.64 \\
(0.24)\end{array}$ & $(0.30)$ \\
\hline Implied relative & 0.64 & 0.64 & 0.39 & 0.53 & 0.34 & 0.56 & 0.44 & 0.14 & 0.34 & 0.15 \\
\hline $\mathrm{n}$ & & & 60,445 & & & & & 58,885 & & \\
\hline & & B. High & School & Graduate & 3th $\mathrm{Gr}$ & Log Wee & kly Earn & ings Diff & ferential & \\
\hline & & & All Males & & & & & hite Male & & \\
\hline & (1) & (2) & (3) & (4) & (5) & (1) & $(2)$ & (3) & $(4)$ & (5) \\
\hline $\ln \left(\mathrm{LS}_{\mathrm{Female}} \mathrm{LS}_{\mathrm{Male}}\right)$ & -0.170 & -0.205 & -0.074 & -0.162 & -0.098 & -0.192 & -0.220 & -0.115 & -0.173 & -0.129 \\
\hline & $(0.088)$ & $(0.088)$ & $(0.194)$ & $(0.139)$ & $(0.196)$ & $(0.109)$ & $(0.107)$ & $(0.205)$ & $(0.149)$ & $(0.203)$ \\
\hline $\ln \left(\mathrm{LS}_{\text {Female/Male }}\right) \times$ High & -0.212 & -0.219 & -0.194 & -0.181 & -0.161 & -0.279 & -0.246 & -0.154 & -0.153 & -0.140 \\
\hline & $(0.070)$ & $(0.086)$ & $(0.184)$ & $(0.119)$ & $(0.179)$ & $(0.097)$ & $(0.095)$ & $(0.178)$ & $(0.117)$ & $(0.173)$ \\
\hline $\ln \left(\mathrm{LS}_{\text {High-School-Male/ }}\right.$ & & & & -0.036 & -0.104 & & & & -0.070 & -0.145 \\
\hline LS $\left._{8 \text { th-Male }}\right) \times$ High School & & & & $(0.064)$ & $(0.065)$ & & & & $(0.057)$ & $(0.072)$ \\
\hline 1st Sta & 1.99 & 2.01 & 1.14 & 1.54 & 1.13 & 1.64 & 1.80 & 1.20 & 1.56 & 1.20 \\
\hline (Mobilization Rate x 1950) & $(0.21)$ & $(0.27)$ & $(0.26)$ & $(0.26)$ & $(0.25)$ & $(0.20)$ & $(0.24)$ & $(0.30)$ & $(0.26)$ & $(0.30)$ \\
\hline Implied relative cross- & 2.24 & 2.07 & 3.63 & 2.12 & 2.63 & 2.45 & 2.12 & 2.34 & 1.89 & 2.09 \\
\hline $\mathrm{n}$ & & & 96,797 & & & & & 93,244 & & \\
\hline $\mathrm{p}$-value of $\mathrm{H}_{0}: \Delta \mathrm{W}_{\mathrm{HS}}=0$ & 0.00 & 0.00 & 0.24 & 0.02 & 0.00 & 0.00 & 0.00 & 0.24 & 0.04 & 0.24 \\
\hline Female Age & No & Yes & Yes & Yes & Yes & No & Yes & Yes & Yes & Yes \\
\hline Birth State, Married, & No & Yes & Yes & Yes & Yes & No & Yes & Yes & Yes & Yes \\
\hline Farm/Non-white/ Avg Ed & No & No & Yes & No & Yes & No & No & Yes & No & Yes \\
\hline
\end{tabular}

Standard errors in parentheses account for clustering on state and year of observation. Samples and specifications are analogous to Table 10 except: sample in Panel A is restricted to males with exactly a college or high school degree; sample in Panel B is restricted to males with exactly a high school degree or 8th grade completion; in addition to time interactions on all individual level controls, all variables are interacted with college graduate dummy in Panel A and high school graduate dummy in Panel B. Log (female/male) labor supply measured in weeks and its interaction with college or high school dummy and a 1950 dummy are instrumented by state mobilization rate and its interaction with college or high school dummy. All individual and aggregate controls are included in first stage of IV models. 
Table 12. IV Estimates: Impact of Female Labor Supply on Overall and Residual Earnings Inequality 1940 - 1950 Dependent Variable: Change in State Level Estimated Log Earnings Differentials

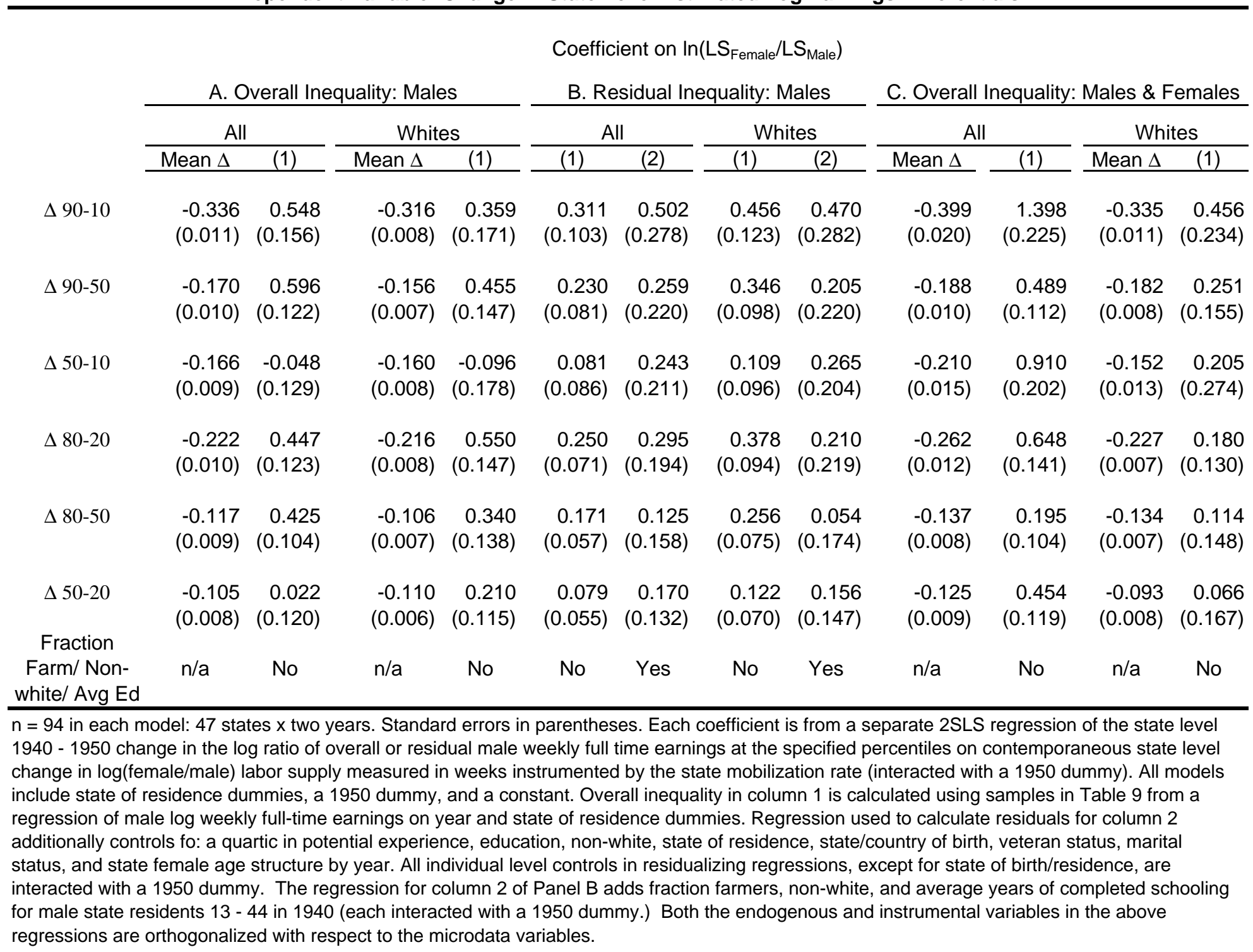


Appendix Table 1. Alternative Estimates of Impact of World War II Mobilization Rates on Decadal Changes in State Labor Supply, 1940 - 1950.

Coefficient on Mobilization Rate x 1950 Variable Tabulated in Each Panel

A. Dependent Variable: Weeks Worked Per Woman: Mobilization Rate Assigned by State of Birth

\begin{tabular}{crrrrr}
\hline & \multicolumn{2}{c}{ All } & \multicolumn{2}{c}{ White } \\
& $(1)$ & $(2)$ & $(3)$ & $(4)$ \\
Weeks worked in previous year & 8.72 & 11.24 & 9.25 & 10.82 \\
& $(2.29)$ & $(3.02)$ & $(1.83)$ & $(3.16)$ \\
Positive weeks in previous year & 0.002 & 0.274 & 0.033 & 0.251 \\
& $(0.065)$ & $(0.078)$ & \multicolumn{2}{c}{$(0.053)$} & $(0.082)$ \\
$\mathrm{n}$ & \multicolumn{2}{c}{524,634} & \multicolumn{2}{c}{470,326}
\end{tabular}

B. Dependent Variable: Total (Log) Female Labor Supply by State, 1940 - 1950

(2)

White

\begin{tabular}{|c|c|c|c|c|}
\hline & (1) & (2) & (1) & (2) \\
\hline Aggregate Weeks & $\begin{array}{r}1.77 \\
(0.64)\end{array}$ & $\begin{array}{r}1.14 \\
(0.88)\end{array}$ & $\begin{array}{r}0.96 \\
(0.71)\end{array}$ & $\begin{array}{r}1.64 \\
(0.94)\end{array}$ \\
\hline Aggregate Efficiency Units & $\begin{array}{r}1.35 \\
(0.62)\end{array}$ & $\begin{array}{r}1.33 \\
(0.88)\end{array}$ & $\begin{array}{r}1.04 \\
(0.67)\end{array}$ & $\begin{array}{r}1.70 \\
(0.91)\end{array}$ \\
\hline
\end{tabular}

C. Dependent Variable: Total (Log) Male Labor Supply by State, 1940 - 1950

(2)

White

\begin{tabular}{|c|c|c|c|c|}
\hline & (1) & (2) & (1) & (2) \\
\hline Aggregate Weeks & $\begin{array}{c}-0.54 \\
(0.59)\end{array}$ & $\begin{array}{r}0.11 \\
(0.72)\end{array}$ & $\begin{array}{c}-0.73 \\
(0.62)\end{array}$ & $\begin{array}{r}0.42 \\
(0.72)\end{array}$ \\
\hline Aggregate Efficiency Units & $\begin{array}{c}-0.49 \\
(0.57)\end{array}$ & $\begin{array}{r}0.21 \\
(0.71)\end{array}$ & $\begin{array}{r}-0.57 \\
(0.59)\end{array}$ & $\begin{array}{r}0.41 \\
(0.70)\end{array}$ \\
\hline & & & & \\
\hline
\end{tabular}

Fraction Farmer/Non-white/Avg Ed

No

Yes

No $\quad$ Yes

Notes for Panel A. Standard errors in parenthesis account for clustering on state of residence and year of observation. Each column is from a separate pooled $1940-1950$ microdata regression of weeks worked by female state residents on WWII state mobilization rate interacted with a 1950 dummy, a year main effect, a constant, and dummies for: non-white (where relevant), age, marital status, state of residence, and state/country of birth. All individual demographic variables, aside from state of residence/birth, are also interacted with a 1950 dummy. State mobilization rate is assigned by female state of birth. As indicated, models also control for state fraction farmers, nonwhite, and average education among males ages 13 - 44 in 1940 in state of birth (each interacted with a 1950 dummy.)

Notes for Panels B and C. Each coefficient is from a separate regression of log total state labor supply in weeks or efficiency units by gender and year on the state mobilization rate (interacted with a 1950 dummy), state dummies, a year main effect, and a constant. Regressions are weighted by state-gender population ages 18-64 in each year. As indicated, models also control for state fraction farmers, non-white, and average education among males ages 13 - 44 in 1940 in state of residence (each interacted with a 1950 dummy.) 


\section{Appendix Table 2. Impact of World War II Mobilization Rates on Female Labor Supply by Age and Education: 1940 - 1950. Dependent Variable: Annual Weeks Worked}

\begin{tabular}{|c|c|c|c|c|}
\hline & \multicolumn{4}{|c|}{ Coefficient on Mobilization Rate Variable x 1950} \\
\hline & \multicolumn{2}{|c|}{ All Females } & \multicolumn{2}{|c|}{ White Females } \\
\hline & \multicolumn{4}{|c|}{ A. Weeks Worked by Age Group } \\
\hline & (1) & $(2)$ & (3) & $(4)$ \\
\hline All $14-64$ & $\begin{array}{c}9.06 \\
(2.35)\end{array}$ & $\begin{array}{c}8.28 \\
(2.39)\end{array}$ & $\begin{array}{c}9.85 \\
(2.05)\end{array}$ & $\begin{array}{c}8.73 \\
(2.39)\end{array}$ \\
\hline Ages $14-17$ & $\begin{array}{c}1.38 \\
(0.35)\end{array}$ & $\begin{array}{l}1.20 \\
(0.42)\end{array}$ & $\begin{array}{l}1.41 \\
(0.32)\end{array}$ & $\begin{array}{c}0.88 \\
(0.39)\end{array}$ \\
\hline Ages $18-24$ & $\begin{array}{l}2.35 \\
(0.94)\end{array}$ & $\begin{array}{c}4.85 \\
(1.19)\end{array}$ & $\begin{array}{l}2.24 \\
(0.99)\end{array}$ & $\begin{array}{c}5.06 \\
(1.32)\end{array}$ \\
\hline Ages $25-34$ & $\begin{array}{c}1.26 \\
(0.95)\end{array}$ & $\begin{array}{c}2.16 \\
(1.55)\end{array}$ & $\begin{array}{c}0.57 \\
(0.88)\end{array}$ & $\begin{array}{c}2.00 \\
(1.58)\end{array}$ \\
\hline Ages $35-44$ & $\begin{array}{c}1.89 \\
(0.72)\end{array}$ & $\begin{array}{l}2.32 \\
(0.93)\end{array}$ & $\begin{array}{c}2.41 \\
(0.73)\end{array}$ & $\begin{array}{l}2.31 \\
(0.93)\end{array}$ \\
\hline Ages $45-54$ & $\begin{array}{c}1.54 \\
(1.10)\end{array}$ & $\begin{array}{l}-2.10 \\
(1.56)\end{array}$ & $\begin{array}{c}2.23 \\
(1.05)\end{array}$ & $\begin{array}{l}-1.44 \\
(1.55)\end{array}$ \\
\hline \multirow[t]{2}{*}{ Ages $55-64$} & $\begin{array}{c}0.65 \\
(0.99)\end{array}$ & $\begin{array}{l}-0.15 \\
(1.08)\end{array}$ & $\begin{array}{l}1.00 \\
(0.96)\end{array}$ & $\begin{array}{l}-0.08 \\
(1.05)\end{array}$ \\
\hline & \multicolumn{4}{|c|}{ B. Weeks Worked by Education Group } \\
\hline 8th Grade and Below & $\begin{array}{l}-2.27 \\
(1.97)\end{array}$ & $\begin{array}{l}-0.79 \\
(1.78)\end{array}$ & $\begin{array}{l}-1.05 \\
(1.47)\end{array}$ & $\begin{array}{l}-0.82 \\
(1.76)\end{array}$ \\
\hline $\begin{array}{c}\text { 9th Grade to 11th } \\
\text { Grade }\end{array}$ & $\begin{array}{l}-2.44 \\
(1.53)\end{array}$ & $\begin{array}{c}1.93 \\
(1.56)\end{array}$ & $\begin{array}{l}-2.75 \\
(1.51)\end{array}$ & $\begin{array}{c}1.75 \\
(1.49)\end{array}$ \\
\hline 12th Grade and Above & $\begin{array}{l}13.78 \\
(1.77)\end{array}$ & $\begin{array}{c}7.13 \\
(1.79)\end{array}$ & $\begin{array}{l}13.65 \\
(1.85)\end{array}$ & $\begin{array}{c}7.81 \\
(2.02)\end{array}$ \\
\hline $\mathrm{n}$ & \multicolumn{2}{|c|}{585,745} & \multicolumn{2}{|c|}{530,026} \\
\hline $\begin{array}{c}\text { Fraction Farm, Non- } \\
\text { white, Avg Ed }\end{array}$ & No & Yes & No & Yes \\
\hline
\end{tabular}

Standard errors in parenthesis account for clustering on state of residence and year of observation. Each entry is from a separate pooled microdata regression for the relevant demographic subgroup of female weeks worked by state of residence on state mobilization rate interacted with a 1950 dummy, a year main effect, a constant, and dummies for non-white (where relevant), age, marital status, state of residence, and state/country of birth. All individual demographic variables, aside from state of residence/birth, are also interacted with a 1950 dummy. As indicated, models also control for state fraction farmers, non-white, and average education among males ages 13 - 44 in 1940 in women's state of residence (each interacted with a 1950 dummy). Education categories reflect the highest grade completed. 
Appendix Table 3. Impact of World War II Mobilization Rates on Female Labor Supply by Cohort: 1940 - 1950.

Dependent Variable: Annual Weeks Worked

\begin{tabular}{|c|c|c|c|c|}
\hline \multirow{3}{*}{$\begin{array}{c}\text { Cohorts } \\
\text { Ages } 14-24(1940) \\
\text { Ages } 24-34(1950) \\
n\end{array}$} & \multicolumn{4}{|c|}{$\begin{array}{l}\text { Coefficient on Mobilization Rate Variable x } 1950 \\
\text { All }\end{array}$} \\
\hline & \multirow{2}{*}{\multicolumn{2}{|c|}{$\begin{array}{cc}6.11 & 19.02 \\
(5.24) & (5.48) \\
155,272\end{array}$}} & \multirow{2}{*}{\multicolumn{2}{|c|}{$\begin{array}{cr}4.16 & 1 \varepsilon \\
(5.25) & (5 \\
138,870\end{array}$}} \\
\hline & & & & \\
\hline $\begin{array}{l}\text { Ages } 25-34(1940) \\
\text { Ages } 35-44(1950)\end{array}$ & $\begin{array}{l}-3.52 \\
(4.04)\end{array}$ & \multirow{2}{*}{$\begin{array}{l}16.84 \\
(6.14) \\
93\end{array}$} & $\begin{array}{l}-2.33 \\
(3.55)\end{array}$ & \multirow{2}{*}{$\begin{array}{l}16.21 \\
(6.53) \\
83\end{array}$} \\
\hline $\mathrm{n}$ & 135,893 & & 122,083 & \\
\hline $\begin{array}{l}\text { Ages } 35-44(1940) \\
\text { Ages } 45-54(1950)\end{array}$ & $\begin{array}{l}21.16 \\
(5.39)\end{array}$ & $\begin{array}{l}15.19 \\
(7.38)\end{array}$ & $\begin{array}{l}23.42 \\
(5.40)\end{array}$ & $\begin{array}{l}17.76 \\
(7.23)\end{array}$ \\
\hline $\mathrm{n}$ & \multicolumn{2}{|c|}{115,025} & \multicolumn{2}{|c|}{103,918} \\
\hline $\begin{array}{l}\text { Ages } 45-54(1940) \\
\text { Ages } 55-64(1950)\end{array}$ & $\begin{array}{l}11.56 \\
(5.82)\end{array}$ & $\begin{array}{l}-8.19 \\
(5.22)\end{array}$ & $\begin{array}{l}13.91 \\
(5.46)\end{array}$ & $\begin{array}{l}-6.45 \\
(4.75)\end{array}$ \\
\hline $\mathrm{n}$ & \multicolumn{2}{|c|}{100,125} & \multicolumn{2}{|c|}{92,550} \\
\hline $\begin{array}{l}\text { Fraction Farm, Non- } \\
\text { white, Avg Ed }\end{array}$ & No & Yes & No & Yes \\
\hline
\end{tabular}

Standard errors in parenthesis account for clustering on state of residence and year of observation. Each entry is from a separate pooled 1940 - 1950 microdata regression of individual weeks worked by females from the listed cohort on state mobilization rate interacted with a 1950 dummy, a year main effect, a constant, and dummies for: non-white (where relevant), age, marital status, state of residence, and state/country of birth. All individual demographic variables, aside from state of residence/birth, are also interacted with a 1950 dummy. As indicated, models also control for state fraction farmers, non-white, and average education among males ages 13 - 44 in 1940 in female's state of residence (each interacted with a 1950 dummy). Mobilization rate is assigned by female state of residence. 
Appendix Table 4. IV Specifications: Impact of Female Labor Supply on Female and Male Earnings 1940 - 1950:

Dropping the South and Adding 4 Region x 1950 Dummies Dependent Variable: Log Weekly Earnings

\begin{tabular}{|c|c|c|c|c|c|c|c|c|c|c|c|c|}
\hline & \multirow{2}{*}{\multicolumn{12}{|c|}{ A. Full-Time Weekly Earnings: All }} \\
\hline & \multicolumn{6}{|c|}{ Females } & Males & & & & & \\
\hline & $(1)$ & $(2)$ & (3) & $(4)$ & $(5)$ & (6) & (7) & (8) & (9) & $(10)$ & (11) & $(12)$ \\
\hline IV - Weeks Worked per Woman & $\begin{array}{r}-0.103 \\
(0.023)\end{array}$ & $\begin{array}{r}-0.068 \\
(0.041)\end{array}$ & $\begin{array}{r}-0.041 \\
(0.021)\end{array}$ & $\begin{array}{r}0.018 \\
(0.022)\end{array}$ & $\begin{array}{r}-0.158 \\
(0.035)\end{array}$ & $\begin{array}{r}-0.145 \\
(0.075)\end{array}$ & $\begin{array}{r}-0.061 \\
(0.014)\end{array}$ & $\begin{array}{r}-0.023 \\
(0.019)\end{array}$ & $\begin{array}{r}-0.030 \\
(0.015)\end{array}$ & $\begin{array}{r}0.012 \\
(0.013)\end{array}$ & $\begin{array}{r}-0.064 \\
(0.020)\end{array}$ & $\begin{array}{r}-0.032 \\
(0.023)\end{array}$ \\
\hline $\begin{array}{c}\text { 1st Stage Coefficient } \\
\text { (Mobilization Rate x 1950) }\end{array}$ & $\begin{array}{l}13.02 \\
(2.39)\end{array}$ & $\begin{array}{r}9.35 \\
(2.70)\end{array}$ & $\begin{array}{r}14.70 \\
(4.15)\end{array}$ & $\begin{array}{l}14.05 \\
(3.76)\end{array}$ & $\begin{array}{l}11.22 \\
(1.96)\end{array}$ & $\begin{array}{r}7.21 \\
(3.00)\end{array}$ & $\begin{array}{l}13.10 \\
(2.37)\end{array}$ & $\begin{array}{r}9.76 \\
(2.67)\end{array}$ & $\begin{array}{l}15.34 \\
(4.01)\end{array}$ & $\begin{array}{r}14.07 \\
(3.97)\end{array}$ & $\begin{array}{r}11.19 \\
(1.93)\end{array}$ & $\begin{array}{r}7.65 \\
(2.80)\end{array}$ \\
\hline OLS -Weeks Worked per Woman & $\begin{array}{r}-0.007 \\
(0.010)\end{array}$ & $\begin{array}{r}0.007 \\
(0.006)\end{array}$ & $\begin{array}{r}0.000 \\
(0.007)\end{array}$ & $\begin{array}{r}0.010 \\
(0.006)\end{array}$ & $\begin{array}{l}-0.035 \\
(0.015)\end{array}$ & $\begin{array}{r}0.005 \\
(0.008)\end{array}$ & $\begin{array}{r}-0.008 \\
(0.006)\end{array}$ & $\begin{array}{r}0.004 \\
(0.003)\end{array}$ & $\begin{array}{r}-0.005 \\
(0.004)\end{array}$ & $\begin{array}{r}0.004 \\
(0.003)\end{array}$ & $\begin{array}{r}-0.014 \\
(0.008)\end{array}$ & $\begin{array}{r}0.006 \\
(0.007)\end{array}$ \\
\hline \multirow[t]{3}{*}{$\mathrm{n}$} & \multicolumn{4}{|c|}{78,094} & \multicolumn{2}{|c|}{58,727} & \multicolumn{4}{|c|}{213,966} & \multicolumn{2}{|c|}{161,683} \\
\hline & \multicolumn{12}{|c|}{ B. Full-Time Weekly Earnings: Whites } \\
\hline & $(1)$ & $(2)$ & (3) & $(4)$ & (5) & $(6)$ & \multicolumn{6}{|c|}{ Males } \\
\hline IV - Weeks Worked per Woman & $\begin{array}{r}-0.108 \\
(0.025)\end{array}$ & $\begin{array}{r}-0.072 \\
(0.038)\end{array}$ & $\begin{array}{r}-0.018 \\
(0.028)\end{array}$ & $\begin{array}{r}0.001 \\
(0.022)\end{array}$ & $\begin{array}{r}-0.155 \\
(0.033)\end{array}$ & $\begin{array}{r}-0.135 \\
(0.071)\end{array}$ & $\begin{array}{r}-0.071 \\
(0.015)\end{array}$ & $\begin{array}{l}-0.021 \\
(0.017)\end{array}$ & $\begin{array}{r}-0.024 \\
(0.017)\end{array}$ & $\begin{array}{r}0.014 \\
(0.013)\end{array}$ & $\begin{array}{r}-0.063 \\
(0.018)\end{array}$ & $\begin{array}{r}-0.031 \\
(0.022)\end{array}$ \\
\hline $\begin{array}{c}\text { 1st Stage Coefficient } \\
\text { (Mobilization Rate x 1950) }\end{array}$ & $\begin{array}{l}11.68 \\
(2.14)\end{array}$ & $\begin{array}{l}11.20 \\
(2.72)\end{array}$ & $\begin{array}{l}11.84 \\
(3.80)\end{array}$ & $\begin{array}{l}15.05 \\
(4.03)\end{array}$ & $\begin{array}{l}11.64 \\
(1.99)\end{array}$ & $\begin{array}{r}8.04 \\
(3.08)\end{array}$ & $\begin{array}{l}11.65 \\
(2.16)\end{array}$ & $\begin{array}{l}11.44 \\
(2.73)\end{array}$ & $\begin{array}{l}11.76 \\
(3.81)\end{array}$ & $\begin{array}{l}14.46 \\
(4.08)\end{array}$ & $\begin{array}{l}11.41 \\
(1.99)\end{array}$ & $\begin{array}{r}8.28 \\
(2.86)\end{array}$ \\
\hline OLS -Weeks Worked per Woman & $\begin{array}{r}-0.012 \\
(0.010)\end{array}$ & $\begin{array}{r}-0.001 \\
(0.007)\end{array}$ & $\begin{array}{r}0.008 \\
(0.008)\end{array}$ & $\begin{array}{r}0.008 \\
(0.006)\end{array}$ & $\begin{array}{r}-0.033 \\
(0.016)\end{array}$ & $\begin{array}{r}0.002 \\
(0.007)\end{array}$ & $\begin{array}{r}-0.009 \\
(0.006)\end{array}$ & $\begin{array}{r}0.000 \\
(0.003)\end{array}$ & $\begin{array}{r}0.001 \\
(0.005)\end{array}$ & $\begin{array}{r}0.003 \\
(0.003)\end{array}$ & $\begin{array}{r}-0.016 \\
(0.008)\end{array}$ & $\begin{array}{r}0.002 \\
(0.006)\end{array}$ \\
\hline $\mathrm{n}$ & \multicolumn{4}{|c|}{69,335} & \multicolumn{2}{|c|}{55,847} & \multicolumn{4}{|c|}{198,385} & \multicolumn{2}{|c|}{155,743} \\
\hline Fraction Farm/Non-white/Avg Ed & No & Yes & No & Yes & No & Yes & No & Yes & No & Yes & No & Yes \\
\hline Region x 1950 Dummies & No & No & Yes & Yes & No & No & No & No & Yes & Yes & No & No \\
\hline Excluding South & No & No & No & No & Yes & Yes & No & No & No & No & Yes & Yes \\
\hline
\end{tabular}

Standard errors in parentheses account for clustering on state and year of observation. Samples and specifications are identical to Table 9 columns 3 and 4 (females) and columns 7 and 8 (males) except as noted for addition of 4 Census main geographic dummies (interacted with a 1950 dummy) and dropping of the Southern region in columns 5, 6, 11 and 12 (VA, AL, AR, FL, MS, NC, SC, TX, KY, MD, OK, TN, and WV). 


\section{Appendix Table 5. Lagged Dependent Variable IV Specifications: Impact of Female Labor Supply on \\ Female and Male Earnings 1940 - 1950 \\ Dependent Variable: Log Weekly Earnings}

\begin{tabular}{|c|c|c|c|c|c|c|c|c|}
\hline & \multicolumn{8}{|c|}{ A. Full-Time Weekly Earnings: All } \\
\hline & \multicolumn{4}{|c|}{ Females } & \multicolumn{4}{|c|}{ Males } \\
\hline & $(1)$ & $(2)$ & (3) & $(4)$ & $(5)$ & (6) & $(7)$ & $(8)$ \\
\hline IV - Weeks Worked per Woman & $\begin{array}{r}-0.095 \\
(0.038)\end{array}$ & $\begin{array}{r}-0.078 \\
(0.030)\end{array}$ & $\begin{array}{r}-0.078 \\
(0.030)\end{array}$ & $\begin{array}{r}-0.131 \\
(0.049)\end{array}$ & $\begin{array}{r}-0.068 \\
(0.022)\end{array}$ & $\begin{array}{r}-0.051 \\
(0.017)\end{array}$ & $\begin{array}{r}-0.052 \\
(0.018)\end{array}$ & $\begin{array}{l}-0.029 \\
(0.018)\end{array}$ \\
\hline $\begin{array}{c}\text { Lagged Dependent Variable } \\
\text { (1940 State Mean Log Wage x 1950) }\end{array}$ & $\begin{array}{r}-0.033 \\
(0.084)\end{array}$ & $\begin{array}{r}-0.085 \\
(0.063)\end{array}$ & $\begin{array}{r}-0.084 \\
(0.062)\end{array}$ & $\begin{array}{r}-0.402 \\
(0.153)\end{array}$ & $\begin{array}{r}0.025 \\
(0.073)\end{array}$ & $\begin{array}{r}-0.048 \\
(0.059)\end{array}$ & $\begin{array}{r}-0.046 \\
(0.060)\end{array}$ & $\begin{array}{r}-0.062 \\
(0.071)\end{array}$ \\
\hline $\begin{array}{c}\text { 1st Stage Coefficient } \\
\text { (Mobilization Rate x 1950) }\end{array}$ & $\begin{array}{r}9.40 \\
(2.07)\end{array}$ & $\begin{array}{l}10.24 \\
(2.59)\end{array}$ & $\begin{array}{l}10.23 \\
(2.59)\end{array}$ & $\begin{array}{r}8.87 \\
(2.74)\end{array}$ & $\begin{array}{r}7.82 \\
(2.08)\end{array}$ & $\begin{array}{r}9.38 \\
(2.29)\end{array}$ & $\begin{array}{r}9.37 \\
(2.29)\end{array}$ & $\begin{array}{l}11.85 \\
(3.19)\end{array}$ \\
\hline \multirow[t]{4}{*}{$n$} & \multicolumn{4}{|c|}{78,094} & \multicolumn{4}{|c|}{213,966} \\
\hline & \multicolumn{8}{|c|}{ B. Full-Time Weekly Earnings: Whites } \\
\hline & \multicolumn{4}{|c|}{ Females } & \multicolumn{4}{|c|}{ Males } \\
\hline & $(1)$ & $(2)$ & (3) & (4) & $(5)$ & $(6)$ & (7) & $(8)$ \\
\hline IV - Weeks Worked per Woman & $\begin{array}{r}-0.070 \\
(0.028)\end{array}$ & $\begin{array}{r}-0.057 \\
(0.023)\end{array}$ & $\begin{array}{r}-0.057 \\
(0.024)\end{array}$ & $\begin{array}{r}-0.097 \\
(0.034)\end{array}$ & $\begin{array}{r}-0.060 \\
(0.018)\end{array}$ & $\begin{array}{r}-0.047 \\
(0.015)\end{array}$ & $\begin{array}{r}-0.049 \\
(0.016)\end{array}$ & $\begin{array}{r}-0.029 \\
(0.017)\end{array}$ \\
\hline $\begin{array}{c}\text { Lagged Dependent Variable } \\
\text { (1940 State Mean Log Wage x 1950) }\end{array}$ & $\begin{array}{r}-0.284 \\
(0.074)\end{array}$ & $\begin{array}{r}-0.275 \\
(0.052)\end{array}$ & $\begin{array}{r}-0.277 \\
(0.053)\end{array}$ & $\begin{array}{r}-0.360 \\
(0.113)\end{array}$ & $\begin{array}{l}-0.102 \\
(0.063)\end{array}$ & $\begin{array}{r}-0.148 \\
(0.048)\end{array}$ & $\begin{array}{r}-0.143 \\
(0.051)\end{array}$ & $\begin{array}{l}-0.093 \\
(0.077)\end{array}$ \\
\hline $\begin{array}{c}\text { 1st Stage Coefficient } \\
\text { (Mobilization Rate } \times 1950 \text { ) }\end{array}$ & $\begin{array}{r}10.22 \\
(1.64)\end{array}$ & $\begin{array}{l}11.73 \\
(2.49)\end{array}$ & $\begin{array}{l}11.71 \\
(2.49)\end{array}$ & $\begin{array}{l}11.10 \\
(2.60)\end{array}$ & $\begin{array}{r}8.90 \\
(1.84)\end{array}$ & $\begin{array}{l}10.78 \\
(2.21)\end{array}$ & $\begin{array}{l}10.77 \\
(2.21)\end{array}$ & $\begin{array}{r}12.88 \\
(3.22)\end{array}$ \\
\hline & \multicolumn{4}{|c|}{69,335} & \multicolumn{4}{|c|}{198,385} \\
\hline Female Age Structure & No & Yes & Yes & Yes & No & Yes & Yes & Yes \\
\hline State of Birth & No & No & Yes & Yes & No & No & Yes & Yes \\
\hline Fraction Farm/Non-white/Avg Ed & No & No & No & Yes & No & No & No & Yes \\
\hline
\end{tabular}

Standard errors in parentheses account for clustering on state and year of observation. Each column is from a separate pooled 1940 - 1950 microdata regression of log weekly earnings on weeks worked per female by state of residence instrumented by state mobilization rate (interacted with 1950 dummy). The lagged dependent variable is equal to the 1940 state mean log weekly full-time wage for the relevant gender/race group interacted with a 1950 dummy.

Specifications and control variables are otherwise identical to Table 9. 


\section{Appendix Table 6. IV Estimated Impact of Female Labor Supply on Female/Male Earnings Differential 1940 - 1960 \\ Dependent Variable: Full-Time Log Weekly Earnings}

\begin{tabular}{|c|c|c|c|c|c|c|c|c|}
\hline & \multicolumn{4}{|c|}{ A. All } & \multicolumn{4}{|c|}{ B. Whites } \\
\hline & (1) & $(2)$ & (3) & (4) & (1) & (2) & (3) & (4) \\
\hline $\ln \left(\mathrm{LS}_{\mathrm{Female}} / \mathrm{LS}_{\text {Male }}\right)$ & $\begin{array}{r}-0.385 \\
(0.089)\end{array}$ & $\begin{array}{l}-0.579 \\
(0.168)\end{array}$ & $\begin{array}{r}-0.583 \\
(0.171)\end{array}$ & $\begin{array}{r}20.1 \\
(311.8)\end{array}$ & $\begin{array}{r}-0.707 \\
(0.194)\end{array}$ & $\begin{array}{l}-0.837 \\
(0.259)\end{array}$ & $\begin{array}{r}-0.845 \\
(0.267)\end{array}$ & $\begin{array}{r}-1.410 \\
(1.265)\end{array}$ \\
\hline $\begin{array}{c}\ln \left(\mathrm{LS}_{\text {Female }} / \mathrm{LS}_{\text {Male }}\right) \\
\times \text { Female }\end{array}$ & $\begin{array}{r}-0.039 \\
(0.105)\end{array}$ & $\begin{array}{l}-0.028 \\
(0.122)\end{array}$ & $\begin{array}{r}-0.014 \\
(0.114)\end{array}$ & $\begin{array}{r}13.0 \\
(291.5)\end{array}$ & $\begin{array}{r}0.094 \\
(0.171)\end{array}$ & $\begin{array}{r}0.138 \\
(0.200)\end{array}$ & $\begin{array}{r}0.156 \\
(0.191)\end{array}$ & $\begin{array}{r}-1.733 \\
(4.184)\end{array}$ \\
\hline $\begin{array}{c}\text { 1st Stage Coefficient } \\
\text { (Mobilization Rate x 1960) }\end{array}$ & $\begin{array}{r}2.10 \\
(0.39)\end{array}$ & $\begin{array}{r}1.77 \\
(0.47)\end{array}$ & $\begin{array}{r}1.77 \\
(0.47)\end{array}$ & $\begin{array}{r}-0.03 \\
(0.42)\end{array}$ & $\begin{array}{r}1.17 \\
(0.32)\end{array}$ & $\begin{array}{r}1.06 \\
(0.35)\end{array}$ & $\begin{array}{r}1.06 \\
(0.35)\end{array}$ & $\begin{array}{r}0.24 \\
(0.40)\end{array}$ \\
\hline Implied Female Demand $\sigma_{\mathrm{F}}$ & -2.36 & -1.65 & -1.68 & 0.03 & -1.63 & -1.43 & -1.45 & -0.32 \\
\hline Implied M/F Substition $\sigma_{\mathrm{M} / \mathrm{F}}$ & -25.48 & -36.36 & -69.99 & $\mathrm{n} / \mathrm{a}$ & $\mathrm{n} / \mathrm{a}$ & $\mathrm{n} / \mathrm{a}$ & $\mathrm{n} / \mathrm{a}$ & -0.58 \\
\hline$p$-value of $H_{0}:\left(\sigma_{F}\right)^{-1}=0$ & 0.02 & 0.03 & 0.03 & 0.96 & 0.07 & 0.10 & 0.10 & 0.55 \\
\hline $\mathrm{n}$ & \multicolumn{4}{|c|}{566,221} & \multicolumn{4}{|c|}{517,458} \\
\hline Female Age Structure & No & Yes & Yes & Yes & No & Yes & Yes & Yes \\
\hline State of Birth & No & No & Yes & Yes & No & No & Yes & Yes \\
\hline Farm/Non-white/Avg Ed & No & No & No & Yes & No & No & No & Yes \\
\hline
\end{tabular}

Standard errors in parentheses account for clustering on state and year of observation. Each column is from a separate pooled 1940 and 1960 microdata regression of log weekly male and female earnings on the log ratio of female to male non-farm labor supply in weeks instrumented by the state mobilization rate interacted with a 1960 dummy. Sample definition and specifications are identical to Table 10 columns 1 - 4 except that 1960 Census data is used in place of 1950 Census data. 


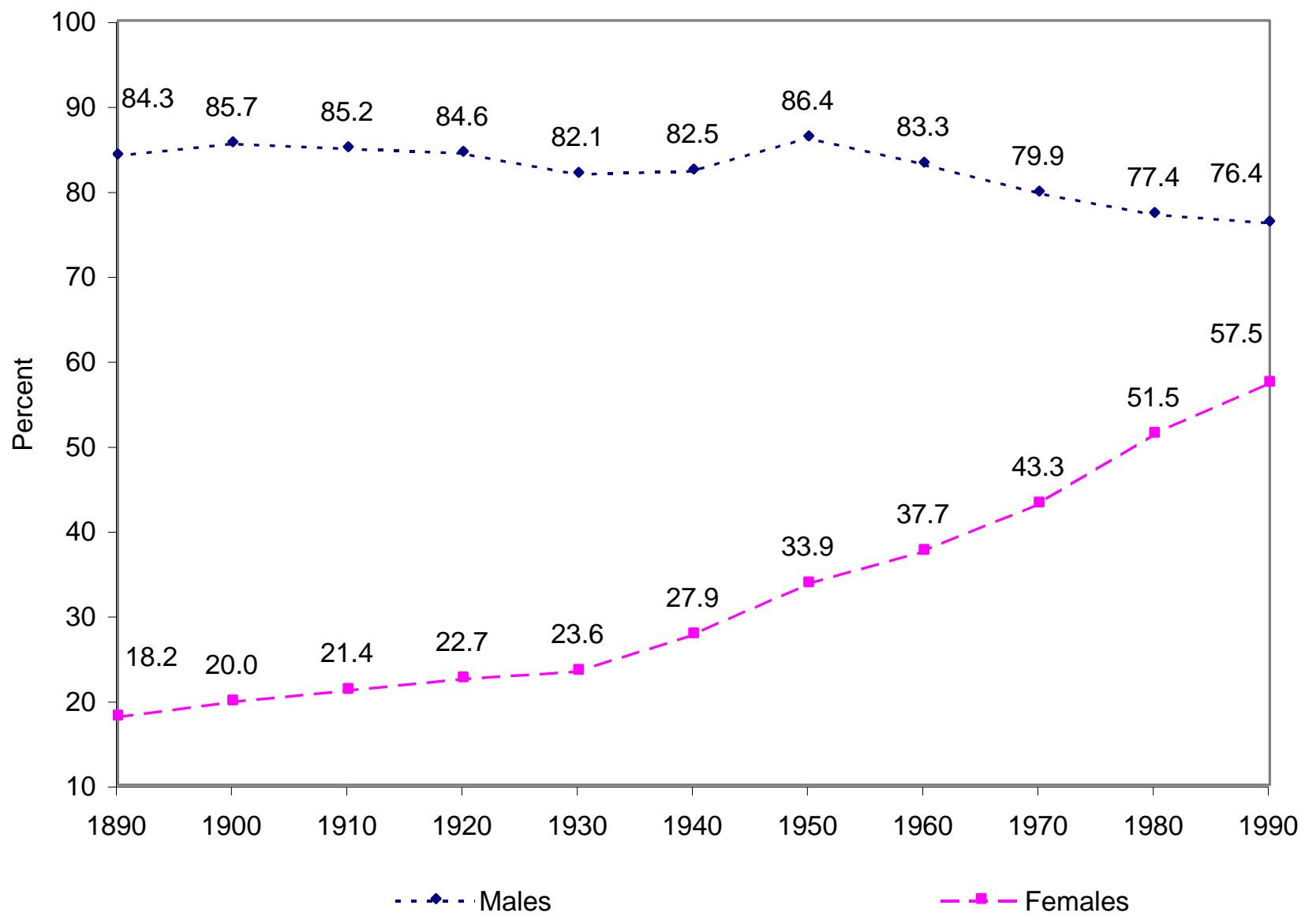

Figure 1. Labor Force Participation by Gender of U.S. Residents Ages 16 - 65, 1890 - 1990. Source: Blau, Ferber and Winkler (2000), Table 4.1 


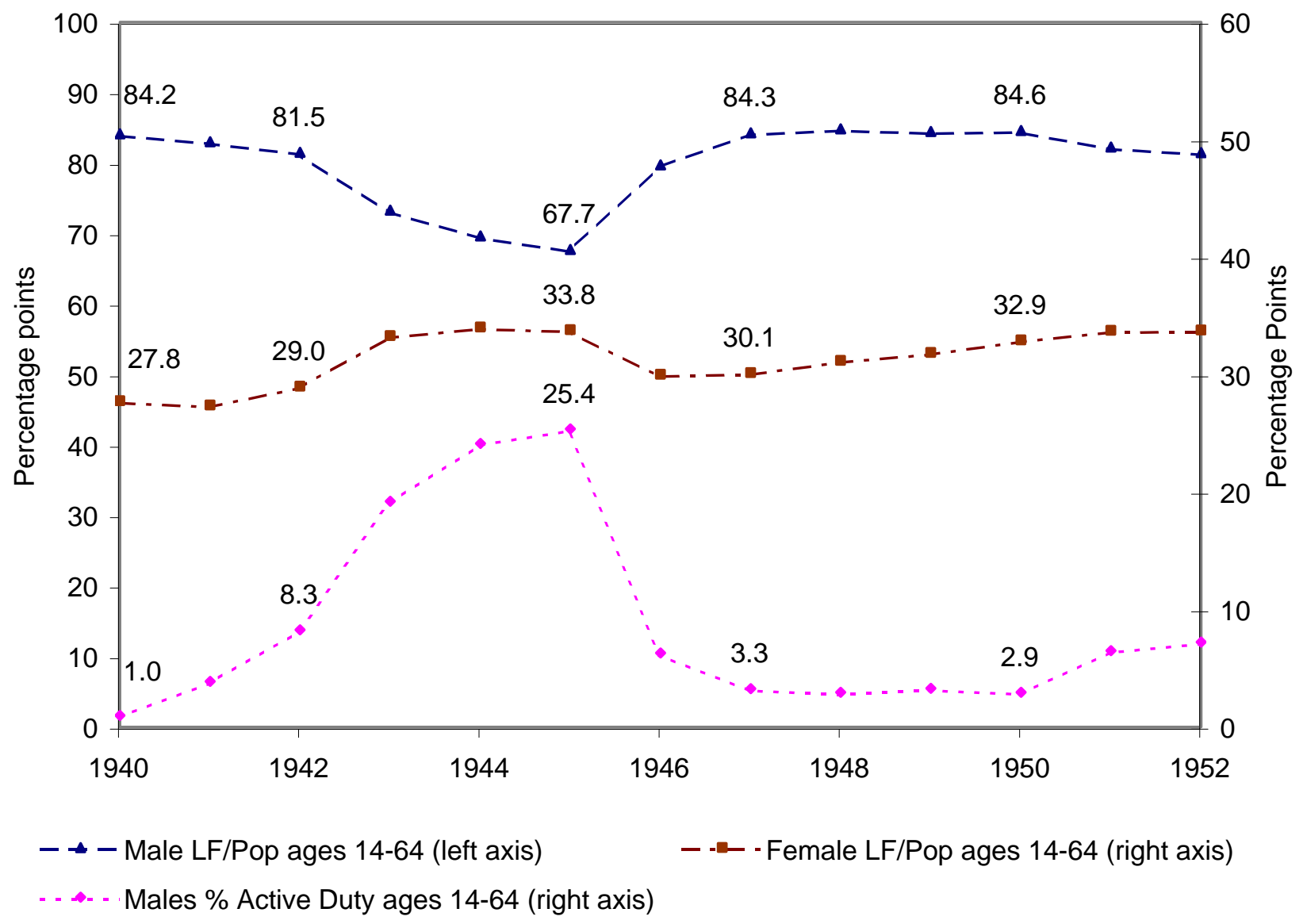

Figure 2. Male and Female Labor Force Participation and Military Active Service Personnel, 1940 - 1952. 

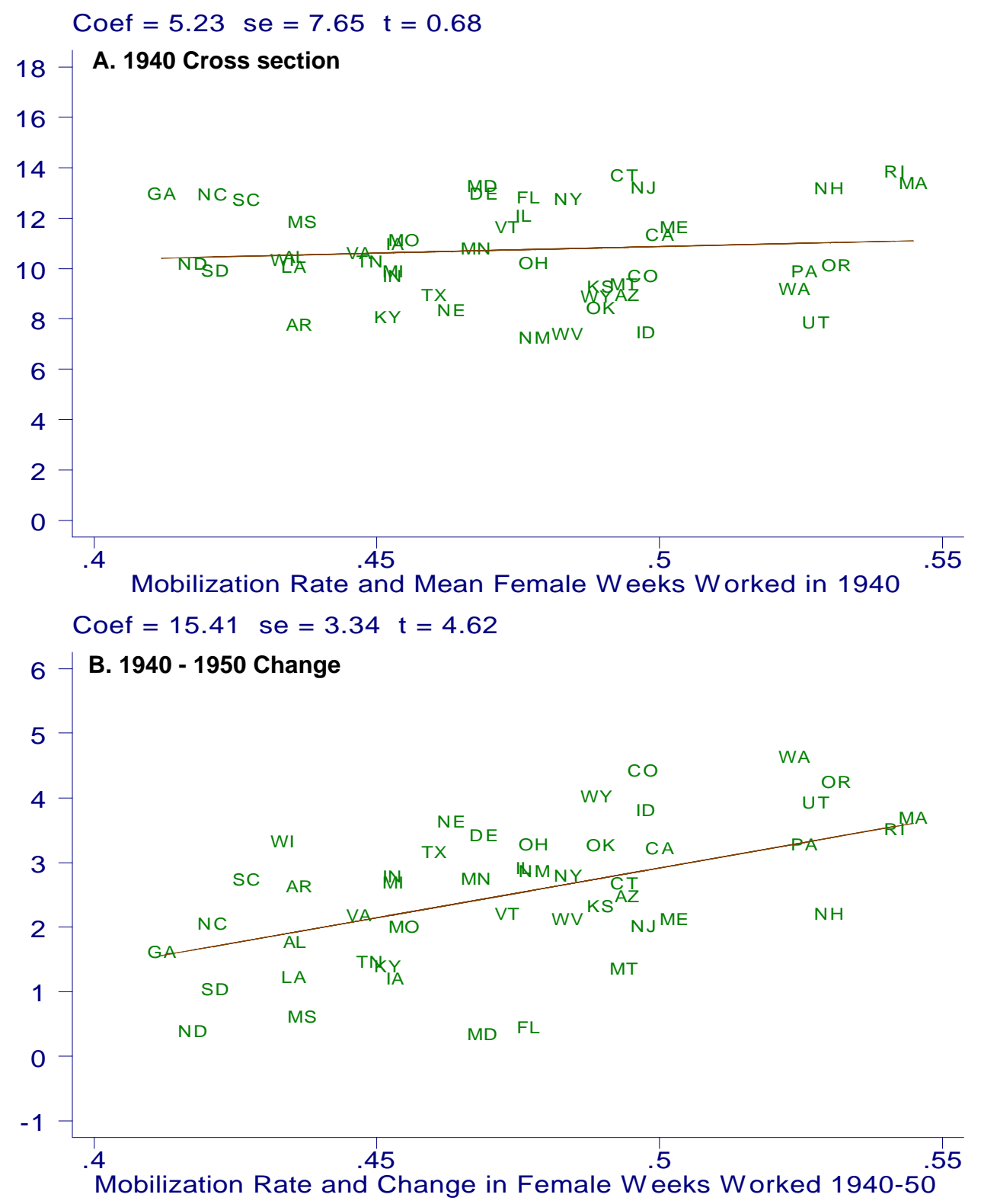

Coef $=-4.75$ se $=2.42 \mathrm{t}=-1.97$

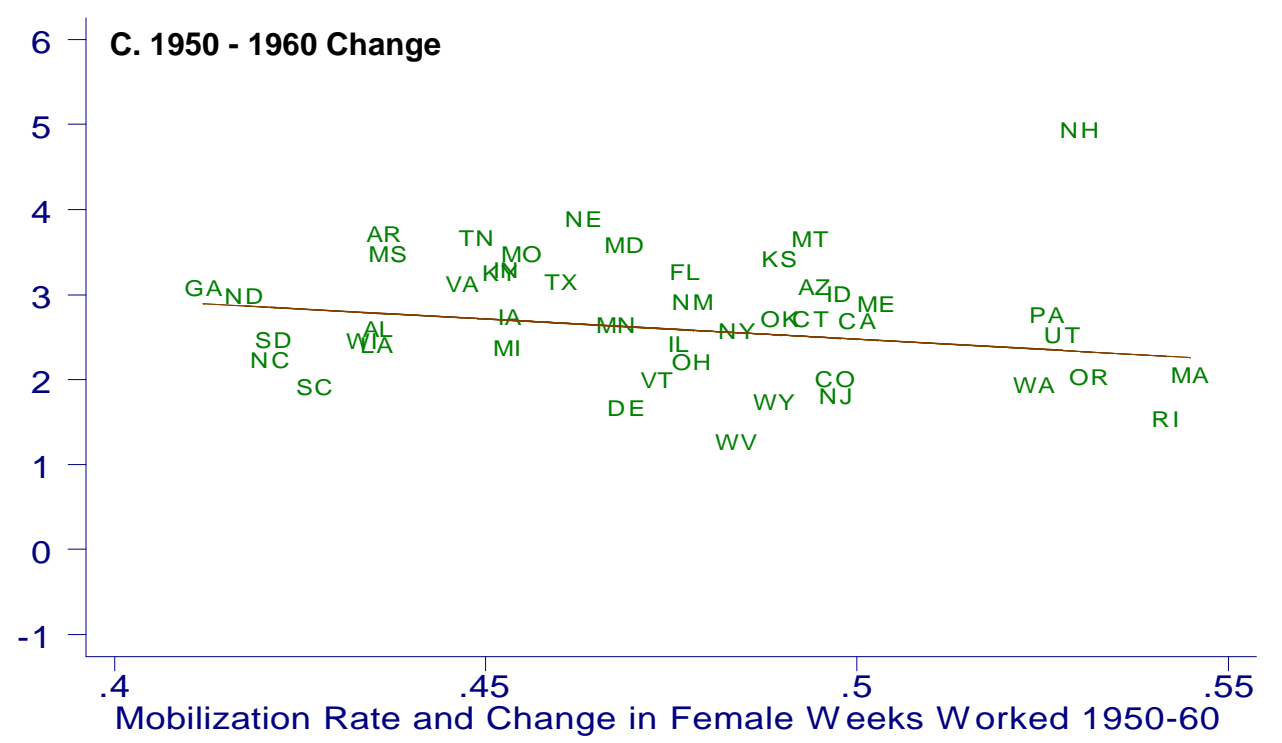

Figure 3. State WWII Mobilization Rates and Female Labor Supply, 1940 - 1960 
Delta log weekly wages

Fitted values

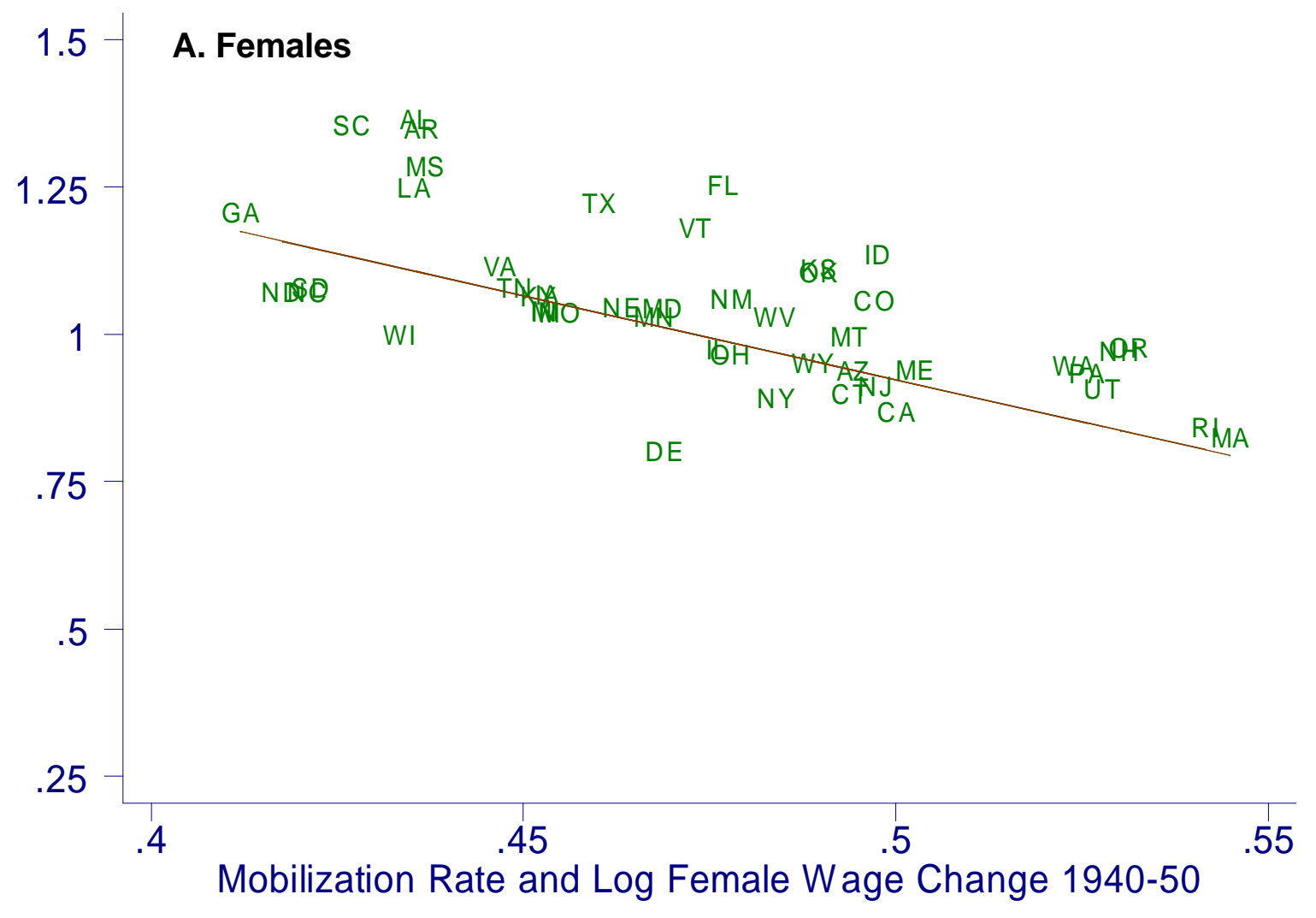

Delta log weekly wages

Fitted values

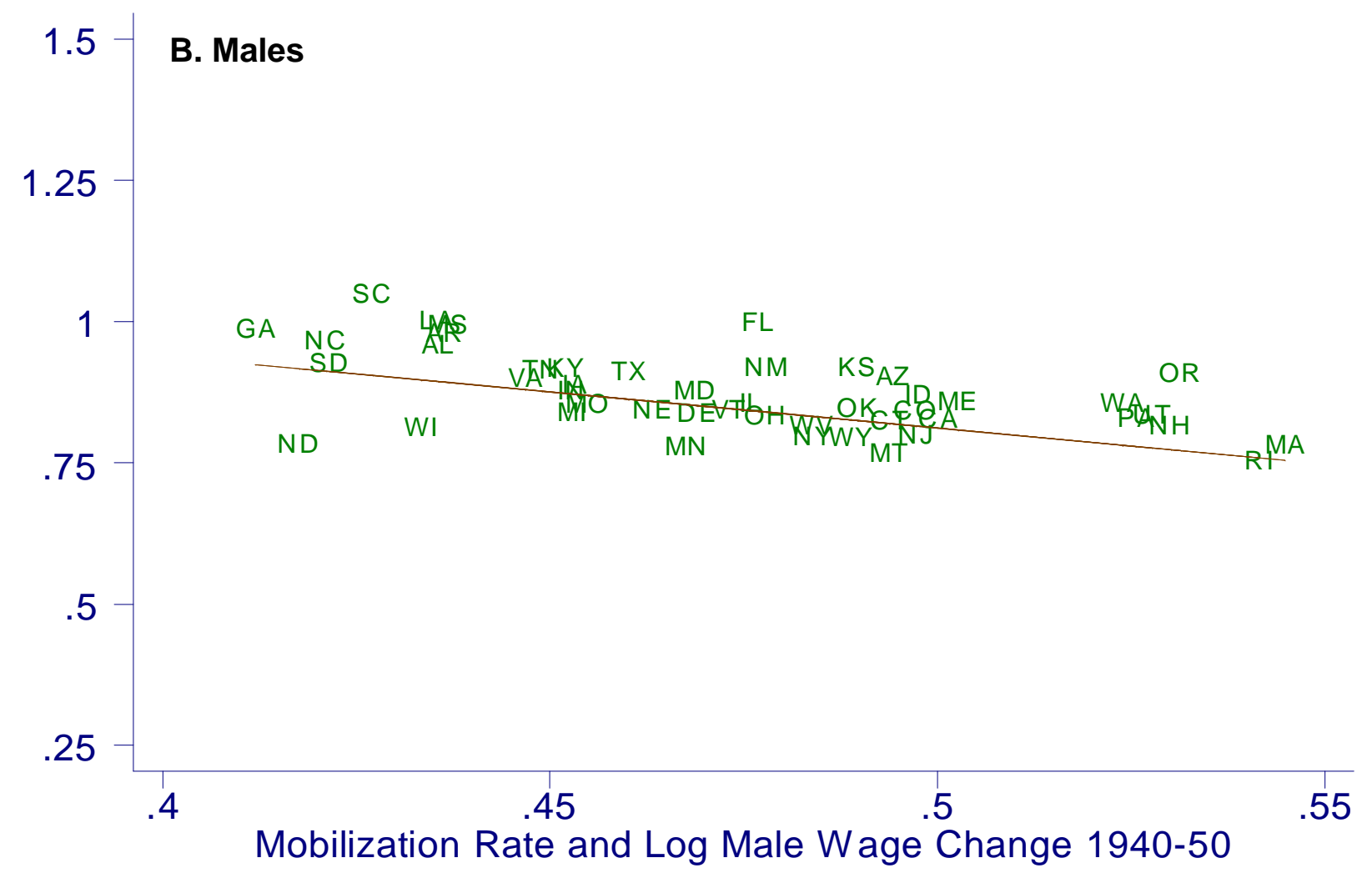

Figure 4. State WWII Mobilization Rates and Changes in Male and Female Mean Log Weekly Wages, 1940 - 1950 
Delta log weekly wages

Fitted values
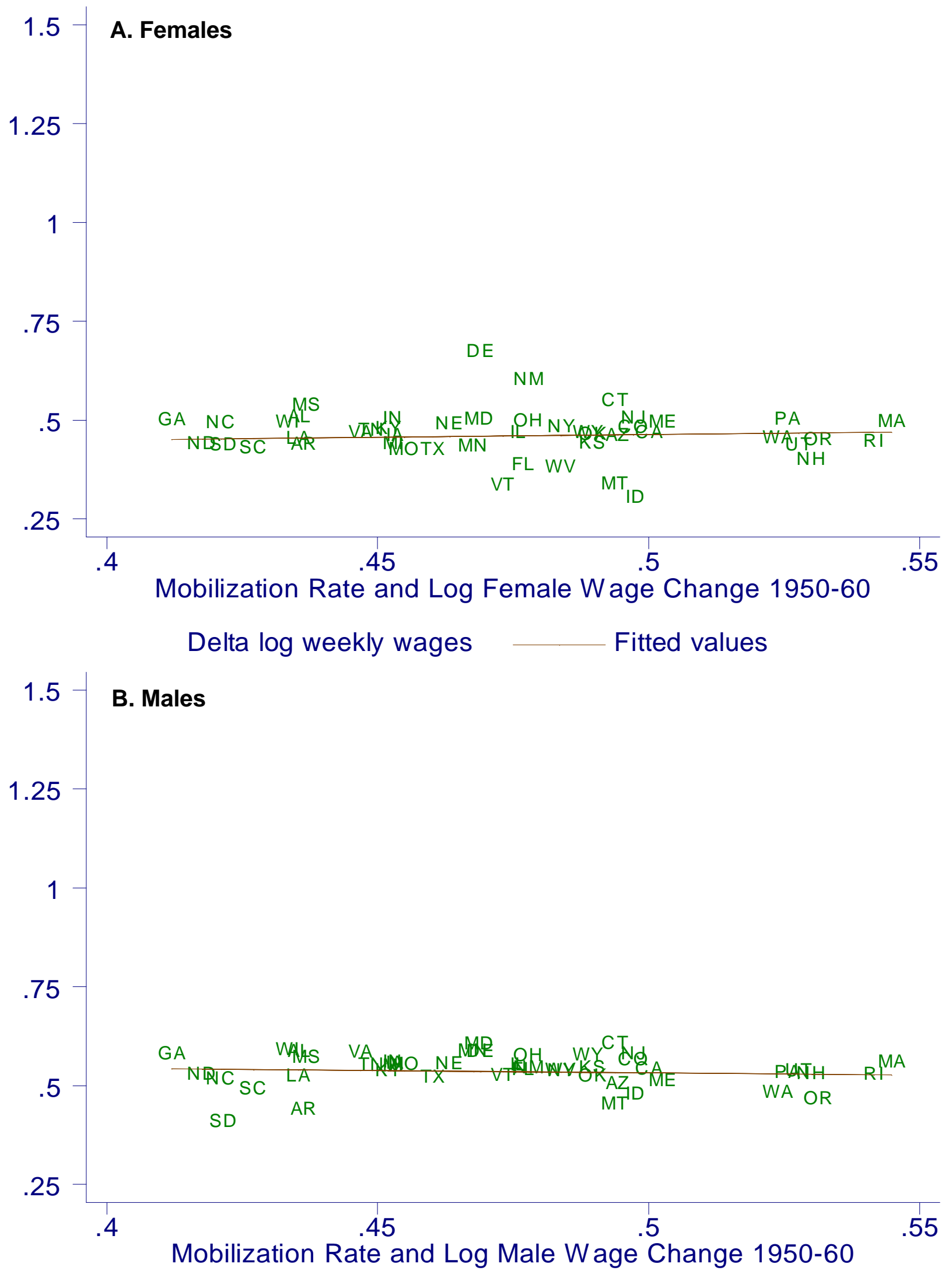

Figure 5. State WWII Mobilization Rates and Changes in Male and Female Mean Log Weekly Wages, 1940 - 1950 


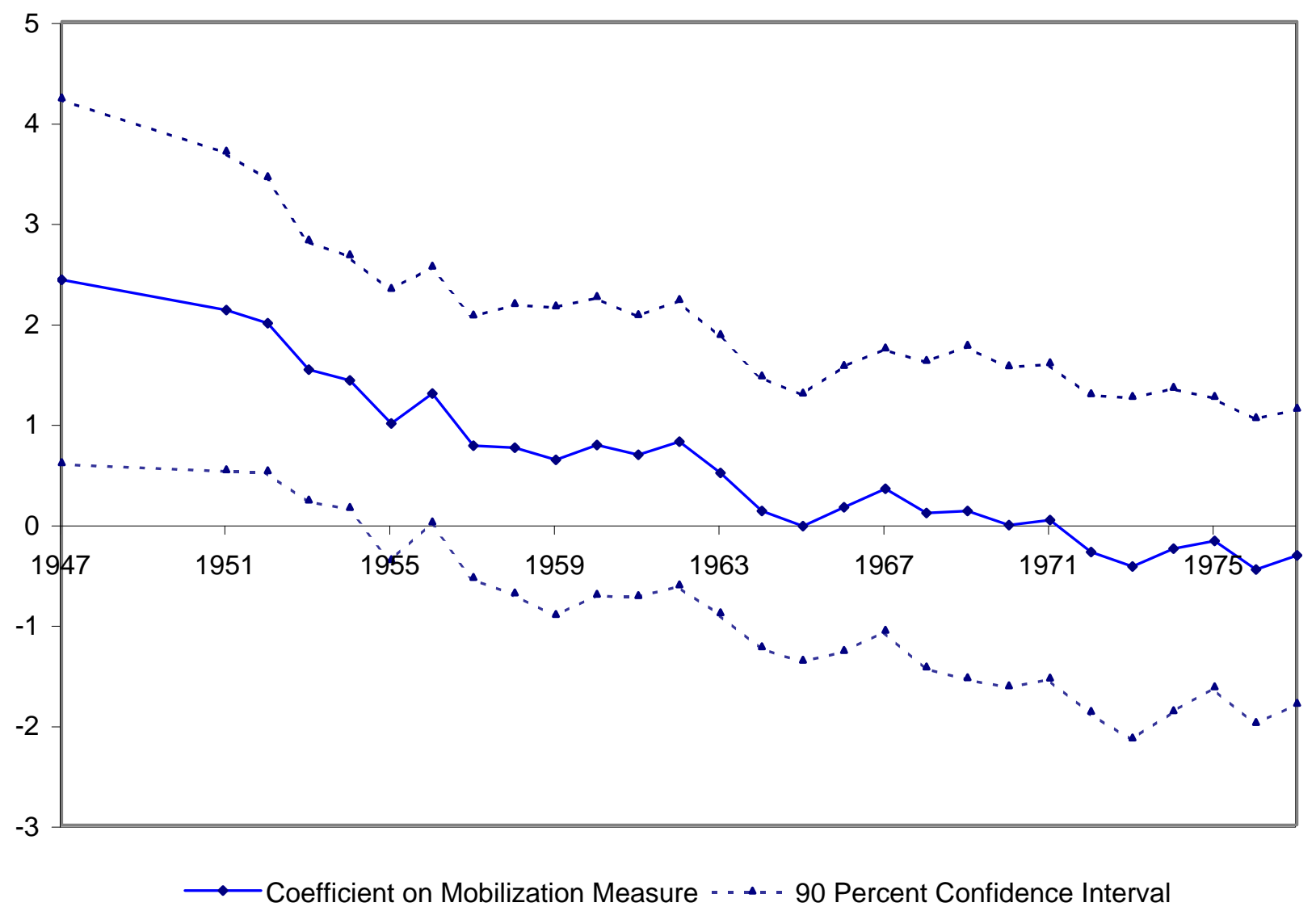

Figure 6. Estimated Impact of State WWII Mobilization Rate on Standardized Quarters Worked Annually by Women Who Were Ages 16 - 55 in 1945: 1947 - 1977. 